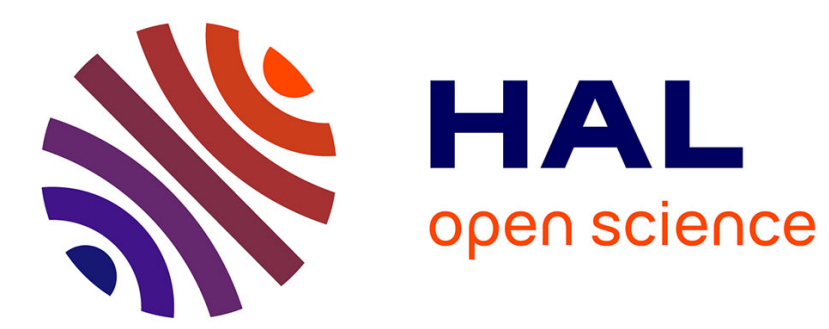

\title{
Heterogeneity and anisotropy in the lithospheric mantle
}

Andrea Tommasi, Alain Vauchez

\section{To cite this version:}

Andrea Tommasi, Alain Vauchez. Heterogeneity and anisotropy in the lithospheric mantle. Tectonophysics, 2015, 661, pp.11-37. 10.1016/j.tecto.2015.07.026 . hal-01277174

\section{HAL Id: hal-01277174 \\ https://hal.science/hal-01277174}

Submitted on 16 Jun 2021

HAL is a multi-disciplinary open access archive for the deposit and dissemination of scientific research documents, whether they are published or not. The documents may come from teaching and research institutions in France or abroad, or from public or private research centers.
L'archive ouverte pluridisciplinaire HAL, est destinée au dépôt et à la diffusion de documents scientifiques de niveau recherche, publiés ou non, émanant des établissements d'enseignement et de recherche français ou étrangers, des laboratoires publics ou privés. 
Review article published in Tectonophysics.

Please cite as: Tommasi, A. and Vauchez, A. (2015) Heterogeneity and anisotropy in the lithospheric mantle. Tectonophysics, 661:

11-37, doi: 10.1016/j.tecto.2015.07.026

\title{
Review Article
}

\section{Heterogeneity and anisotropy in the lithospheric mantle}

\author{
Andréa Tommasi *, Alain Vauchez \\ Géosciences Montpellier, Université de Montpellier E CNRS, CC 60, Place E. Bataillon, 34095 Montpellier cedex 5, France
}

Keywords:

Geodynamics

Plate tectonics

Mantle deformation

Strain localization

Olivine crystal preferred orientations

Metasomatism

\begin{abstract}
A B S T R A C T
The lithospheric mantle is intrinsically heterogeneous and anisotropic. These two properties govern the repartition of deformation, controlling intraplate strain localization and development of new plate boundaries. Geophysical and geological observations provide clues on the types, ranges, and characteristic length scales of heterogeneity and anisotropy in the lithospheric mantle. Seismic tomography points to variations in geothermal gradient and hence in rheological behavior at scales of hundreds of $\mathrm{km}$. Seismic anisotropy data substantiate anisotropic physical properties consistent at scales of tens to hundreds of $\mathrm{km}$. Receiver functions imply lateral and vertical heterogeneity at scales $<10 \mathrm{~km}$, which might record gradients in composition or anisotropy. Observations on naturally deformed peridotites establish that compositional heterogeneity and Crystal Preferred Orientations (CPOs) are ubiquitous from the $\mathrm{mm}$ to the $\mathrm{km}$ scales. These data allow discussing the processes that produce/destroy heterogeneity and anisotropy and constraining the time scales over which they are active. This analysis highlights: (i) the role of deformation and reactive percolation of melts and fluids in producing compositional and structural heterogeneity and the feedbacks between these processes, (ii) the weak mechanical effect of mineralogical variations, and (iii) the low volumes of fine-grained microstructures and difficulty to preserve them. In contrast, olivine CPO and the resulting anisotropy of mechanical and thermal properties are only modified by deformation. Based on this analysis, we propose that strain localization at the plate scale is, at first order, controlled by large-scale variations in thermal structure and in CPO-induced anisotropy. In cold parts of the lithospheric mantle, grain size reduction may contribute to strain localization, but the low volume of fine-grained domains limits this effect.
\end{abstract}

\section{Contents}

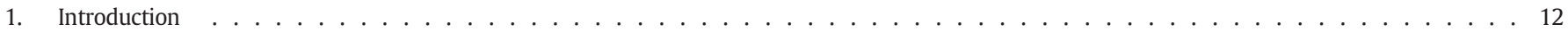

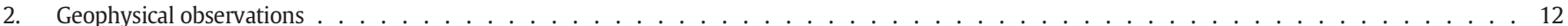

2.1. Heterogeneity in the lithospheric mantle . . . . . . . . . . . . . . . . . . . . . . . . . . . . 12

2.2. Seismic and electrical anisotropy in the lithospheric mantle . . . . . . . . . . . . . . . . . . . . . . . . . . . . . . 14

3. Geological observations: processes that form and destroy heterogeneity and anisotropy in the lithospheric mantle . . . . . . . . . . . . . . . . . . . 15

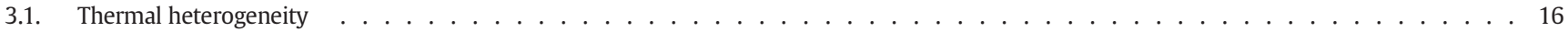

3.2. Chemical and mineralogical heterogeneity . . . . . . . . . . . . . . . . . . . . . . . . . . . 16

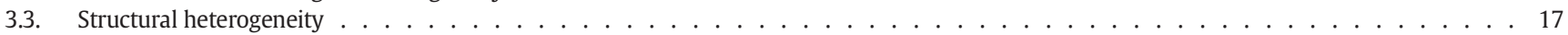

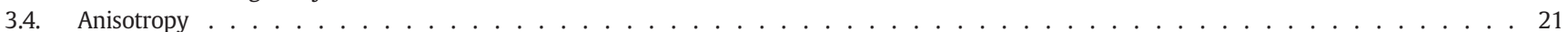

4. Consequences for the evolution of the lithospheric mantle and for plate tectonics . . . . . . . . . . . . . . . . . . . . . . . . . . . . . . 24

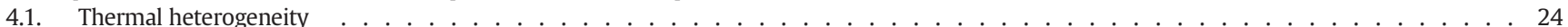

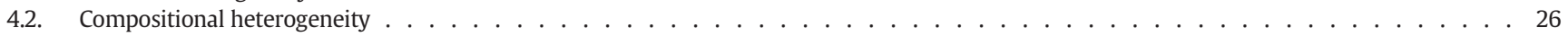

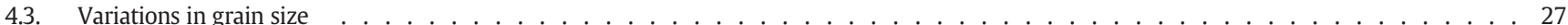

4.4. Thermo-mechanical anisotropy . . . . . . . . . . . . . . . . . . . . . . . . . . . . . . . . . . . . . . . . 28

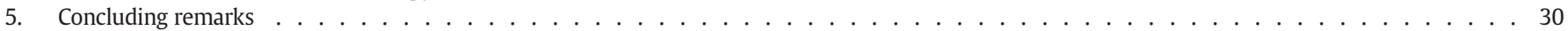

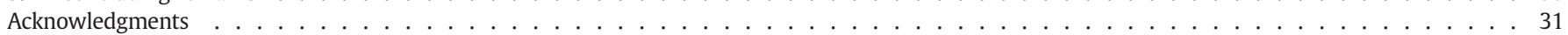

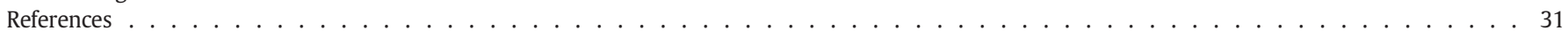

\footnotetext{
* Corresponding author.

E-mail address: andrea.tommasi@umontpellier.fr (A. Tommasi).
} 


\section{Introduction}

Tectonic plates are dominantly composed of peridotites - the lithospheric mantle. The shallowest and coldest part of this layer is, in most cases, the strongest part of the plates. It plays therefore an essential role in plate tectonics. For simplicity sake, the lithospheric mantle is usually defined as a stable, homogeneous and isotropic layer. Geophysical observations show nevertheless that the lithospheric mantle is neither homogeneous nor isotropic. Seismic tomography models highlight a strong heterogeneity in seismic velocities at depths between 50 and 150 km (e.g., Trampert and Van Der Hilst, 2005; Ritsema et al., 2011; Debayle and Ricard, 2012; Simmons et al., 2012; Obayashi et al., 2013). These velocity contrasts reflect, to the first order, lateral variations in the thermal structure of the mantle at scales ranging from tens to hundreds of $\mathrm{km}$. Seismic refraction/reflection data, receiver function analysis, or waveform modeling predict still sharper (at the scale of a few km or even less) contrasts in elastic properties, which may result from variations in composition or in the deformation fabric within the lithospheric mantle. Splitting of teleseismic shear waves and the azimuthal anisotropy of Pn and Rayleigh wave velocities indicate that seismic anisotropy is ubiquitous in the shallow mantle (e.g., Montagner, 1998; Savage, 1999; Smith and Ekström, 1999). This anisotropy implies coherent orientation of olivine crystals at scales of tens to hundreds of kilometers, formed in response to active or past deformation episodes (e.g., Nicolas and Christensen, 1987; Savage, 1999; Silver et al., 1999; Vauchez and Nicolas, 1991).

Heterogeneity and anisotropy are fundamental properties that modify the mechanical response of rocks to applied forces and thus shape the strain field. They also affect the propagation of seismic waves as well as thermal and electrical conduction. Heterogeneity arises from spatial variations in composition or physical parameters. It may be thermal, corresponding to either a lateral variation in the stationary geothermal gradient or local, transient changes of the geotherm due to advective processes or enhanced heat production. Compositional heterogeneity arises from changes in the mineralogical composition or from more subtle variations in the trace-element contents. Among the latter, only variations in the hydration state of olivine may significantly affect physical properties. Heterogeneity may also be structural, arising from a spatial variation in the microstructure of the rock, such as gradients in grain size, changes in the crystallographic or shape preferred orientations, or in the spatial arrangement of the rock-forming minerals. If any of these heterogeneities result in significant variation in the rheological properties of the lithospheric mantle, it may trigger strain localization.

Anisotropy, on the other hand, results from a regular arrangement of 'objects' with different properties, such as the atomic bonds in a crystal or, at a larger scale, the repetition of layers of materials with different composition or structure. Even if produced at the crystal scale, anisotropy may be transferred at much larger scales provided the anisotropic objects are themselves arranged in a regular way. Anisotropy of mechanical properties (and, in an indirect way, thermal properties) changes the strain field produced by an applied stress, since some directions are easier to deform than others. It may therefore produce strain localization. The scale of observation is crucial for discriminating between anisotropy and heterogeneity. If the periodicity of the variation in physical parameters is much smaller than the observation length scale, the medium is seen as homogeneous, but anisotropic. On the other hand, if the observation length scale is similar to the one at which the changes in physical parameters occur, the medium will be described as heterogeneous.

In this article, we review the geophysical observations that constrain heterogeneity and anisotropy in the lithospheric mantle. Then, based on observations on peridotite massifs and xenoliths, we discuss the processes that may produce and destroy heterogeneity and anisotropy in the lithospheric mantle and try to define characteristic spatial and temporal scales for the various types of heterogeneity and anisotropy in the lithospheric mantle. Finally, the geodynamical consequences of the different types of heterogeneity and anisotropy are analyzed.

\section{Geophysical observations}

\subsection{Heterogeneity in the lithospheric mantle}

Seismology samples the elastic properties of the lithospheric mantle over a large range of scales, from the global distribution of seismic velocities to local contrasts in seismic properties producing seismic conversions and reflections. It is therefore our best tool to 'map' heterogeneity in the lithospheric mantle. However, relating the observed contrasts in elastic properties to variations in temperature, composition, or deformation is not always straightforward.

Global seismic tomography models highlight variations of $\pm 7 \%$ for $\mathrm{S}$ waves and $\pm 3 \%$ for $\mathrm{P}$ waves between 50 and $200 \mathrm{~km}$ depth (e.g., Debayle and Ricard, 2012; Obayashi et al., 2013; Ritsema et al., 2011; Simmons et al., 2012; Trampert and Van Der Hilst, 2005). These large-scale variations in seismic velocities correlate well with the surface heat flow distribution at the global scale (cf. the recent compilation by Davies, 2013 and the global heat flow database: http://www. heatflow.und.edu/). This correlation supports that global tomography models image, to the first order, lateral variations in the thermal structure of the plates, that is, thermal heterogeneity in the lithospheric mantle. They provide consistent 3D representations of cratonic domains, major continental rifts, and volcanic arcs (Fig.1a).

Depletion in Fe of residual mantle rocks due to partial melting (or enrichment due to metasomatism) may also enhance (reduce) seismic velocities (James et al., 2004; Jordan, 1975, 1979; Tommasi et al., 2004). Compositional heterogeneity is not often invoked to explain velocity anomalies at the scale of hundreds to thousands of $\mathrm{km}$, because petrological processes have usually smaller characteristic spatial length-scales (cf. Section 3.2). However, in cratonic roots, low temperatures and Fe-depletion add up to produce high seismic velocities, but low densities (Baptiste and Tommasi, 2014; James et al., 2004; Jordan, 1979). The opposite effects of Fe-depletion on seismic velocity and density make the joint analysis of gravity and seismic data a powerful tool for discriminating between thermal and compositional heterogeneity in the lithospheric mantle (e.g., Afonso et al., 2008; Tesauro et al., 2014).

Regional scale tomography models better define the geometry of the velocity anomalies, as, for instance, the broadening and intensification of the low anomaly associated with the East African rift approaching the Afar region (e.g., Bastow et al., 2008). They also provide evidence for smaller wavelength (tens to hundreds of $\mathrm{km}$ ) variations in seismic velocities superposed to the large-scale structure. Such variations in seismic velocities were imaged, for instance, in the lithospheric mantle beneath Australia (Fig. 1b; Fishwick et al., 2005) and the Baltic shield (Fishwick et al., 2005; Pedersen et al., 2013). They might have a compositional origin, as suggested for the relatively lower velocities observed beneath the Bushveld complex in the Kaapvaal craton (Fouch et al., 2004; James et al., 2001). Small-scale heterogeneities were also imaged in the broad low velocity domain beneath the Afars, where they were interpreted as due to the presence of melts (Hammond et al., 2014). Analysis of $\mathrm{Vp} / \mathrm{Vs}$ ratios obtained from joint P- and S-wave tomography may further constrain compositional heterogeneity in the lithospheric mantle. For instance, the association of low Pn velocities and low Vp/ Vs ratios in the mantle lid beneath Sierra Nevada implies a compositional origin for the observed velocity reduction (Buehler and Shearer, 2014).

Seismic refraction/reflection data, receiver function analysis, and waveform modeling point to sharp contrasts (at scales of a few $\mathrm{km}$ or even less) in elastic properties within the lithospheric mantle. Shallowly dipping reflectors have been observed at various depths in the lithospheric mantle. The best studied among these reflectors are 


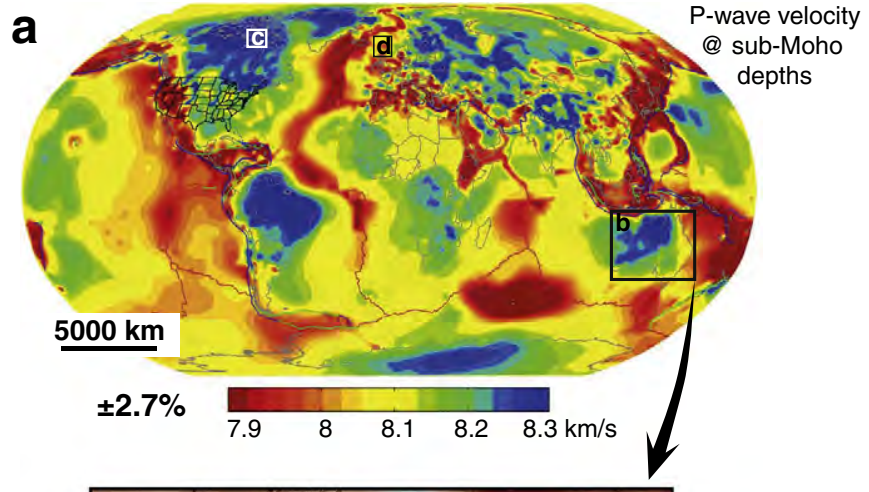

b
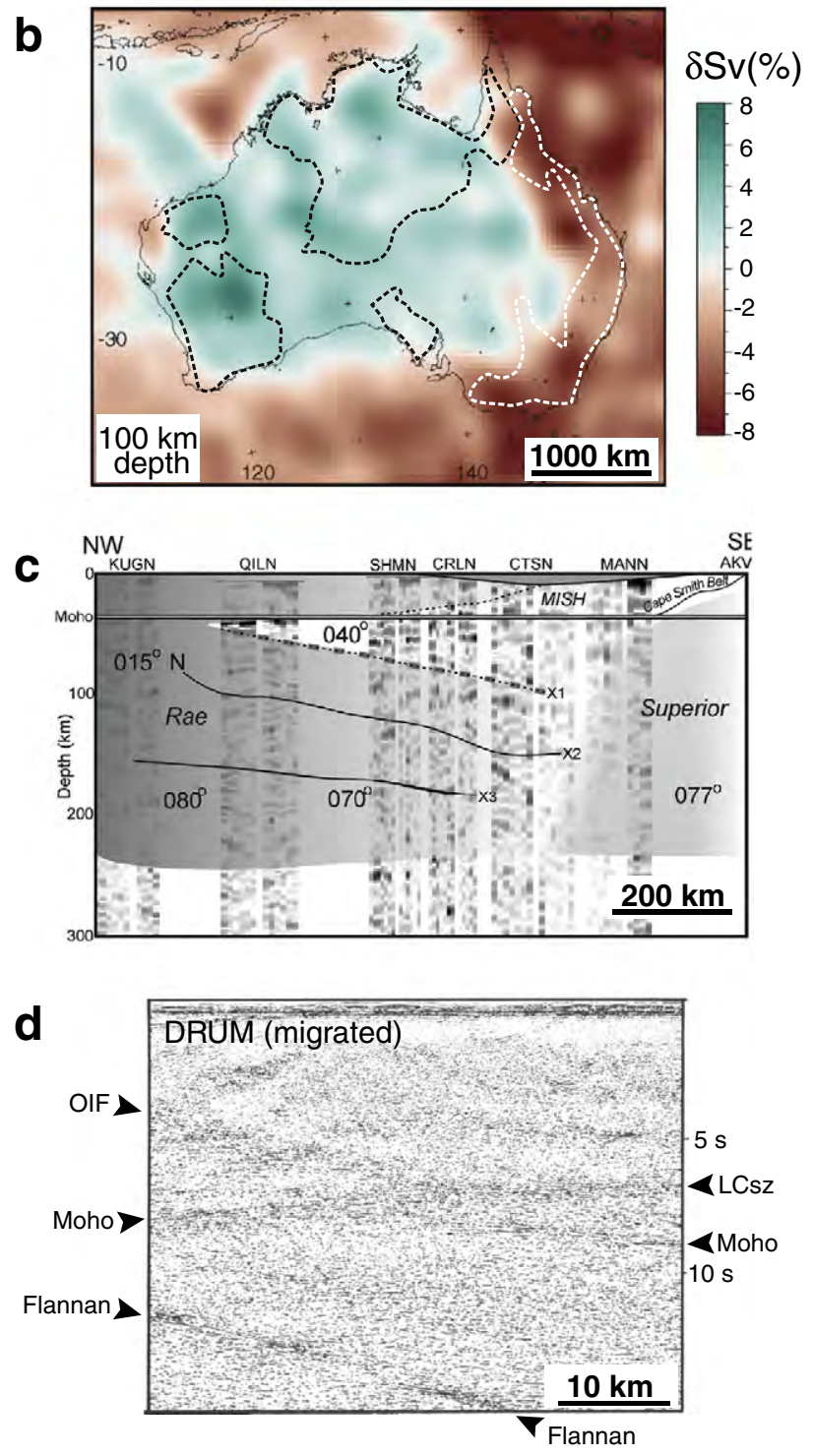

Fig. 1. Seismological observations of heterogeneity in the mantle at different spatial scales. (a) P-wave velocity variations at sub-Moho depths in the global P-wave tomography model by Simmons et al. (2012). (b) S-wave velocity variations at $100 \mathrm{~km}$ depth in a regional surface-wave tomography model of Australia (Fishwick et al., 2005). The major contrast is observed between the Paleozoic domains of eastern Australia (outlined by a white dashed line) and the domains characterized by Archean or Proterozoic crust exposures (outlined by black dashed lines), but significant variations in the intensity of the anomalies exist even within each of these domains. (c) Intralithospheric mantle discontinuities $(\mathrm{X} 1, \mathrm{X} 2, \mathrm{X} 3)$ inferred from coupled receiver function and SKS splitting data analysis in the Rae craton, northern Canada (Snyder et al., 2013). (d) The Flannan mantle reflector sampled by the DRUM reflection profile in the North Sea; OIF: Outer Island Fault, LCsz: low-angle lower crust shear zone (Reston, 1993). the Flannan reflector in the shallow mantle beneath the North Sea (Reston, 1990) and the " 8 ' seismic discontinuity", which is marked by strong scattered reflections from a low velocity zone below ca. $100 \mathrm{~km}$ depth in North America and Eurasia (Thybo and Perchuc, 1997). Midlithospheric velocity discontinuities (Fig. 1c) are also often detected in PS receiver function data, in particular beneath cratons (e.g., Abt et al., 2010; Bostock, 1997, 1998; Ford et al., 2010; Rychert and Shearer, 2009; Wittlinger and Farra, 2007). Finally, scattering of guided waves in old oceanic lithosphere domains might be explained by a layered structure with dimensions of $\sim 10 \mathrm{~km}$ in the horizontal direction and $<1 \mathrm{~km}$ in the vertical direction in at least the top $40 \mathrm{~km}$ of the plate (Furumura and Kennett, 2005; Shito et al., 2013).

The physical causes for such sharp changes in elastic properties are, however, still poorly constrained. Both compositional gradients and changes in anisotropy due to superposition of structures formed in response to different flow fields have been proposed, but, if the range of variation of composition and seismic anisotropy is constrained based on observations in natural peridotites, the resulting contrast in seismic velocities is often too low to explain the seismological observations. Alternative interpretations are the presence of small melt fractions or variations in the hydration degree in the mantle. Attenuation should be more sensitive to these two parameters, as well as to grain size (Aizawa et al., 2008; Jackson et al., 2002). Attenuation models detailing the structure of the lithospheric mantle are, however, still rare. Most studies focus on subduction zones, with significant attenuation observed in the wedge and beneath the arc (Abers et al., 2014). The lithospheric mantle is usually characterized by low attenuation, but some variation in both Qp and Qs within the subcontinental lithospheric mantle is proposed in attenuation tomography models in the Himalayas (Sheehan et al., 2014).

Measurement of electrical conductivity variations using long period magnetotelluric data is another tool to probe the deep Earth. However, the sensitivity of this method in the lithospheric mantle is limited by the fact that the latter is a resistive layer sandwiched between the conductive lower crust and asthenosphere (Jones, 1999). Lateral and vertical variations in electrical conductivity by up to 2 orders of magnitude were nevertheless mapped in the Slave and Kaapvaal cratonic lithosphere (Evans et al., 2011; Jones et al., 2001). Large lateral variations in electrical conductivity have also been observed beneath plate-scale shear zones with ages ranging from Archean to Cenozoic, such as the Great Slave and Snowbird tectonic zones in Canada (Eaton et al., 2004; Jones et al., 2002), the Pernambuco shear zone in northeast Brazil (Santos et al., 2014), the North Pyrenean fault (Pous et al., 2004), and the Tien Shan fault in the Himalaya (Bielinski et al., 2003). Yet the electrical conductivity signatures vary. High conductivity domains were imaged beneath the North Anatolian fault (Kaya et al., 2013), the Red River fault system (Pham et al., 1995), and beneath suture zones in Asia and North America (Dong et al., 2014; Meqbel et al., 2014). In contrast, high resistivity is associated with the Great Slave shear zone up to $50 \mathrm{~km}$ depth (Yin et al., 2014) and with a Neoproterozoic collisional suture in northeast Brazil (Padilha et al., 2014).

Relating variations in electrical conductivity to thermal or compositional heterogeneity in the lithospheric mantle remains difficult. Electrical conductivity of mantle rocks depends exponentially on temperature (Bradley et al., 1964; Constable et al., 1992). It depends weakly on the mineralogical composition, but it might (or not) be highly sensitive to hydrogen incorporated as a trace element in olivine (there is no consensus in the experimental data; cf., Poe et al., 2010; Yoshino and Katsura, 2013; Dai and Karato, 2014). Electrical conductivity also depends on oxygen fugacity (Duba et al., 1974) and on the presence and interconnectivity of minor, but highly conductive phases, like graphite, sulfides, or melts along grain boundaries (Ducea and Park, 2000; Jones et al., 2001; Pommier and Garnero, 2014; Sifré et al., 2014; Wang et al., 2013a). Joint seismic and magnetotelluric surveys may help discriminating between these effects, since the sensitivities of seismic and electrical properties to each parameter differ. 


\subsection{Seismic and electrical anisotropy in the lithospheric mantle}

A large range of seismological data images the anisotropy of elastic deformation in the lithospheric mantle. Two types of seismic anisotropy can be measured: polarization anisotropy and azimuthal or propagation anisotropy (Crampin et al., 1984). The first results from a variation in seismic velocities as a function of the polarization direction. It is revealed, for instance, by the splitting of a shear wave into two orthogonally polarized shear waves when it crosses an anisotropic medium. The second type is defined by the variation of seismic wave velocity with the direction of propagation. There is a large consensus, based on surface wave (e.g., Gung et al., 2003; Montagner and Kennett, 1996) and petrophysical data (cf. review in Mainprice, 2007), that most of the measured anisotropy is located in the upper $250 \mathrm{~km}$ of the mantle, that is, in the lithospheric mantle and in the asthenosphere. However, deconvolving the contributions of these two layers is not straightforward.

Anisotropic tomography models based on surface wave data have been used since the 70s to map anisotropy at different depths in the Pacific (Forsyth, 1975) and, since the 80s, at the global scale (e.g., Nataf et al., 1984). Recent global Rayleigh wave tomographic models show strong anisotropy (up to $4 \%$ ) with marked variations in both intensity and orientation in the upper $150 \mathrm{~km}$ of the mantle (e.g., Auer et al., 2014; Debayle and Ricard, 2013). Regional models highlight marked variations in the Rayleigh wave fast propagation directions between the lithospheric mantle and the asthenosphere in Australia (Debayle and Kennett, 2000), North America (Deschamps et al., 2008; Gung et al., 2003), and Aegean (Endrun et al., 2011), or within the lithospheric mantle in cratonic regions (Yuan and Romanowicz, 2010). However, these models have low resolution (hundreds of $\mathrm{km}$ ) and may suffer of a tradeoff between isotropic velocity anomalies and anisotropy.

The analysis of the splitting of teleseismic shear waves, such as SKS, PKS, and SKKS, is the most direct measurement of the seismic anisotropy (Silver and Chan, 1988; Vinnik et al., 1984). Teleseismic shear wave splitting data are 'point' measurements; they probe the anisotropy within a 'conic' volume with a radius ranging from ca. $50 \mathrm{~km}$ at $50 \mathrm{~km}$ depth to ca. $100 \mathrm{~km}$ at $250 \mathrm{~km}$ depth beneath the station (Alsina and Snieder, 1995; Rümpker and Ryberg, 2000). The global coverage depends therefore on the deployment of seismometers. It has been significantly enhanced by the multiplication of seismic deployments in the last decade and by the development of automated measurement techniques (e.g., Teanby et al., 2004). Recent compilations (Wuestefeld et al., 2009; Becker et al., 2012; Walpole et al., 2014) highlight nevertheless the very sparse sampling of the southern hemisphere continents and, hence, of Gondwana-derived terranes (Fig. 2). Analysis of these data also reveals that seismic anisotropy is the rule, rather than the exception. Delay times between the fast and slow split waves have a log normal distribution with mean value of $1.6 \mathrm{~s}$ (Walpole et al., 2014). A very small number of stations in varied geodynamic environments are apparently isotropic (5-24 within a total of 2016 analyzed stations, depending on the criteria used for defining the null measurements; Walpole et al., 2014). Moreover, this apparent isotropy most probably results from small-scale lateral or vertical variations in anisotropy or to particular fabrics (horizontal foliations with [010]-fiber olivine CPO) in the lithospheric mantle (Vauchez et al., 2005; Bascou et al., 2008).

The main shortcoming of shear-wave polarization anisotropy measurements is the lack of vertical resolution. They integrate the anisotropy along a quasi-vertical path from the core-mantle boundary to the surface. Determining the depth at which splitting occurs requires excellent back-azimuthal coverage (Rümpker et al., 1999; Silver and Savage, 1994), a condition not fulfilled for most of the Earth surface (cf. Fig. 8 of Becker et al., 2012). In stations where this condition is fulfilled, the observations are often better explained by two superposed anisotropic layers, one corresponding to the lithosphere and the other to the asthenosphere, as for instance beneath the San Andreas fault in California (e.g., Bonnin et al., 2010; Silver and Savage, 1994). In addition, several experiments have revealed sharp rotations of the fast split shear wave polarization between stations spaced by a few tens of kilometers (e.g., Bastow et al., 2008; Heintz et al., 2003), a distance that, considering the Fresnel zone of the split waves, requires that the main contribution to the measured anisotropy is in the lithospheric mantle (Alsina and Snieder, 1995).

The analysis of azimuthal variations of P-wave velocity has been extensively used to characterize the anisotropy of the lithospheric mantle since the pioneering analysis of active source experiments in the Pacific ocean by Hess (1964). Many techniques have been used, including refraction data (e.g., Fuchs, 1977) and P-wave residuals (Babuska et al., 1984), but most studies focused on Pn waves, which sample specifically the shallow lithospheric mantle (e.g., Bamford, 1977; Buehler and Shearer, 2014; Calvert et al., 2000; Fuchs, 1977; Hearn, 1996; Hirn, 1977; Judenherc et al., 2003; Smith and Ekström, 1999). More recently, anisotropic tomographic inversions of P-wave velocities have been applied to continental domains. Sharp variations in the fast propagation direction and up to 3\% azimuthal anisotropy were, for instance, modeled at lithospheric depths beneath North America (Huang and Zhao, 2013). Seismic anisotropy in the shallow lithospheric mantle is also supported

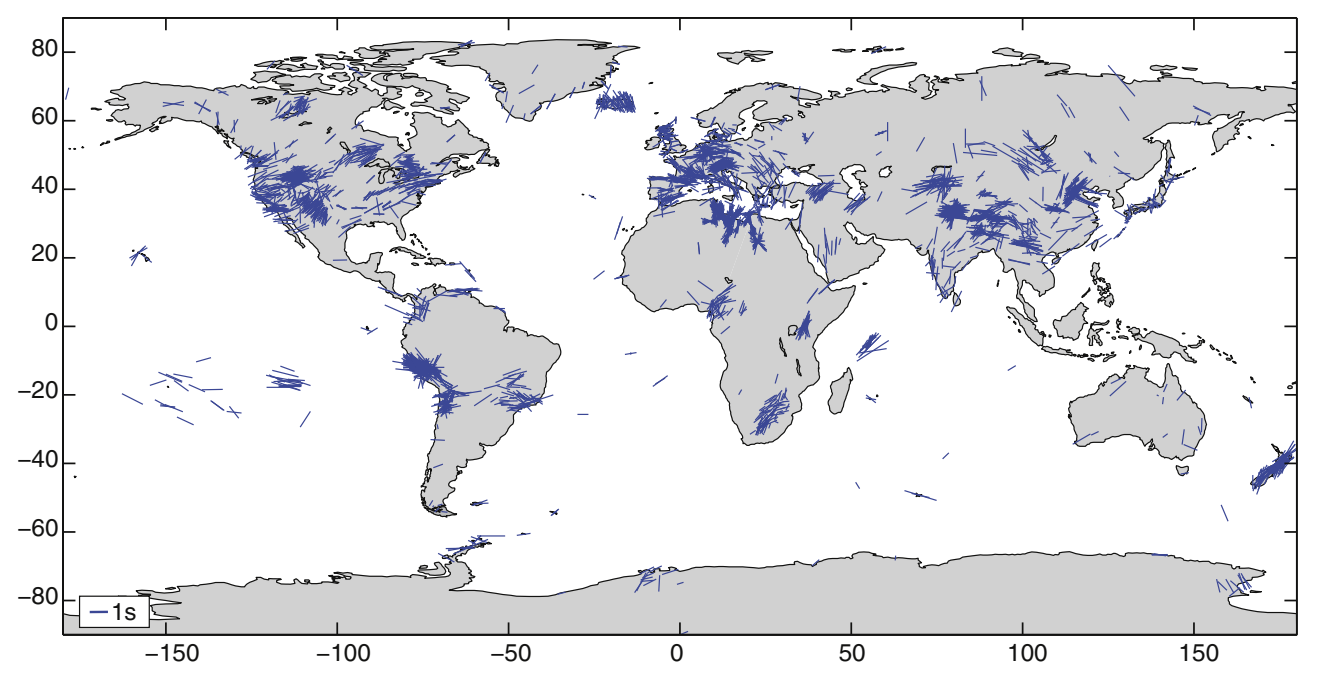

Fig. 2. Global compilation of teleseismic S-wave splitting data based on the open-access SplittingDataBase at http://splitting.gm.univ-montp2.fr/DB/ (Wuestefeld et al., 2009). 
by coupled inversion of Pn and Sn velocities, which show a clear azimuthal dependence of both Pn and Sn velocities with up to 5\% azimuthal anisotropy in the shallow lithospheric mantle beneath western North America (Buehler and Shearer, 2014). These data clearly sample the lithospheric mantle. Their major shortcoming is the tradeoff between anisotropy and isotropic velocity anomalies, which can only be resolved if an ideal backazimuthal coverage is available.

Anisotropic receiver functions provide ideally high-resolution (tens of $\mathrm{km}$ ) imaging of anisotropy both vertically and horizontally (Bostock, 1997; Kosarev et al., 1984; Levin and Park, 1997). This method has, for instance, provided evidence for the presence of multiple dipping anisotropic layers within the Slave craton (Bostock, 1997) and beneath the Hudson Bay (Snyder et al., 2013). However, it requires a large number of earthquake recordings and a good back-azimuthal illumination. Therefore, long-term deployment of dense arrays and high quality data are needed. It also needs a simple crustal structure, so that multiples of crustal reflectors do not interfere with mantle reflectors (Farra and Vinnik, 2000).

An alternative for characterizing the depth variation of anisotropy is the joint analysis of multiple datasets. In many places, as for instance in the Betic Cordillera in southern Spain (Buontempo et al., 2008; Calvert et al., 2000; Diaz et al., 2010), in the Hercynian belt in Brittany (Judenherc et al., 2003), and beneath the Alpine fault in New Zealand (Scherwath et al., 2002), the direction of fast propagation of Pn-waves is parallel to the polarization direction of fast split S-waves (Fig. 3). This supports that both datasets sample anisotropy in the lithospheric mantle though SKS splitting may also include deeper contributions. Further steps in this direction are joint inversions. Inversion of long-period seismic waveforms constrained by teleseismic splitting data highlights, for instance, a marked change in fast propagation direction of Rayleigh waves both within the North American craton (at depths that vary laterally from 50 to $160 \mathrm{~km}$ ) and at its base (Yuan and Romanowicz, 2010). A layered anisotropic structure has also been proposed for the Kalahari craton based on the joint analysis of S-receiver functions and surface-wave anisotropy (Sodoudi et al., 2013). Joint inversion of Pwave receiver functions and SKS particle motions also allows highresolution measurement of anisotropy both laterally and vertically (Vinnik et al., 2007). However, similarly to 'traditional' anisotropic receiver functions, this type of analysis depends on a good azimuthal illumination.

Magnetotelluric (MT) surveys are another potential tool to probe anisotropy in the lithospheric mantle. Anisotropic electrical conductivity in the lithospheric mantle with a fast conduction direction subparallel to the polarization of the fast split S-wave and to the tectonic trend has been proposed, for instance, beneath the Grenville front (Sénéchal et al., 1996), the Great Slave shear zone (Eaton et al., 2004), the

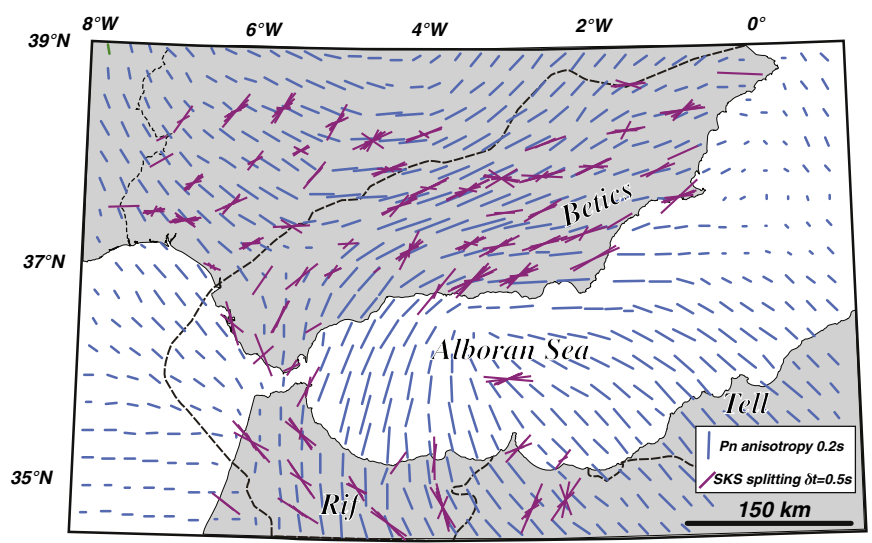

Fig. 3. Pn anisotropy (Calvert et al., 2000) and SKS splitting data (Buontempo et al., 2008 Diaz et al., 2010) in the Betic Cordillera, southern Spain. Parallelism between the fast propagation direction of Pn waves and the orientation of the polarization plane of the fast split S-wave supports seismic anisotropy within the lithospheric mantle.
Appalachians (Wannamaker et al., 1996), the Neoproterozoic belts of southeastern Brazil (Padilha et al., 2006), and the Variscan belt in central Germany (Gatzemeier and Moorkamp, 2005). In contrast, in the Kaapvaal lithospheric mantle, inferred fast conduction directions are oblique to the polarization of the fast split S-waves (Hamilton et al., 2006). The ratio between the highest and lowest conductivities attains 100 in Germany (Gatzemeier and Moorkamp, 2005), but is generally $<10$. A major difficulty in these measurements is that azimuthal variation in the MT response may also result from larger-scale variations in electrical conductivity (heterogeneity). For instance, recent reexamination of MT data in the Grenville concluded that the observed signal records extension of the resistive Archean lithosphere beneath the Grenville front rather than conductivity anisotropy in the lithospheric mantle, which is constrained to be $<10 \%$ (Adetunji et al., 2015).

The physical origin of electrical conductivity anisotropy in the lithospheric mantle is also strongly debated. The common subparallelism between fast S-wave polarization and fast conductivity directions suggests that both anisotropies are produced by deformation. Different processes have been proposed, from preferred orientation of graphite films along grain boundaries in foliated peridotites (Ji et al., 1996) to anisotropic hydrogen diffusion in olivine with faster diffusion parallel to [100] (e.g., Gatzemeier and Tommasi, 2006). All models have limitations. Experimental data on the electrical conductivity in hydrated olivine crystals are discordant; some propose that, at mantle temperatures $\left(>700^{\circ} \mathrm{C}\right.$ ), anisotropy is very low (Poe et al., 2010; Wang et al., 2006; Yoshino et al., 2009), while others point to high anisotropy, with fastest conduction parallel to [100] (Dai and Karato, 2014). Recent electrical conductivity measurements on previously deformed, dry, melt-free synthetic olivine aggregates record an enhancement by a factor 10 in electrical conductivity parallel to the preexisting shear direction relatively to undeformed samples (Pommier et al., 2015). This anisotropy is more than three times the one observed in dry olivine crystals at the same conditions, what lead Pommier et al. (2015) to propose that the conductivity enhancement results from faster conduction along preferentially aligned grain boundaries. Yet, shape preferred orientations in naturally deformed peridotites are too weak (average aspect ratios are usually < 2; e.g., Warren et al., 2008; Frets et al., 2014; Tommasi and Ishikawa, 2014) to explain the strong anisotropies inferred from MT data by higher conductivity (due to conductive phases like graphite or other processes) along aligned grain boundaries.

\section{Geological observations: processes that form and destroy heterogeneity and anisotropy in the lithospheric mantle}

The study of peridotite xenoliths and massifs allows characterizing the types and ranges of heterogeneity and anisotropy that actually exist in the mantle; it is therefore essential for constraining the interpretation of geophysical data. Analysis of the variation of average compositions of peridotites from different geodynamic settings determines the possible compositional contribution to large-scale seismic anomalies. Data from xenolith suites and peridotite massifs highlight that compositions vary at scales much smaller than those sampled by geophysical methods. Petrostructural mapping of peridotite massifs constrains the relative proportions and spatial arrangements of the different rock types. It also provides evidence for another type of heterogeneity: variations in the orientation of the deformation structures and in grain size. Last, but not least, the study of mantle peridotites brings information on the thermal, compositional, and structural evolutions through time and space. It allows therefore unraveling the processes that control the formation and destruction of heterogeneity and anisotropy in the lithospheric mantle.

This analysis is nevertheless limited by the size of the samples, which spans from a few $\mathrm{cm}^{3}$ for a xenolith to hundreds of $\mathrm{km}^{2}$ for the largest peridotite massifs, like Ronda in southern Spain or Josephine in the western USA. The data are also patchy, since the transport of mantle rocks to the surface depends on eruption of mantle-derived magmas 
with fast ascent rates or on tectonic processes leading to emplacement of mantle slivers into the crust. Peridotite massifs sample essentially the lithospheric mantle in the vicinity of active plate boundaries. The interior of the plates is only sampled by xenoliths. Another question is whether these rocks sample the lithospheric mantle or the asthenosphere. As the extraction of xenoliths implies in diking, at the time of extraction these rocks were most probably part of the lithospheric mantle, which is colder and more rigid than the asthenosphere and therefore more prone to be fractured when submitted to high fluid pressures. However, xenoliths with asthenospheric geochemical signatures are observed in some volcanic localities (e.g., Chesley et al., 1999). In fact, although most of the lithosphere is in steady state, with an equilibrium thickness and thermal structure, phenomena like continental rifting show that the lithosphere-asthenosphere boundary is not fixed through time. It can move upwards (downwards) in response to heating (thermal relaxation and cooling), melt percolation, and deformation. Different features related to the LAB migration are recorded in peridotite massifs, such as refertilisation by percolating melts in Lherz (Le Roux et al., 2007), partial melting of a previous lithospheric mantle in Ronda (Lenoir et al., 2001; Vauchez and Garrido, 2001), or thinning of the lithospheric mantle by extensional shear zones in Zabargad, Beni Bousera, Lanzo (Frets et al., 2014; Kaczmarek and Tommasi, 2011; Nicolas et al., 1987)

\subsection{Thermal heterogeneity}

In stable domains, the temperature field in the lithospheric mantle is essentially controlled by the heat flow from the convective mantle, which depends on the vigor of the convective system. This heat flow is higher beneath thin lithosphere and may be enhanced by smallscale convection at the base of the plates (Davaille and Jaupart, 1993; Doin et al., 1996). Temperatures in the shallow lithospheric mantle also depend on the efficiency of heat dissipation through the crust and, hence, on the crustal thickness and heat production. These parameters are controlled by plate tectonic processes (deformation and magmatism) and by erosion; they vary with characteristic times of 300-400 m.y. (Vitorello and Pollack, 1980).

Time scales for re-equilibration of the geotherm in response to changes in the heat flow from the convective mantle are of several tens to hundreds of m.y. due to the low thermal diffusivity of olivine (Gibert et al., 2003, 2005). Thermo-mechanical erosion of the lithosphere by small-scale convection atop a mantle plume, subduction zones, or at the edges of a cratonic root may accelerate this evolution locally, producing transient high thermal gradients (up to $20^{\circ} \mathrm{C} / \mathrm{km}$ ) in the deep lithospheric mantle (e.g., Agrusta et al., 2013; Arcay et al., 2005; Morency et al., 2002). Evidence for these disequilibrium temperature gradients is rare, but $100-200{ }^{\circ} \mathrm{C}$ heating of the lithospheric mantle above a mantle plume was, for instance, suggested based on garnet destabilization microstructures in xenoliths from the Labait volcano in Tanzania (Lee and Rudnick, 1999). Localized shearing in the lithospheric mantle may also produce high transient thermal gradients at the $\mathrm{km}$ scale. For instance, in the Beni Bousera massif (N Morocco), functioning of a lithospheric-scale transtensional shear zone resulted in a thermal gradient of $>100^{\circ} \mathrm{C} / \mathrm{km}$ across the shear zone (Frets et al., 2014).

Beneath continental rifts or volcanic arcs, heat advection by percolating melts may also induce transient heating of the lithospheric mantle. If melt percolation leads to refertilisation (pyroxenes or plagioclase crystallization), as observed in the Lherz peridotite massif (Le Roux et al., 2007), latent heating may further contribute to local temperature increase in the mantle. The size of these melt-related thermal anomalies depends on the type and scale of the reactive melt percolation process. Microstructural and petrologic evidence for transient heating associated with localized melt percolation and shearing in the lithospheric mantle is observed, for instance, in mantle xenoliths from active sections of the East African rift (Baptiste et al., 2015) and from the vicinity of the $4^{\circ} 50^{\prime}$ shear zone in Hoggar (Kourim et al., 2015). Finally, metasomatism leading to crystallization of minerals enriched in radiogenic elements, such as apatite or phlogopite, may enhance the heat production in the lithospheric mantle by 0.05 to $0.25 \mu \mathrm{W} \cdot \mathrm{m}^{-3}$ and trigger the development of a local thermal heterogeneity (Neves et al., 2008). The length scale of the resulting thermal anomalies is controlled by the extent of the metasomatic process, which might affect large volumes atop subduction zones, in particular above flat slabs (Downes et al., 2004; Lee, 2005). Pervasive enrichment in phlogopite is observed, for instance, in the Finero peridotite massif in the Alps (Zanetti et al., 1999). Metasomatism associated with percolation of small fractions of enriched melts may also be a common phenomenon in the shallow levels of the lithospheric mantle due to progressive enrichment of the melts during reactive transport through the lithospheric mantle (Bedini et al., 1997). Phlogopite and apatite are widespread accessory mineral in peridotite xenoliths (cf. review by O'Reilly and Griffin, 2000), but they are often associated with vein-like structures. Pervasive enrichment is rare. However, it is observed in xenoliths from the Middle Atlas in Morocco (Raffone et al., 2009) or from the Kaapvaal craton (e.g., Dawson and Smith, 1977). These metasomatically produced thermal heterogeneities may persist over time scales corresponding to the radiogenic decay of ${ }^{40} \mathrm{~K}$ and ${ }^{235} \mathrm{U}$, which have half-lives on the order of 1.25 G.y. and 700 m.y., respectively.

In summary, many processes may produce 'hot' domains in the lithospheric mantle. These domains will display lower strength than their surroundings. The time scales of existence of these soft heterogeneities depend on their size, their origin, and on the local thermal gradient. Small thermal heterogeneities survive for very short times, but large ones may be preserved up to several tens of m.y. For instance, characteristic times for re-equilibrating the thermal gradient in an aborted rift are ca. 50 m.y. Moreover, if the crust has been thinned during the extensional episode, static thermal reequilibration will lead to an inversion of the rheological contrast: the soft heterogeneity will become stiff due to cooler temperatures at the Moho, which will remain shallower than in the surroundings (Tommasi and Vauchez, 1997). On the opposite, if the crust has been thickened and heated (as in "hot orogens" for instance), the middle crust may buffer thermal conduction and therefore maintain an abnormally hot geotherm over tens of m.y. (e.g., Kukkonen and Lauri, 2009; Whittington et al., 2009).

In contrast, the processes controlling the characteristic time scales of preservation of cold and stiff domains within a plate remain poorly understood. The difference in geothermal gradient between Archean cratons and Proterozoic terranes can only be explained by a primordial and long-lived variation in the lithosphere thickness (Nyblade and Pollack, 1993). The coherence between Archean ages in the crust and Re-Os data in peridotite xenoliths in the Kaapvaal, Siberia, Wyoming and Tanzania cratons corroborates this assumption (Pearson, 1999). Such time scales are, however, at odds with geodynamical modeling results, which show that neither the density contrast due to the more refractory nature of the cratonic peridotites, nor the increase in viscosity due to the lower geotherm suffice to preserve a cratonic mantle root from recycling in the convective mantle on G.y. time scales (Doin et al., 1997). To avoid recycling since the Archean, cratonic roots must have significantly higher strength than the convective mantle and, preferably, be surrounded by weak continental lithosphere (Lenardic et al., 2003). On the other hand, there is evidence, as in the eastern part of the North China, for relatively fast (5-100 m.y.) destruction in Jurassic-Cretaceous times of an Archean cratonic mantle root (Griffin et al., 1998; Menzies and Xu, 1998). These short time spans also are inconsistent with numerical models, in which several hundreds of m.y. are necessary to fully recycle a thick mantle root in the convective mantle (e.g., Doin et al., 1997; King, 2005; Lenardic et al., 2003).

\subsection{Chemical and mineralogical heterogeneity}

Orogenic massifs and xenoliths from off-craton continental lithospheric mantle have dominantly lherzolitic compositions (cf. reviews 
by Pearson et al., 2003; Bodinier and Godard, 2007). Refractory harzburgitic compositions ( $<5 \%$ clinopyroxene) predominate solely among cratonic xenoliths equilibrated at low-temperature $\left(<1000^{\circ} \mathrm{C}\right)$ and in ophiolites, which sample the first kilometers of the oceanic lithosphere. Partial melting is a major process in the differentiation of the lithospheric mantle. It plays an essential role in creating large-scale refractory (Fe-poor, olivine-rich) domains. A variety of geodynamic scenarios, ranging from major plume impacts to subduction, were proposed for the formation of cratonic roots, but all converge on the fact that extensive partial melting is needed to explain the highly refractory compositions of cratonic xenoliths (cf. review in Aulbach, 2012). High melting degrees at ridges also explain the predominance of harzburgites in ophiolites (Boudier and Nicolas, 1985). On the other hand, the preponderantly fertile compositions of the Phanerozoic subcontinental lithospheric mantle and of the deep cratonic and oceanic lithospheres suggest that either they consist of convective mantle accreted to the lithosphere by cooling or they were refertilized by interaction with asthenospheric melts.

In contrast, within a melting domain, i.e., at shorter length scales $(\leq \mathrm{km})$, partial melting homogenizes compositions, since more fertile domains start melting earlier. During lithospheric thinning, partial melting may thus create a compositional contrast between the asthenosphere, homogenized by melting, and the lithosphere, which may retain a strong compositional heterogeneity, as observed across the recrystallization front in the Ronda peridotite massif (Lenoir et al., 2001). At these scales, reactive percolation of melts and fluids through the lithosphere (metasomatism) is the most effective process to produce compositional heterogeneity in the lithospheric mantle. Metasomatism is ubiquitous in mantle xenoliths (cf. reviews by Pearson et al., 2003 and O'Reilly and Griffin, 2013). Its effects range from enrichment in light rare earth elements contents, crystallization of accessory phases (hydrous minerals, apatite...), to significant variations in the mineralogical composition of the peridotite, due to crystallization of hydrous phases (amphiboles, phlogopite) or changes in the relative contents of olivine and pyroxenes in response to refertilisation or dunitization reactions (e.g., Bedini et al., 1997; Bodinier et al., 1990; O'Reilly and Griffin, 2013).

Development of compositional heterogeneity by reactive melt percolation or partial crystallization of melts is well illustrated in peridotite massifs and ophiolites, which are usually composed of harzburgites and/or lherzolites crosscut by dunite bodies and pyroxenite veins. These compositional variations record reactive percolation of melts; the products of this process are function of the melt (and of the peridotite) composition and of the pressure and temperature conditions. For instance, the Lherz and Ronda peridotite massifs display a $1 \mathrm{~km}$ thick domain composed by a metric to decametric interleaving of harzburgites and lherzolites with irregular, but elongated shapes (Fig. 4). This interleaving records refertilisation of the lithospheric mantle by reactive percolation of basaltic melts under high temperature and moderate pressure conditions, which led to formation of lherzolites at the expenses of harzburgites (Le Roux et al., 2007; Soustelle et al., 2009). Local accumulation of melts during this process produced cm-scale pyroxenitic layers with diffuse limits parallel to the harzburgite-lherzolite contacts (Fig. 4b and d). Indeed, melt-rock reaction and partial crystallization of melts may explain most of the $\mathrm{cm}$ to tens of $\mathrm{cm}$ wide pyroxenite layers (Figs. 4d-f and 6), which are ubiquitous in peridotite massifs (e.g., Bodinier et al., 1987; Garrido and Bodinier, 1999) and xenoliths (e.g., Sen, 1988). At low pressures, refertilisation is characterized by crystallization of secondary plagioclase, as recorded for instance in Lanzo (Bodinier, 1988; Boudier, 1978; Kaczmarek and Müntener, 2008; Piccardo et al., 2007), Othrys (Dijkstra et al., 2001), or in the crust-mantle transition zone in ophiolites (Boudier and Nicolas, 1995).

In addition, interaction of Si-undersaturated basalts with peridotites results in crystallization of olivine at the expenses of pyroxenes, forming dunites (Berger and Vannier, 1984; Kelemen et al., 1990; Morgan and Liang, 2003; Quick, 1982). Dunites are ubiquitous in shallow sections of ophiolites (e.g., Dijkstra et al., 2003; Kelemen and Dick, 1995;
Nicolas, 1986; Quick, 1982; Suhr et al., 2003; Tommasi et al., 2006). They are also common in orogenic massifs, though volumetrically less important (e.g., Boudier, 1978; Niida, 1984; Shervais, 1978). They occur most commonly as $\mathrm{cm}$ to tens of $\mathrm{cm}$ wide bands, but bodies up to tens of meters wide (Fig. 5) were described in the crust-mantle transition zone in ophiolites (e.g., Boudier and Nicolas, 1995; Braun and Kelemen, 2002; Dijkstra et al., 2003; Suhr et al., 2003). Two models have been proposed to explain their usual planar structure: melt-rock reaction at the walls of dikes (Nicolas, 1986) or channeled melt flow due to a reaction-induced permeability increase (Kelemen et al., 1995).

Yet, compositional layering results most often from deformation coeval or following reactive melt percolation. Deformation may stretch, fold and transpose preexisting pyroxenite bands, giving rise to a centimetric to metric scale compositional banding concordant to the peridotites foliation, as the one that characterizes the upper sections of the Lherz (Fig. 4e), Beni Bousera (Fig. 6), and Ronda peridotites (Frets et al., 2012; Kornprobst, 1969; Obata, 1980) and the Horoman massif (Niida, 1984; Obata and Nagahara, 1987; Toramaru et al., 2001). The most effective process producing pervasive small-scale compositional layering is nevertheless shear-controlled melt segregation during deformation in the presence of melt (Holtzman et al., 2003). This process has been proposed to explain the $\mathrm{cm}$-scale compositional layering marked by plagioclase and pyroxene enrichment in the crust-mantle transition zone of the Oman ophiolite and in the Lanzo massif (Higgie and Tommasi, 2012, 2014; Jousselin et al., 2012) and the cm-scale diffuse lherzolitewebsterite layering (Fig. 4e) in the lower section of the Lherz massif (Le Roux et al., 2008). Postkinematic (static) melt migration may also produce small-scale ( $\mathrm{mm}$ to $\mathrm{cm}$ ) compositional layering if the preexisting peridotite fabric (shape and crystal preferred orientation) controls melt transport. This phenomenon has, for instance, been invoked to explain the $\mathrm{cm}$-scale websteritic lenses parallel to the harzburgites' foliation in the Lherz peridotite massif (Fig. 4c; Le Roux et al., 2008).

Metasomatism may also produce crystallization of hydrous minerals (amphiboles and phlogopite), but usually in low proportions $(<10 \%)$. Local enrichment in hydrous minerals is nevertheless observed within veins or in low-temperature mylonitic zones, which may have widths ranging from a few meters to hundreds of meters (cf. reviews by Drury et al., 1991; Vauchez et al., 2012). Pervasive enrichment in hydrous minerals at the hundreds of meters or larger scales is limited to rare subduction-related peridotite massifs, such as the Finero phlogopite and amphibole-bearing peridotite massif in the Alps (Zanetti et al., 1999), the Hayachine-Miyamori amphibole-peridotites in northeast Japan (Ozawa, 1988), and the chlorite-bearing garnet-peridotites from the Western Gneiss zone in Norway and the Alps, like Alpe Arami and Ulten (Buiskol Toxopeus, 1977; Medaris, 1980; Rampone and Morten, 2001). These observations suggest that, except atop subduction zones where pervasive hydration of the peridotites at the km scale is observed, peridotites with high proportion of hydrous phases only occur in the vicinity of veins at centimetric to metric scales.

Last but not least, partial melting and metasomatism control the water content in the nominally anhydrous mantle minerals (olivine and pyroxenes). Due to the high incompatibility of hydrogen, partial melting causes dehydration of olivine. Metasomatism may produce either hydration or dehydration, depending on the water fugacity in the melt, the composition of the peridotite, and the pressure and temperature at which the interaction takes place (Demouchy et al., 2015). By consequence, water contents in olivine determined by infrared spectroscopy data on mantle xenoliths show an extreme variability even at a single locality (from dry to almost saturated) and do not correlate with the partial melting degree recorded by the peridotite (cf. data compilations in Baptiste et al., 2012; Peslier et al., 2012; Demouchy et al., 2015).

\subsection{Structural heterogeneity}

Structural heterogeneity in the lithospheric mantle is produced by contrasts in grain size or crystal preferred orientations. It arises 

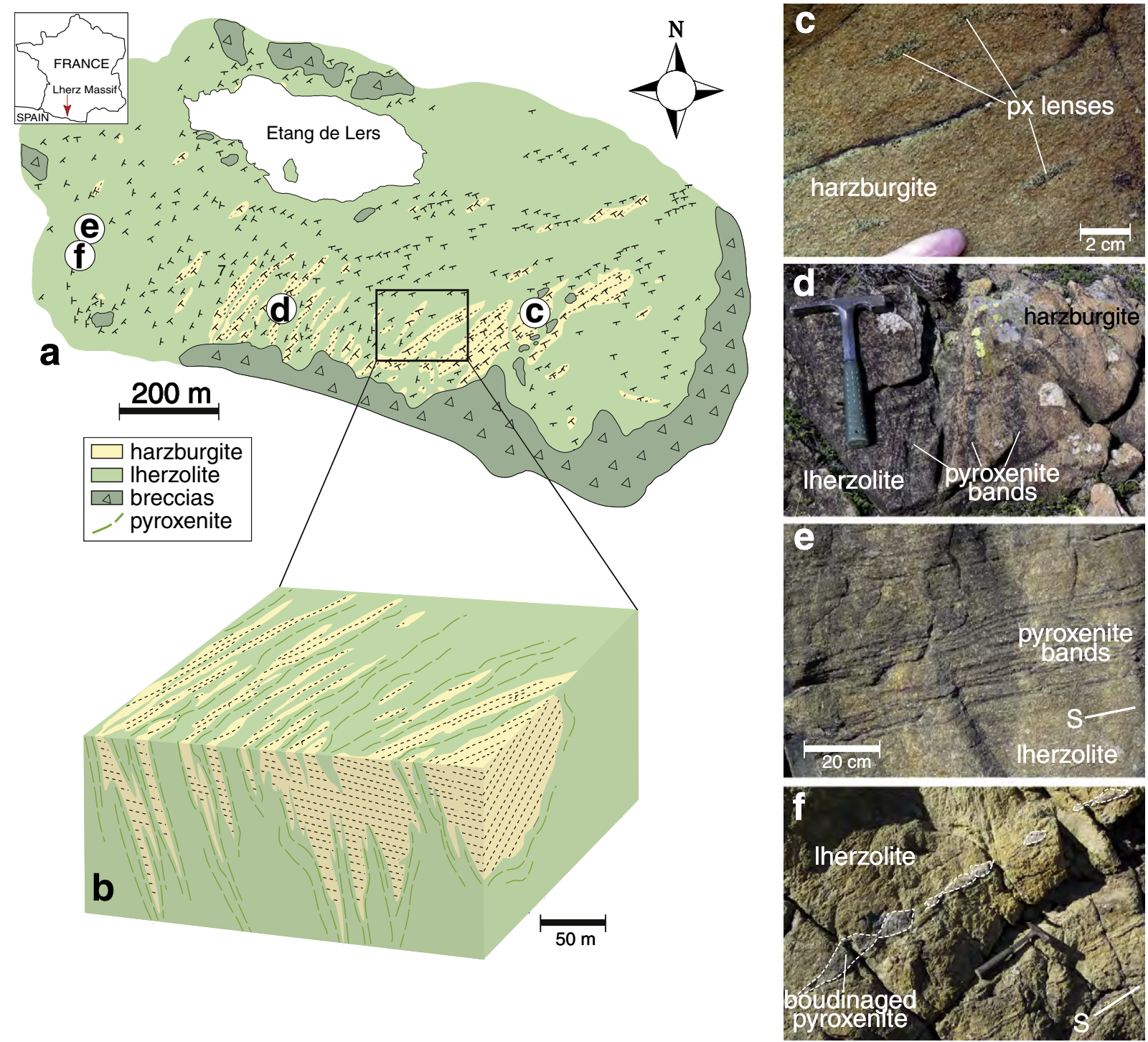

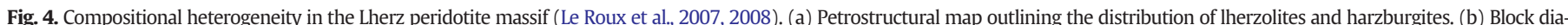

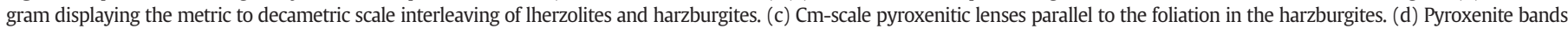
paralleling a harzburgite-lherzolite contact. (e) Penetrative pyroxenite layering in the lherzolites distal to the harzburgite bodies. (f) Boudinaged pyroxenite layers in the distal lherzolites.

essentially from deformation, though grain size reduction may also be produced by reactions. In this section, we focus on the microstructural (grain size) evolution. Development of crystal preferred orientations is discussed in the next section, because it is a key parameter controlling anisotropy.

During deformation, grain size changes in response to dynamic recrystallization. Nucleation of new grains, by subgrain rotation or bulging, produces grain size reduction, which is counteracted by grain growth through grain boundary migration. The equilibrium grain size is controlled by the rate of mechanical work and by the grain growth rate, which depends to the first order on temperature (Austin and Evans, 2007; Rozel et al., 2011). Effective grain size reduction down to tens of $\mu \mathrm{m}$ is therefore limited to zones deforming under high stress conditions due to high strain rate and/or low temperature. Indeed, fine-grained peridotites represent minor volumes of the peridotites exposed at the Earth surface (cf. review in Vauchez et al., 2012). Peridotite massifs and xenoliths show dominantly coarse-grained porphyroclastic or granular microstructures.

Descriptions of mylonite (partial recrystallization with an average recrystallized grain size $<200 \mu \mathrm{m}$ ) and ultramylonite (almost total recrystallization with an average recrystallized grain size $<20 \mu \mathrm{m}$ ) occurrences in peridotite massifs and ophiolites corroborates that these rocks form essentially during shearing under low-temperature (<1000 C; Boudier, 1978; Obata, 1980; Boudier and Coleman, 1981; Nicolas et al., 1987; Drury et al., 1991; Strating et al., 1993; Vissers et al., 1995; Van der Wal and Vissers, 1996; Vissers et al., 1997; Newman et al., 1999; Dijkstra et al., 2004; Michibayashi and Mainprice, 2004; Toy et al., 2010; Kaczmarek and Tommasi, 2011; Michibayashi and Oohara, 2013; Frets et al., 2014). These studies describe three main types of occurrence of mylonitic and ultramylonitic peridotites. First, kilometric-scale shear zones characterized by a continuous decrease in grain size (Figs. 6 and 7). In these shear zones, mylonites outcrop in 100-200 m wide domains at the center or at one of borders of the shear zone (Figs. 6 and 7). Ultramylonites, when present, form cm-scale bands parallel or at low angle to the mylonitic foliation (Figs. 7 and 8). Mylonitic and ultramylonitic peridotites also occur in km-scale networks of anastomozed shear zones 1-10 m wide and in isolated decametric- to centimetric-scale shear zones. These structures are characterized by sharp grain size variations (at the $\mathrm{cm}$ scale). They often show mylonitic lenses surrounded by $\mathrm{mm}$ to $\mathrm{cm}$-scale ultramylonite bands. 


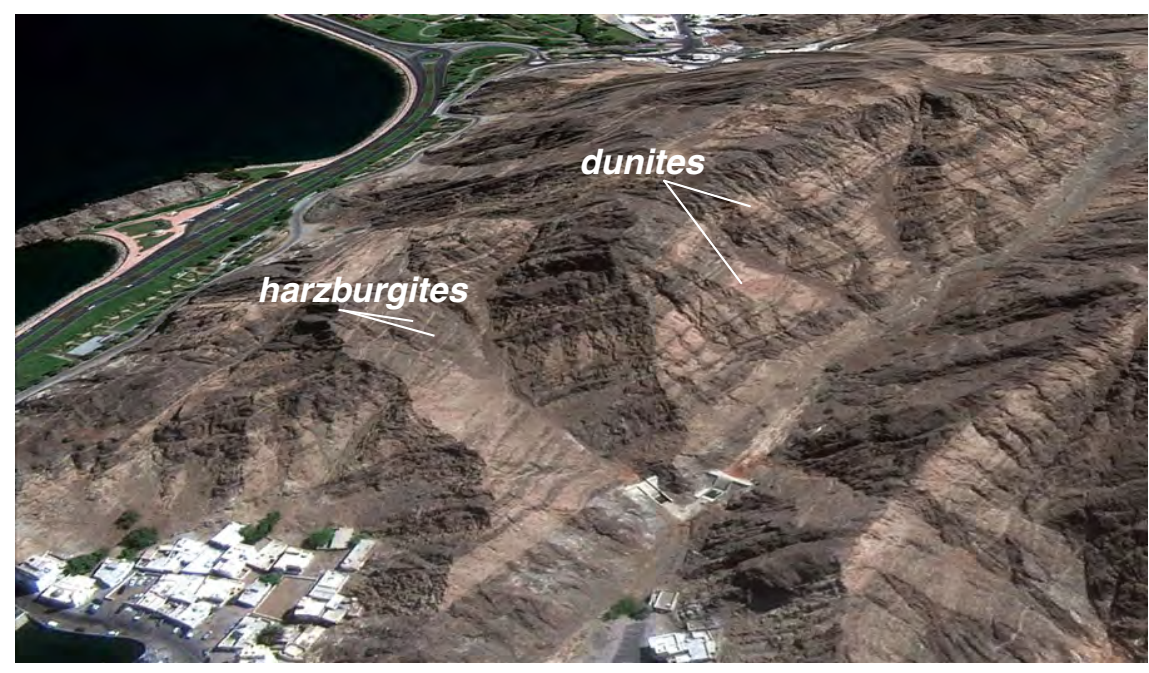

Fig. 5. Decametric scale dunite bodies in the crust-mantle transition zone of the Oman ophiolite. Google Earth - DigitalGlobe 2015 image.

Development of mylonitic zones in orogenic peridotites is usually associated with exhumation of the subcontinental lithospheric mantle in extensional or transtensional environments, as in Ronda and Beni Bousera (Frets et al., 2014; Garrido et al., 2011; Soustelle et al., 2009), Turon de Tecouere (Newman et al., 1999; Vissers et al., 1997), Lanzo (Boudier, 1978; Kaczmarek and Tommasi, 2011), Erro-Tobio (Strating et al., 1993), or Zabargad (Nicolas et al., 1987). In ophiolites, mylonitic and ultramylonitic zones are related to transform faults or to the obduction process (Boudier and Coleman, 1981; Boudier et al., 1988; Dijkstra et al., 2002; Michibayashi and Mainprice, 2004; Prinzhofer and Nicolas, 1980; Suhr, 1993; Titus et al., 2011). In most cases, deformation occurred under retrogressive conditions, in which grain size reduction is associated with progressive strain localization. The garnet and spinel mylonites from Beni Bousera are an exception. There, shearing resulted in development of a high temperature gradient $\left(>100{ }^{\circ} \mathrm{C} / \mathrm{km}\right)$ across the shear zone (Fig. 6); strain localization in the hot domain of the shear zone allowed for the preservation in the hanging wall of the mylonitic structures formed during the initial stages of the shear zone activity at mid-lithospheric depths (Frets et al., 2014).

Mylonitic microstructures and $\mathrm{mm}$ - to cm-scale ultramylonitic bands are also present in abyssal peridotites dredged along fracture zones and the Mariana trench (ca. 14\% of the total sampled material, Jaroslow et al., 1996; Warren and Hirth, 2006). These rocks record low-temperature, high stress deformation, often under hydrated conditions, in the shallow sub-oceanic lithospheric mantle beneath transform faults and at trenches. Though rare, peridotite mylonites and ultramylonites also occur in minor quantities in peridotite xenoliths suites that sample the lithospheric mantle in: (i) active extensional or transtensional plate boundaries, like the East African rift (Baptiste et al., 2015; Kaeser et al., 2006), the Baja California (Basu, 1977; Cabanes and Mercier, 1988), and Montferrier, S France (Cabanes and Briqueu, 1987), (ii) convergent plate boundaries, such as the Persani mountains (Falus et al., 2008) and Oran in Algeria (Zerka et al., 2002), or (iii) intraplate settings were deformation is associated with reactivation of preexisting lithospheric-scale faults as the Tanlu fault in NE China (Xu et al., 1993), the North Middle Atlas Fault in eastern Morocco (El Messbahi et al., 2015), or the Panafrican $4^{\circ} 50^{\prime}$ shear zone in the Hoggar massif in Algeria (Kourim et al., 2015).

Rather surprisingly, actual mylonites are not observed among the xenoliths extracted from the vicinity of the active San Andreas transform plate boundary (Titus et al., 2007). Xenoliths from the neighboring Mojave region show, however, a variety of microstructures, including porphyroclastic peridotites and coarse-grained mylonites with recrystallized grain sizes ranging from 300 to $600 \mu \mathrm{m}$ (Behr and Hirth, 2014). This corroborates that, though high strains produce recrystallization, high synkinematic temperatures and low stresses limit grain size reduction. Effective grain size reduction during high-temperature deformation is restricted to kimberlite-borne mylonitic peridotites from cratons (Baptiste et al., 2012; Bascou et al., 2011; Boullier and Gueguen, 1975; Boullier and Nicolas, 1973; Goetze, 1975; Kopylova et al., 1999; Skemer and Karato, 2008) and to alnoïte-borne xenoliths from the base of the Ontong Java lithospheric mantle (Tommasi and Ishikawa, 2014). However, the formation and preservation of mylonitic microstructures at the high equilibrium temperatures recorded by these xenoliths $\left(>1300{ }^{\circ} \mathrm{C}\right)$ imply extremely high strain rates $\left(>10^{-8} \mathrm{~s}^{-1}\right)$ shortly before their extraction, leading most of the previous authors to interpret these mylonitic microstructures as related to the initial stages of the extraction of volatile-rich melts from the mantle.

A closer analysis of peridotite mylonites and ultramylonites (Figs. 6, 7,8 , and 9) highlights that extreme grain size reduction $(<50 \mu \mathrm{m})$ and phase mixing are always associated with strongly sutured, interpenetrating phase boundaries (in particular between olivine and pyroxenes) and with the crystallization of reactional plagioclase or hydrous minerals (Nicolas et al., 1987; Strating et al., 1993; Furusho and Kanagawa, 1999; Newman et al., 1999; Warren and Hirth, 2006; Toy et al., 2010; Kaczmarek and Tommasi, 2011; Hidas et al., 2013; El Messbahi et al., 2015; Hidas et al., 2015). In mylonites with no evidence for reactions, recrystallized grain sizes are usually $\geq 100 \mu \mathrm{m}$ and phase segregation rather than mixing is the rule (e.g., Behr and Hirth, 2014; Falus et al., 2008). For instance, in kimberlite-borne peridotite mylonites, stretching of recrystallized aggregates formed at the expenses of olivine and orthopyroxene porphyroclasts results in a mmscale compositional layering (Fig. 9). These observations are consistent with experimental data on fine-grained olivine-pyroxene aggregates, which show mineral aggregation in response to deformation by grain boundary sliding (Hiraga et al., 2013). Numerical models of deformation of rocks composed by minerals with different strength also show mechanical segregation leading to development of a compositional layering parallel to the shear plane (Dabrowski et al., 2012). Even in deformation experiments in which $\mathrm{mm}$-scale orthopyroxene clasts are embedded in a fine-grained $(<10 \mu \mathrm{m})$ olivine matrix, mixing is limited to the first-neighbors-layer around a few orthopyroxene clasts (Linckens et al., 2014). Altogether these data suggest that synkinematic low-temperature reactions, triggered by decompression or interactions with fluids, are essential to reduce the grain size down to a few microns 

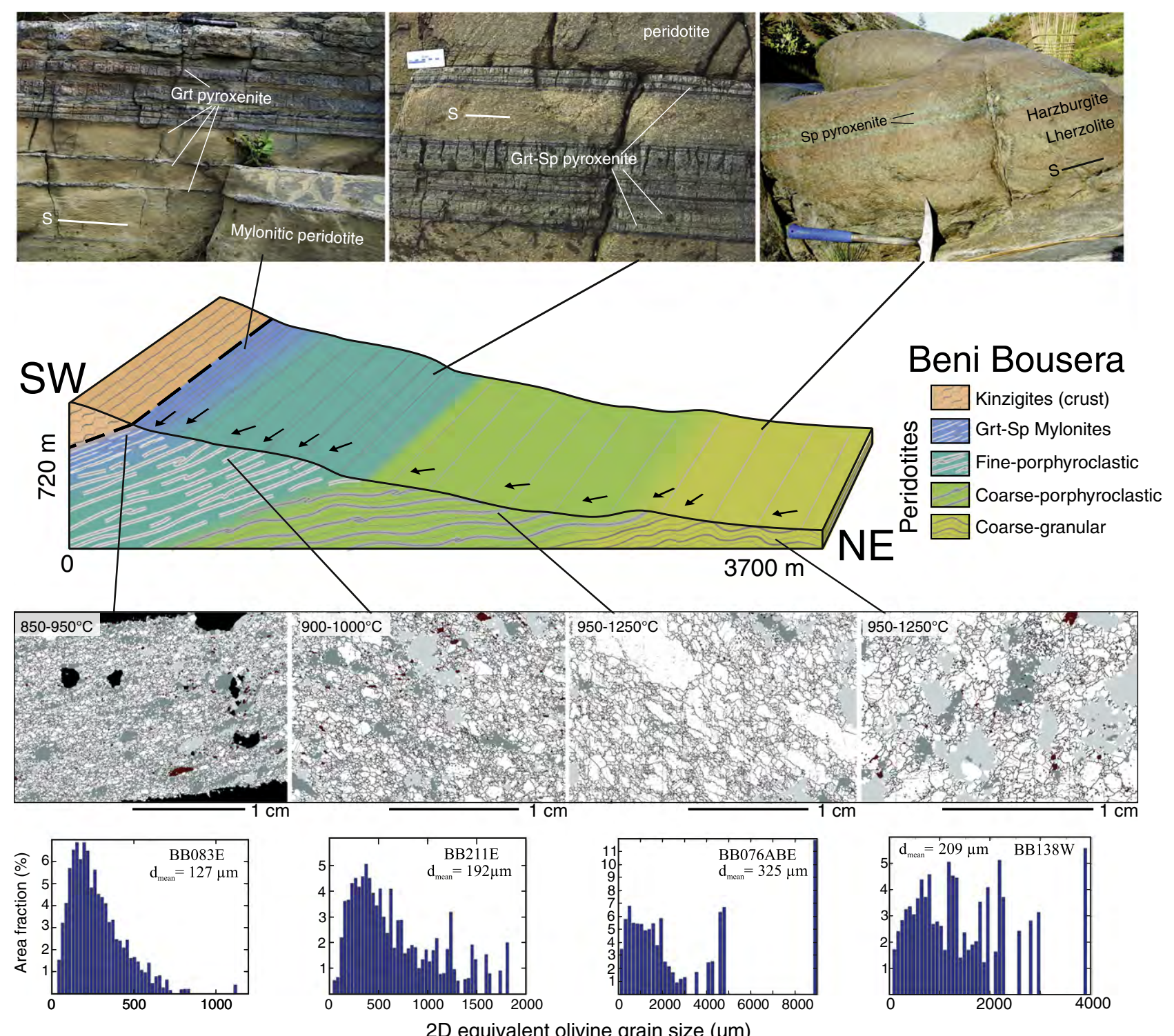

$2 \mathrm{D}$ equivalent olivine grain size $(\mu \mathrm{m})$

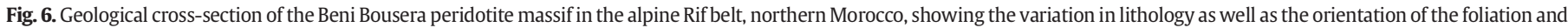

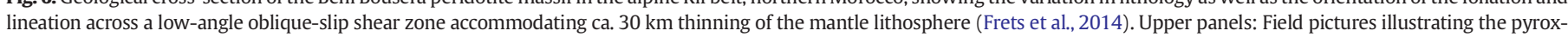

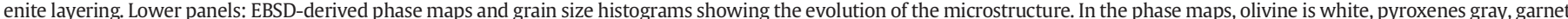

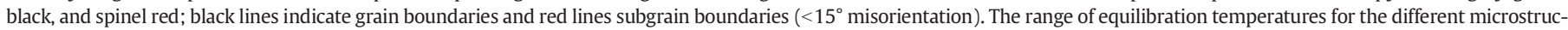
tures is indicated at the top left of each map.

and to produce phase mixing in the mantle. The feedbacks between reactions, grain size reduction and strain localization result nevertheless in these processes being focused in small volumes, typically a network of multiple ultramylonite bands, usually a few mm wide, which occur in $<100 \mathrm{~m}$ wide low-temperature domains of the shear zones.

These observations provide strong constraints on the preservation of grain size heterogeneities in the lithospheric mantle. The main process erasing grain size heterogeneities is grain growth, which is both time and temperature dependent. In the cold shallow levels of the lithospheric mantle, it is sluggish. For instance, at a temperature of $800{ }^{\circ} \mathrm{C}$, under dry conditions, growth of an olivine grain from a few $\mu \mathrm{m}$ to $1 \mathrm{~mm}$ sizes requires $\gg 1$ G.y. (Evans et al., 2001). At higher temperatures, olivine grain growth is fast (Karato, 1989; Toriumi, 1982), unless slowed down by second-phase pinning. Experiments on well-mixed, fine-grained olivine-enstatite or olivine-diopside mixtures show that large pyroxene contents may reduce olivine grain growth rates by up to a factor 4 (Hiraga et al., 2010; Ohuchi and Nakamura, 2007).
However, in nature, pyroxenes usually have plurimillimetric sizes and are not homogeneously dispersed in the aggregate, limiting the effect of pinning. Even in strongly recrystallized mylonites, as the one presented in Fig. 9, the characteristic pinning length will be controlled by the spacing of the orthopyroxene aggregates, that is $>100 \mu \mathrm{m}$ normal to the foliation and several millimeters parallel to it. Effective pinning is therefore restricted to peridotite mylonites or ultramylonites where synkinematic reactions produced grain size reduction and phase mixing. However, the latter represent, as discussed above, small volumes of the lithospheric mantle. Thus, given geological time scales, grain growth is an effective process. This prediction is corroborated by the predominance of coarse grain sizes ( $\geq 1 \mathrm{~mm}$ in average) in peridotite massifs and xenoliths. Annealed textures and very coarse grain sizes (with olivine attaining $>1 \mathrm{~cm}$ in diameter) are particularly common among garnet peridotites from cratonic environments, which have been stable over very long time spans (Boyd and Gurney, 1986; Boyd et al., 1997; Kopylova et al., 1999; Pearson et al., 2003; Vauchez et al., 2005; Baptiste et al., 2012). 


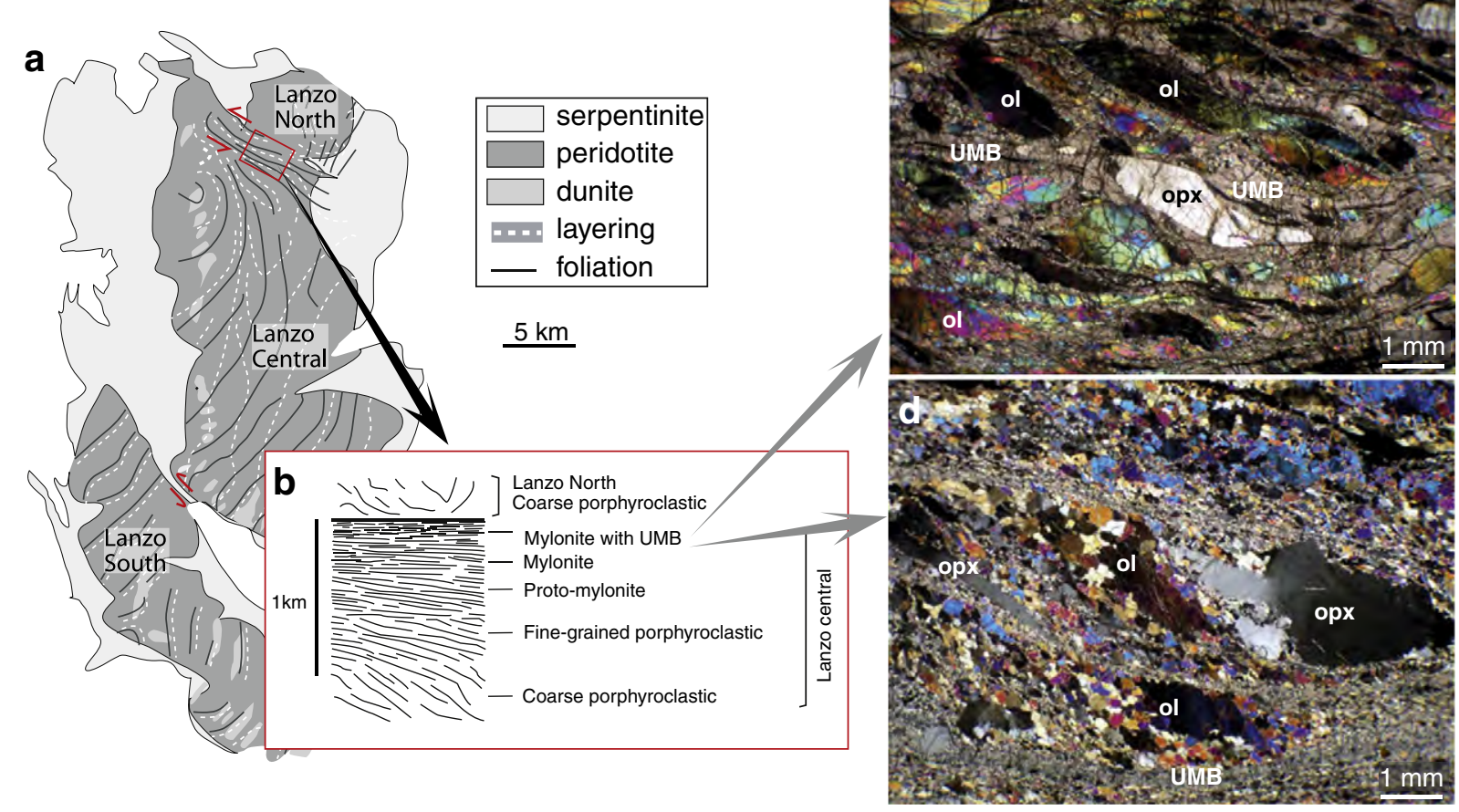

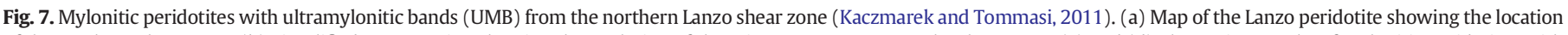

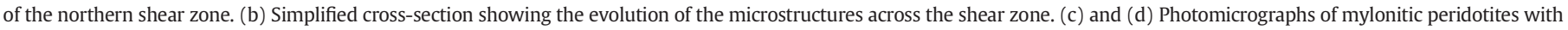
ultramylonitic bands (UMB); cross-polarized light; ol: olivine, opx: orthopyroxene.

\subsection{Anisotropy}

The main source of anisotropy of physical properties in the lithospheric mantle is the preferred orientation of olivine crystals, because olivine, which is the volumetrically dominant phase ( $>60 \%$ ), is highly anisotropic for most physical properties. Olivine shows a strong elastic anisotropy (Abramson et al., 1997; Kumazawa and Anderson, 1969) and coherent preferred orientation of elastically anisotropic olivine
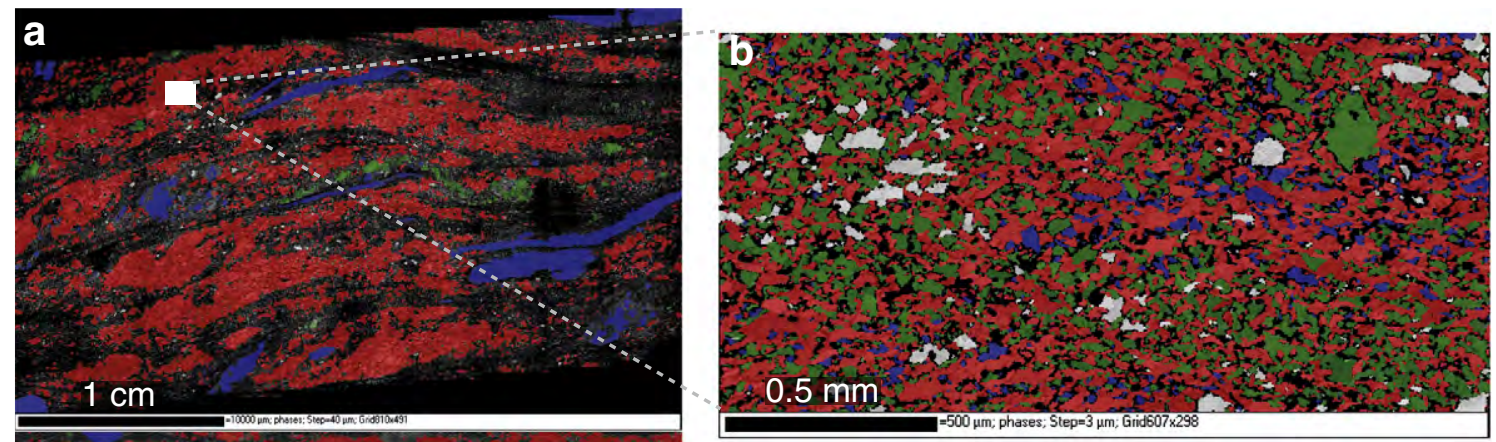

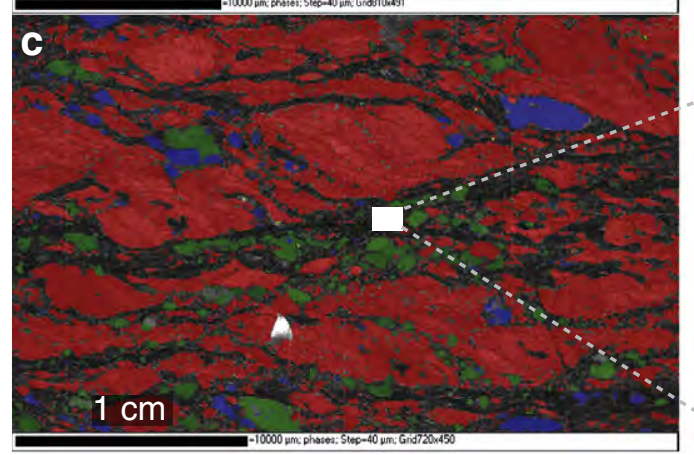

Olivine

Orthopyroxene

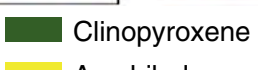

Clinopyroxene

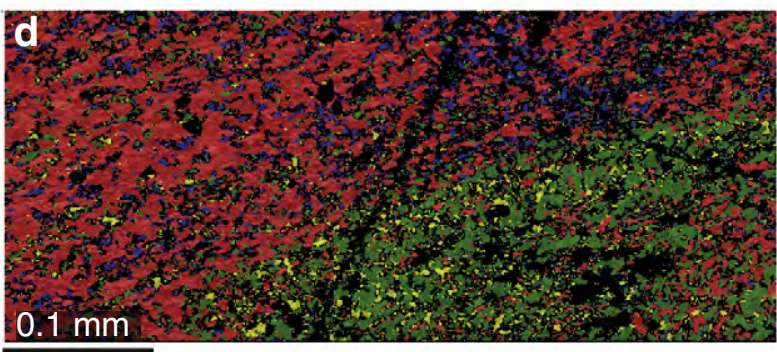

Plagioclase

Non-indexed area

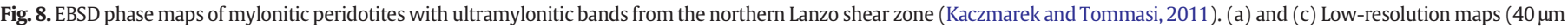

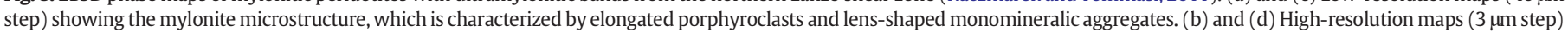
of the ultramylonitic bands showing phase mixing, enrichment in secondary plagioclase, clinopyroxene, and amphibole, and sutured interphase grain boundaries. 


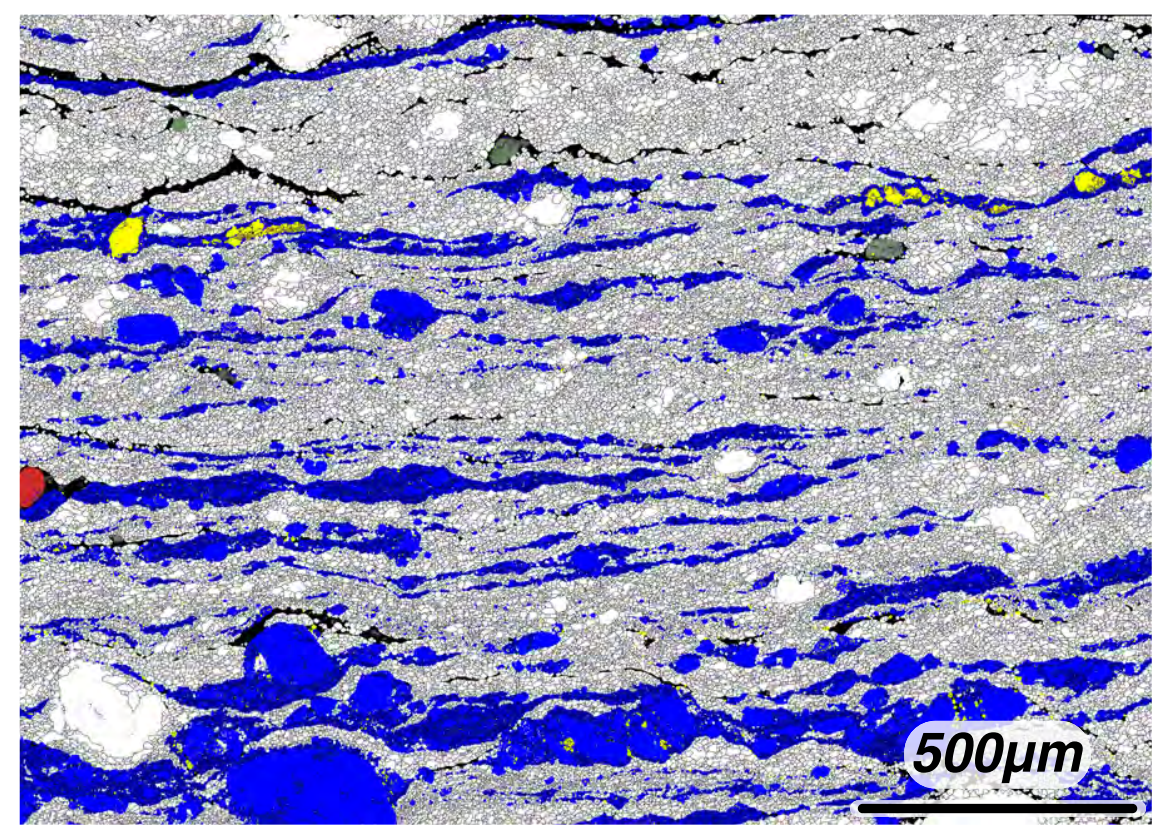

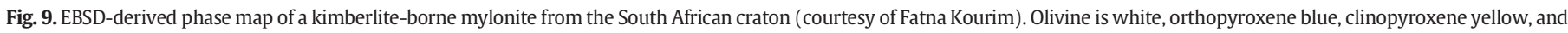

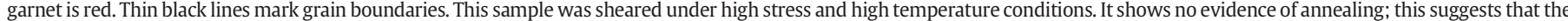

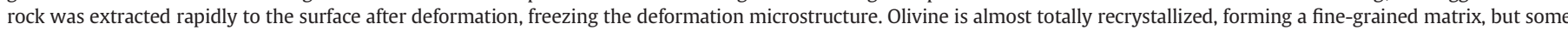

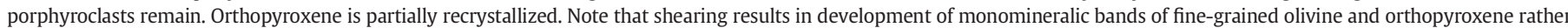

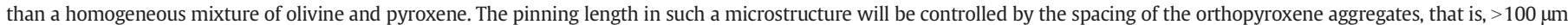
normal to the foliation and several millimeters parallel to it.

crystals at the tens of km scales may account for most of the seismic anisotropy detected in the upper mantle (Mainprice, 2007). The viscoplastic behavior, that is, the ductile deformation by dislocation creep, and the heat conduction in olivine crystals are also extremely anisotropic (Kobayashi, 1974; Durham and Goetze, 1977; Bai et al., 1991; Chai et al., 1996; Gibert et al., 2005). Experimental data and numerical models indicate that thermal and viscoplastic anisotropies are also transferred to the rock-scale by the preferred orientation of olivine crystals (Gibert et al., 2003; Hansen et al., 2012; Knoll et al., 2009; Tommasi et al., 2001, 2009).

Another important source of anisotropy is aligned fluid and melt pockets (or layers), but the latter is, as discussed below, both local and transient in the lithospheric mantle. Compositional layering, which is often observed in peridotite massifs (cf. Section 3.2), does not produce significant seismic anisotropy, because the contrast in density and elastic properties between olivine and pyroxenes is weak (Mainprice, 2007).
Enrichment in garnet in the pyroxenites enhances this contrast, but not sufficiently to produce significant anisotropy. In fact, the anisotropy of a layered peridotite-pyroxenite system tends to be reduced relatively to the one displayed by a homogeneous anisotropic peridotite, because garnet-rich pyroxenites usually have very low elastic anisotropy (Fig. 10).

Hydrous minerals, like antigorite, chlorite, phlogopite and amphiboles are strongly anisotropic (Bezacier et al., 2010; Christensen, 2004; Kern et al., 1997; Mainprice and Ildefonse, 2009; Mookherjee and Mainprice, 2014). If they have a preferred orientation, they may influence the lithospheric mantle seismic anisotropy. However, their concentrations are usually too low in the lithospheric mantle for overcoming the olivine-borne signal. Indeed, $>10 \%$ of oriented antigorite is needed for dominating the seismic anisotropy of a serpentinized peridotite (Boudier et al., 2010). In the following, we will therefore focus on the processes producing and destroying crystal preferred orientations (CPOs) and aligned fluid or melt pockets. a

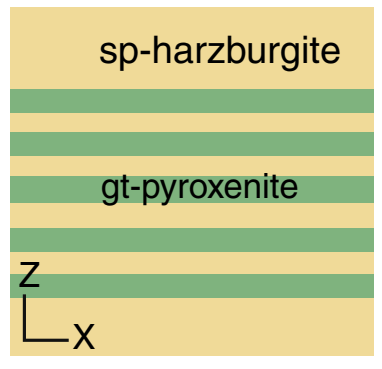

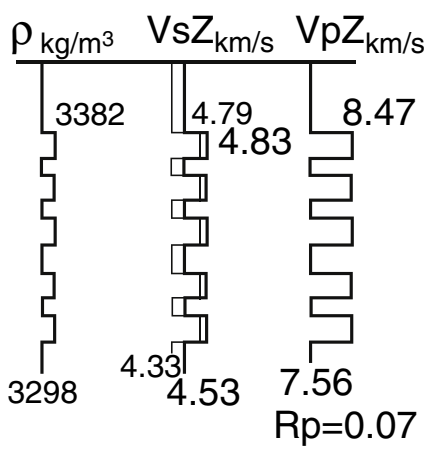

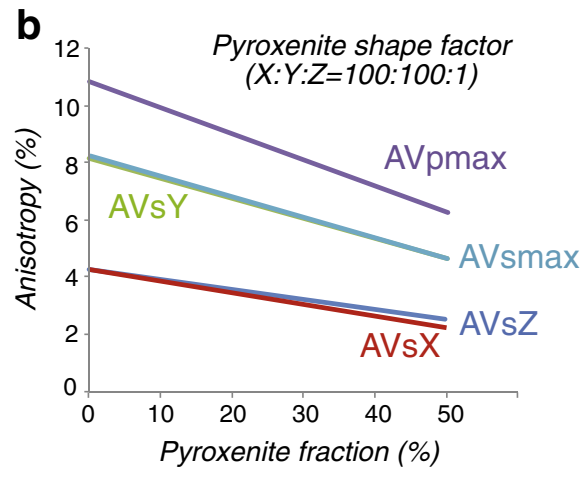

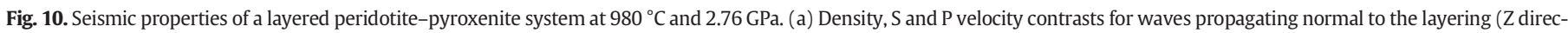

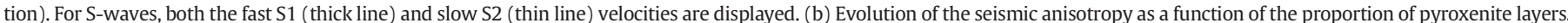

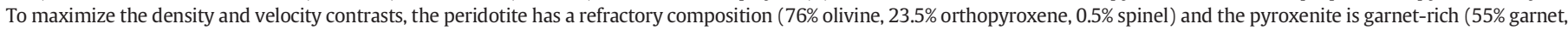

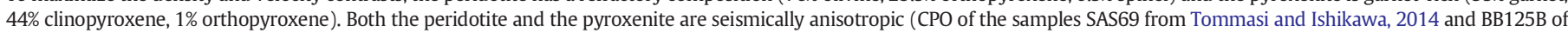
Frets et al., 2012). 
Crystal preferred orientations (CPOs) in mantle rocks are essentially produced and modified by deformation (cf. the historical review by Nicolas and Christensen, 1987). They depend on the deformation kinematics and on how the peridotites deform (active slip systems and interplay between dislocation glide and other strain accommodation mechanisms). The main process creating $\mathrm{CPO}$ is dislocation glide. During dynamic recrystallization, nucleation leads to dispersion of the $\mathrm{CPO}$, while grain growth favors $\mathrm{CPO}$ strengthening by selective growth of crystals with low internal energy (Falus et al., 2011; Guillope and Poirier, 1979; Lee et al., 2002; Nicolas et al., 1973; Poirier and Nicolas, 1975; Tommasi et al., 2000; Toriumi and Karato, 1985). The effect of static recrystallization on CPO is still discussed (e.g., Rollett et al., 2004). Analysis of naturally deformed peridotites displaying variable degrees of annealing or metasomatism suggests that these processes have a limited effect on the olivine CPO (e.g., Tommasi and Ishikawa, 2014; Tommasi et al., 2008; Vauchez and Garrido, 2001). However, extremely annealed peridotites, such as very coarse granular cratonic xenoliths, and peridotites enriched in pyroxenes through reactions with large volumes of fluids or melts often display weak olivine CPO (Baptiste et al., 2012; Kourim et al., 2014; Soustelle and Tommasi, 2010; Soustelle et al., 2013; Zaffarana et al., 2014). Finally, secondary crystallization of olivine during reactive melt percolation under static conditions may lead to dispersion of the olivine CPO (e.g., Tommasi et al., 2004).

The study of naturally deformed peridotites constrains the CPOs and, hence, the associated anisotropy that may exist in the lithospheric mantle. Popularization in the last decade of the electron backscattered diffraction (EBSD) technique for measuring crystals orientation resulted in an exponential increase of measurements of CPO in naturally deformed mantle rocks. In addition, the standardization of automated mapping procedures allows systematic measurement of the orientation of all rock-forming minerals. This allows an improved estimate of the anisotropic physical properties, which correctly accounts for the contribution of all rock-forming minerals. The olivine CPO controls nevertheless the peridotites anisotropy, since it usually represents $\geq 60 \% \mathrm{vol}$. of the rock (Mainprice, 2007).

The last published compilation of olivine CPO data was based on measurements on 110 samples (Ben Ismail and Mainprice, 1998). Analysis of an enlarged dataset (>600 samples), which is part of an ongoing compilation effort, highlights that olivine $\mathrm{CPO}$ of moderate intensity predominate (Fig. 11), but isotropic peridotites are exceptional. The strength of the CPO in a peridotite depends on: (i) the finite strain intensity, (ii) the number of active slip systems, (iii) the relative contribution of dislocation and diffusional processes to deformation, and (iv) the interplay between deformation and the recrystallization processes. The predominance of moderate olivine $\mathrm{CPO}$ in naturally deformed peridotites and the slow evolution of the olivine $\mathrm{CPO}$ in experiments for shear strains $>5$ (Bystricky et al., 2000; Demouchy et al., 2012; Hansen et al., 2014; Zhang and Karato, 1995) suggest that, at high strains, dynamic recrystallization effectively counteracts $\mathrm{CPO}$ strengthening by dislocation glide. This hypothesis is also supported by the correlation between recrystallized grain sizes and CPO strength and by the anticorrelation between recrystallized volumes and CPO strength (Falus et al., 2011). Deformation partitioned among many slip systems and predominance of nucleation over growth during recrystallization may thus account for weak $\mathrm{CPO}$ in low-temperature mylonites (e.g., Boudier and Coleman, 1981; Falus et al., 2011; Frets et al., 2014; Hidas et al., 2015; Kaczmarek and Tommasi, 2011; Newman et al., 1999; Précigout and Hirth, 2014). Additional activation of solid-state or fluid-assisted diffusional processes or grain boundary sliding is, however, required for producing the almost random CPO that characterizes most ultramylonites (e.g., Hidas et al., 2015; Kaczmarek and Tommasi, 2011; Newman et al., 1999; Précigout and Hirth, 2014; Toy et al., 2010; Warren and Hirth, 2006).

The analysis of the enlarged olivine CPO dataset also confirms the predominance of CPO showing marked concentrations of [100] and
[010] ( $85 \%$ of the analyzed samples, Fig. 11). When the peridotite displays a shape-preferred orientation, [100] tends to concentrate parallel to the lineation and [010] normal to the foliation, suggesting dominant activation of the [100](010) slip system. However, the relative concentration and distribution of [100] and [010] vary, leading to CPO with [100]-fiber, orthorhombic, or [010]-fiber symmetries (AG-type, A-type and AB-types of Karato et al., 2008). This variation in the symmetry of the $\mathrm{CPO}$ records changes on the deformation regime or on the relative activity of the different slip systems (Tommasi et al., 1999, 2000). Planar deformations, like simple shear, result in clear orientations of both the dominant slip direction and plane. Constrictional regimes produce strong orientations of the main slip direction (e.g., [100]-fiber symmetry CPO types). Flattening regimes, like transpression, result in dispersion of the dominant slip direction within the foliation plane, producing CPO with a [010]-fiber symmetry. However, [010]-fiber olivine CPO may form in simple shear at low temperature $\left(<1000^{\circ} \mathrm{C}\right)$ through the simultaneous activation of [100] \{0kl\} and [001] \{hk0\} systems due to high stress or high pressure conditions (Demouchy et al., 2013, 2014; Durham and Goetze, 1977; Phakey et al., 1972; Vauchez et al., 2005). Similarly, [100]-fiber symmetry may also form during simple shear at high temperature due to activation of [100] glide on multiple slip planes (Bystricky et al., 2000; Hansen et al., 2014).

The above variations in the $\mathrm{CPO}$ symmetry have nevertheless only a second order effect on the anisotropy of thermo-mechanical properties of upper mantle rocks. Olivine CPO types that significantly change the anisotropy of thermo-mechanical properties in the upper mantle are minor and restricted to specific settings. Olivine CPO characterized by a concentration of [100] parallel to the lineation and of [001] normal to the foliation (E-type of Karato et al., 2008) represent 10\% of the samples (Fig. 11). They are solely observed in harzburgites and dunites deformed in presence of hydrous fluids (Hidas et al., 2015; Mehl et al., 2003; Soustelle and Tommasi, 2010) or melts (Prinzhofer et al., 1980; Tommasi et al., 2006). Olivine CPO marked by [001] maximum parallel to the lineation (D- and C-types of Karato et al., 2008) are still rarer $(\sim 5 \%)$. They are restricted to high- to ultra-high-pressure peridotite massifs (e.g., Frese et al., 2003; Jung et al., 2013; Mizukami et al., 2004; Mockel, 1969; Skemer et al., 2006; Wang et al., 2013b; Xu et al., 2006). This suggests that these CPO probably record subductionrelated deformation rather than a lithospheric evolution.

The systematic observation of olivine CPO in mantle xenoliths and peridotite massifs and the ubiquity of anisotropy in seismic data substantiate that strain-induced CPO is a general feature in the lithospheric mantle. Peridotite massifs show consistent olivine CPO over the $\mathrm{km}$ to tens of $\mathrm{km}$ scale and seismic anisotropy data indicate that this consistency may be maintained at even larger scales. Spatial variations in the strength and orientation of the olivine CPO result from changes in deformation conditions or in kinematics. Except for the water content, parameters controlling olivine CPO development (temperature and pressure) vary gradually within the lithosphere. Thus sharp changes in the orientation of olivine CPO result mostly from superimposed deformations with different kinematics or under different temperature conditions. Moreover, since olivine CPO is usually not destroyed by static processes, CPO-induced anisotropy is preserved over very long time spans in the lithospheric mantle (several G.y. in the cratonic lithosphere), unless it is modified by a new deformation.

Very small melt fractions $(<2 \%)$ may produce much stronger seismic anisotropy than CPO if the melt is contained in very anisometric (elongated or flattened pockets, Blackman and Kendall, 1997; Mainprice, 1997; Vauchez et al., 2000; Kawakatsu et al., 2009; Holtzman and Kendall, 2010). However, this anisotropy is a transient feature, which disappears with melt extraction or crystallization. Melts and fluids are indeed not preserved in the frozen geological record (massifs and xenoliths), but their former presence and distribution may be accessed by the study of the products of their reaction with the peridotite, as discussed in Section 3.2. Formation of planar dunite bodies marks, for instance, focused reactional melt transport in the mantle (e.g., Dijkstra 
a

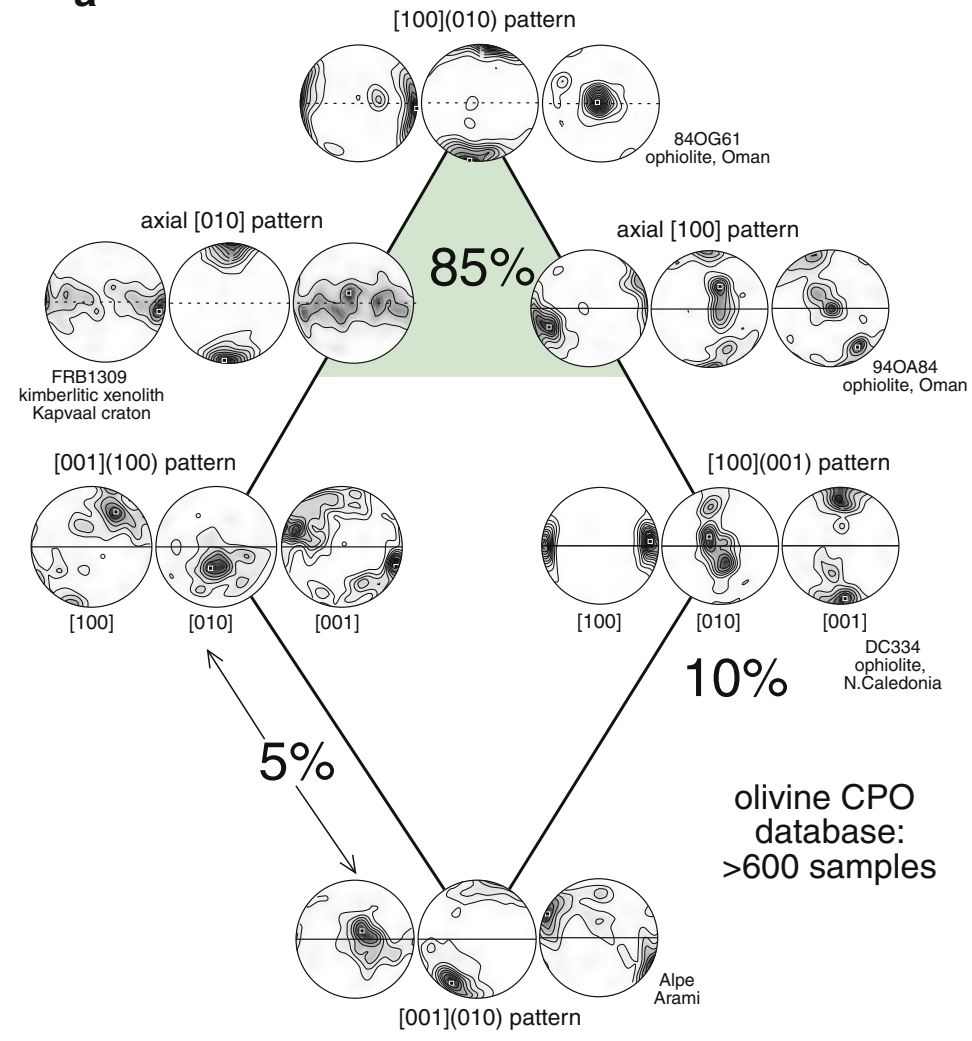

b

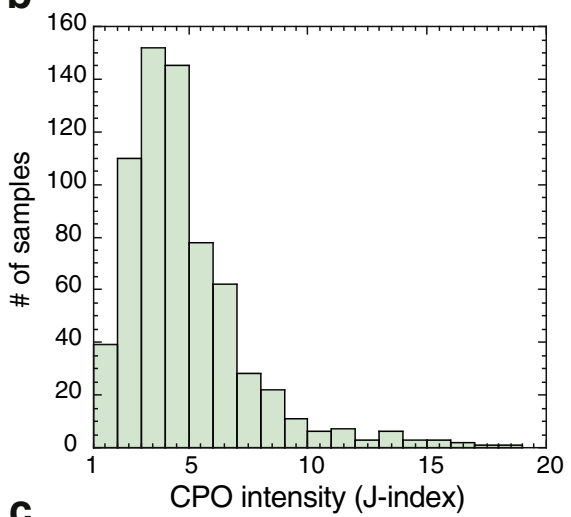

c

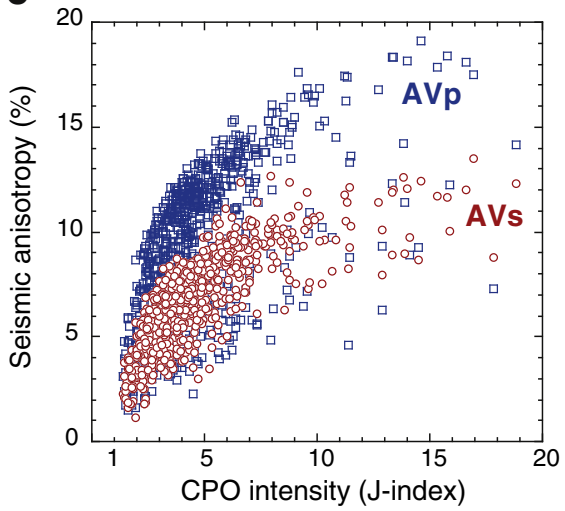

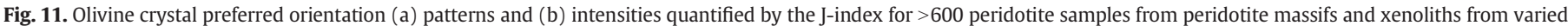

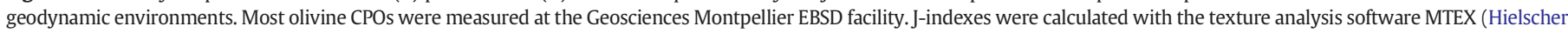

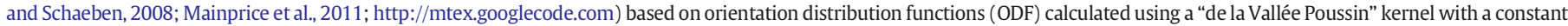
half-width of $10^{\circ}$. (c) Maximum P- and S-wave anisotropies resulting from these olivine CPOs.

et al., 2003; Kelemen and Dick, 1995; Nicolas, 1986; Quick, 1982; Suhr et al., 2003; Tommasi et al., 2006). Anisotropic melt distribution controlled by the deformation in the mantle is indicated by the parallelism between a diffuse compositional layering (plagioclase or clinopyroxene enrichment) and the foliation observed locally in the Lherz and Lanzo orogenic massifs (Higgie and Tommasi, 2014; Le Roux et al., 2008), at the crust-mantle transition zone in the Oman ophiolite (Boudier and Nicolas, 1995; Higgie and Tommasi, 2012; Jousselin et al., 2012), or in mylonitic xenoliths from Morocco (El Messbahi et al., 2015) and Hoggar (Kourim et al., 2014). These observations support a planar arrangement of the melt parallel to the shear plane with a periodicity ranging from a few $\mathrm{mm}$ to tens of $\mathrm{cm}$. However, the analysis of neither the microstructures nor the chemistry of these rocks constrains the instantaneous melt fraction in these systems, which is an essential parameter to constrain the associated anisotropy (Mainprice, 2007). Finally, melt extraction by dikes may also give rise to larger scale (tens of meters or larger) compositional layering if the regional stress field controls diking. A preferred orientation of melt-filled dikes has indeed been invoked to explain the strong rift-parallel seismic anisotropy in shallow lithospheric mantle and crust beneath the Afars (Hammond et al., 2014).

\section{Consequences for the evolution of the lithospheric mantle and for plate tectonics}

\subsection{Thermal heterogeneity}

Thermal heterogeneity is very effective in producing strength gradients due to the exponential dependence of the viscoplastic (ductile) deformation on temperature. Lateral variations of the geothermal gradient within plates are therefore a first order source of rheological heterogeneity, controlling strain localization at the plate tectonics scale. The most obvious thermo-rheological heterogeneities are cratons, with their thick and cold lithospheric roots. Already in the early 80s, Molnar and Tapponnier (1981) proposed that variations in the thermal structure, controlled by the age of the last orogenic episode affecting the crust, might explain the heterogeneous strain distribution in Asia in response to the India collision. This hypothesis was corroborated by numerical models, which showed that an older and stiffer block embedded in a collision zone, such as the Tarim block in the Himalayas, remains roughly undeformed and produces strain localization around it (England and Houseman, 1985; Vilotte et al., 1984). Thermal heterogeneity may thus explain the general structure of continental plates, which are usually formed by collisional zones of various ages molding a few cratonic nuclei. A spectacular example of this process is the fossil Meso- and Neoproterozoic orogenic belts and the active East African rift that wrap around the Tanzanian craton in eastern Africa (Fig. 12). Another, less evident effect of large-scale stiff heterogeneities within continental plates are stress concentrations at their tips, which, in a compressional field, may result in development of transpressional shear zones that propagate several hundreds of $\mathrm{km}$ into the plate interiors (Tommasi et al., 1995; Vauchez et al., 1998). Such a model may, for instance, explain the transpressional deformation (Fig. 13) in the Neoproterozoic Ribeira belt in southeast Brazil (Vauchez et al., 1994) or in the Great Slave shear zone in Canada (Hanmer et al., 1992; Hoffman, 1987). It may also account for the development of the Baikal rift in a regional compressive setting, which follows the southern boundary of the Siberian craton (Lesne et al., 1997; Petit and Deverchere, 2006).

Soft rheological heterogeneities associated with hotter than average geotherms may also localize strain. Dunbar and Sawyer (1988) showed, for instance, that, in a plate submitted to extension, higher temperatures in the sub-Moho mantle due to local crustal thickening result in localized thinning of the lithospheric mantle. Extensional basins (aborted 


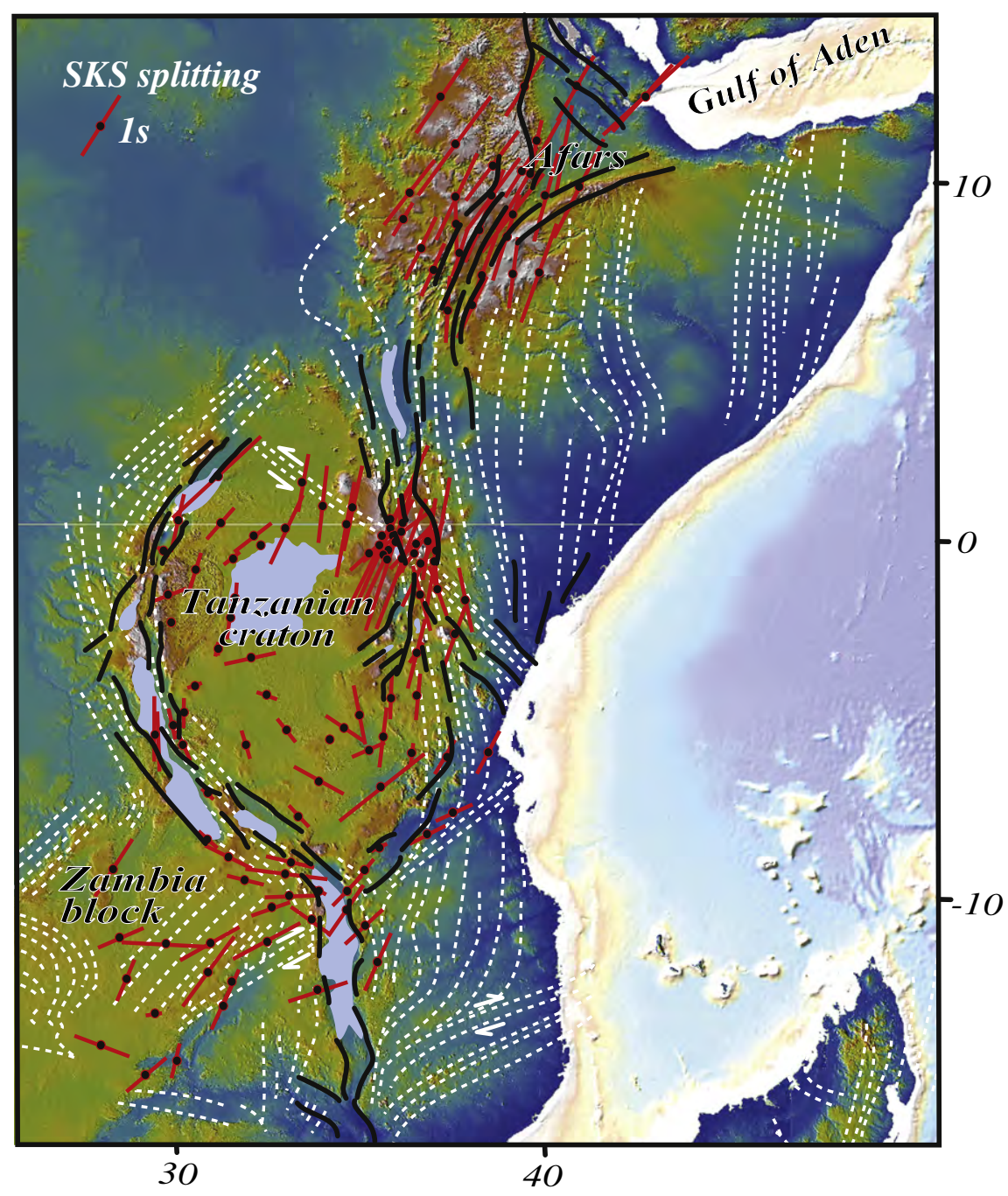

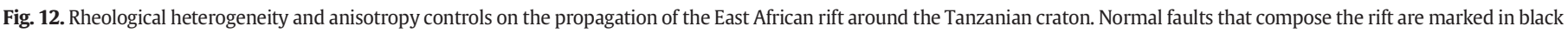

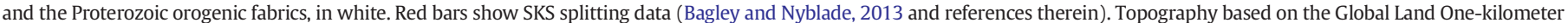
Base Elevation (GLOBE) Digital Elevation Model, Version 1.0. from the National Oceanic and Atmospheric Administration, National Geophysical Data Center via GeoMapApp. http://www.geomapapp.org.

rifts) within a continental plate may also localize subsequent deformation, if the thermal anomaly produced by the lithospheric thinning is not completely relaxed (Tommasi et al., 1995). This may explain the development of intraplate orogenic belts, such as the High and Middle Atlas in Morocco, which reactivate transtensional rifts formed during the opening of the central Atlantic (Beauchamp et al., 1996; Schettino and Scotese, 2002; Schettino and Turco, 2009). The presence of several soft heterogeneities in a plate may lead to development of complex systems, since strike slip shear zones develop to transfer deformation between the different heterogeneities (Tommasi and Vauchez, 1997; Tommasi et al., 1995). Such a model was proposed, for instance, to explain the formation of the Neoproterozoic Borborema shear zone system in NE Brazil. This system is characterized by an association of E-W dextral shear zones up to $20 \mathrm{~km}$ wide, which branch from a major NE-SW strike-slip shear zone and terminate in transpressional volcanosedimentary belts with orientations ranging from N-S to NE-SW (Vauchez et al., 1995). An inversion of rheological behavior of an intracontinental rift, from soft to stiff, due to thermal relaxation (cooling), may on the other hand explain why older volcanosedimentary belts in the same region behaved as stiff structures during this deformation (Tommasi and Vauchez, 1997). A similar process has been proposed to explain the strong lateral heterogeneity in the thermo-mechanical evolution of the Variscan belt in Bohemia (Štipská et al., 2001).

Interplay between deformation localized in lithospheric-scale weak rheological heterogeneities (thin spots) and stress concentration in the upper crust has also been proposed as a possible explanation for the distribution of intraplate seismicity in South America based on the spatial relation between seismically active domains and low P-wave velocities at 150-200 km depth (Assumpção et al., 2004). Similarly, a hotter than normal lithospheric mantle has been proposed to account for the New Madrid Seismic zone in the eastern USA on the basis of surface heat flow data (Liu and Zoback, 1997). The low velocity anomaly (up to 6\%) imaged by P-wave tomography between 80 and $200 \mathrm{~km}$ depth beneath the New Madrid Seismic zone corroborates this model (Chen et al., 2014).

Weak rheological heterogeneities may also be produced by a slight enhancement in the heat production due to metasomatism, leading to enrichment in radiogenic elements in the lithospheric mantle. Numerical models show that a radioactive heat production of $0.1(0.25) \mu \mathrm{W} / \mathrm{m}^{3}$ in a $200 \mathrm{~km}$ wide layer between 60 and $80 \mathrm{~km}$ depth may result in local strain rates up to 2 (5) times higher than in the surroundings (Neves et al., 2008). Due to slow radioactive decay, these soft heterogeneities may be preserved for several hundreds of m.y. 

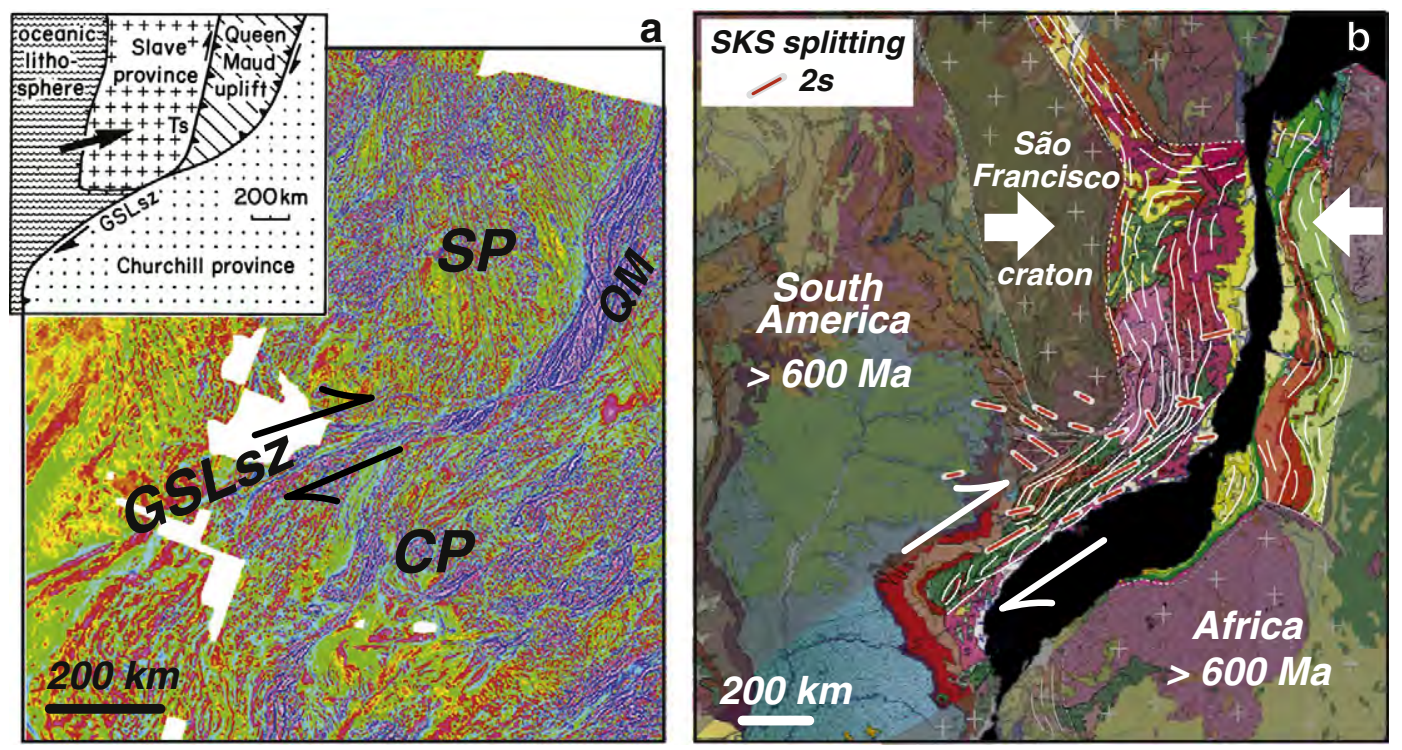

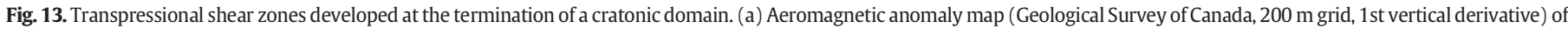

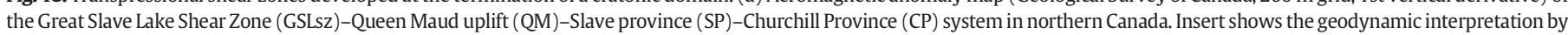

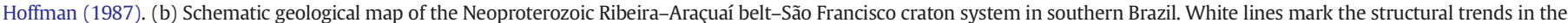
Neoproteroic belts, to which are superimposed the existing SKS splitting data (Assumpção et al., 2006, 2011; Heintz et al., 2003).

Melt percolation may also produce heating and favor strain localization, but at much smaller scales and shorter times. Microstructural observations and thermobarometric data in mantle xenoliths from beneath the active East African rift in Tanzania (Baptiste et al., 2015) and the $4^{\circ} 50^{\prime}$ shear zone in Hoggar (Kourim et al., 2015) are consistent with short-lived melt-related heating events. Advective heating by migrating magmas might affect larger volumes of the lithosphere in case of continued magmatic activity. Heating of the lithospheric mantle and crust by migration of hot mantle fluids focused in Precambrian lithospheric shear zones has been invoked, for instance, to explain the shallow Curie temperatures, which imply temperatures of $>500^{\circ} \mathrm{C}$ at depths of 8-15 km, and high heat flows $\left(60-90 \mathrm{~mW} \mathrm{~m}^{-2}\right)$ observed in the incipient Okavango Rift Zone in southern part of the East African rift (Leseane et al., 2015). However, though it may be important atop plumes and in arcs, the actual contribution of heat advection by migrating melts in heating the lithosphere is still poorly constrained.

Finally, combined perturbations of the thermal and stress fields within a plate produced by an upwelling plume hitting the lithosphere may have far field effects. They may work as attractors inducing fast rift propagation, as during the South Atlantic opening, where the rift propagated rapidly from the Agulhas basin towards the Parana plume following the trend of Neoproterozoic collisional belts (Courtillot et al., 1999; Lawyer et al., 1985; Tommasi and Vauchez, 2001). A similar evolution occurred in the Gulf of Aden, formed by fast propagation of a new ridge from the Carlsberg ridge in the Northwest Indian Ocean towards the Afar plume (Courtillot et al., 1999; Fournier et al., 2010). Although in a less advanced stage, the propagation of the East African rift towards the plume currently beneath the eastern boundary of the Tanzanian craton (Chorowicz, 2005) suggests a similar process.

\subsection{Compositional heterogeneity}

In a fully solid mantle - the prevailing state in the lithosphere - the question is whether the lithological contrasts commonly observed in peridotite massifs (essentially local enrichment in pyroxenes or olivine) significantly change the rheology of mantle rocks. In other words, does a refractory peridotite have a higher strength than a fertile one? Experimental data on olivine-pyroxenes mixtures predict that enrichment in pyroxene weakens the aggregates (Ji et al., 2001; Sundberg and Cooper, 2008; Tasaka et al., 2013). However, all these experiments were performed on well-mixed, very fine-grained synthetic aggregates, that is, on microstructures very different from those commonly observed in naturally deformed peridotites. The extrapolation of these data to the lithospheric mantle is therefore subject to caution. In peridotite massifs, the common boudinaged and folded pyroxenite layers (Fig. $4 \mathrm{f}$ and top panel of Fig. 6) suggest that pyroxenites are more competent than peridotites under a large range of conditions. Based on a dynamic instability analysis of folded and boudinaged orthopyroxenite dykes in the Twin Sister peridotite massif, Tikoff et al. (2010) estimated that the pyroxenites were $\sim 25$ times more viscous than the surrounding harzburgites. The lack of boudinage in the harzburgite-pyroxenite series in Oman (Boudier and Coleman, 1981) and in the websterites of the coarse-granular domains in the Beni Bousera massif (Frets et al., 2014) suggests that this contrast may decrease at high temperature. Evidence for a lower strength of pyroxenitic layers in naturally deformed peridotites is nevertheless limited to rare kimberlite-borne mylonitic xenoliths, in which pyroxene-rich layers composed of recrystallized grains a few microns wide localize strain, but this strain localization is probably due to the smaller recrystallized grain sizes of pyroxene (Boullier and Gueguen, 1975). Observations on naturally deformed peridotites also do not provide any evidence for marked strength contrasts between dunites, harzburgites, and lherzolites. Layered lherzolite-harzburgite or harzburgite-dunite series are usually not boudinaged and show no evidence for strain localization across the layering (e.g., Boudier and Coleman, 1981; Niida, 1984; Tikoff et al., 2010; Tommasi et al., 2006). Analysis of the microstructures of naturally deformed peridotites also indicates that, except in mylonites deformed under high-stress conditions, pyroxene crystals are systematically less elongated and less recrystallized than the surrounding olivine. This suggests that in peridotites olivine forms a continuous network that accommodates most strain and that other mineral phases do not play a major role in deformation. Altogether, observations on naturally deformed peridotites suggest that variations in the olivine content, though common in the lithospheric mantle, do not result in significant mechanical heterogeneity.

In contrast, more subtle changes in the peridotites chemistry due to metasomatism, such as an enhancement in heat-producing elements, which was discussed in the previous section, or a variation in the hydration state of olivine, might have a significant effect on the lithospheric mantle deformation. Dehydration of olivine due to partial melting has, indeed, often been proposed to account for high viscosities in cratonic 
roots (e.g., Doin et al., 1997; Lenardic et al., 2003). The actual consequences of hydrogen incorporation on the olivine rheology are, however, still discussed. Commonly used flow laws predict that hydrogen incorporation in olivine may result in decrease in strength by up to two orders of magnitude, with strain rates increasing approximately linearly with water concentration (Hirth and Kohlstedt, 2003). These predictions however should be taken with caution since they are based on extrapolation of the moderate weakening (up to a factor 2) observed in deformation experiments on wet olivine single crystals and polycrystals at $300 \mathrm{MPa}$ (Chopra and Paterson, 1984; Karato et al., 1986; Mei and Kohlstedt, 2000) to the higher water contents that might exist at higher pressure in the mantle. High-pressure deformation experiments on hydrated olivine single crystals (4740-11,770 ppm wt $\mathrm{H}_{2} \mathrm{O}$ ) show, however, less than a factor 2 decrease in strength relatively to dry conditions (Girard et al., 2013; Mackwell et al., 1985). Diffusion experiments under high-temperature and high-pressure conditions also suggest that incorporation of hydrogen has a weak effect on Si diffusion in olivine, which is considered to be the rate-controlling mechanism for both diffusion and dislocation creep in the mantle (Fei et al., 2013).

Several other issues arise when extrapolating data from deformation experiments on wet olivine polycrystals to nature. In which form is the water during the experiments? Is it present only as $\mathrm{H}^{+}$incorporated in the olivine structure or also as free water along grain boundaries, as suggested by Demouchy et al. (2012). Which is the actual hydration state of the mantle? The range of water contents measured in natural olivine crystals (0-200 ppm wt $\mathrm{H}_{2} \mathrm{O}$, Peslier et al., 2010; Baptiste et al., 2012; Doucet et al., 2014) may only produce moderate variations of the peridotite viscosity (less than a factor 10, Hirth and Kohlstedt, 2003). These data point to another problem in explaining the stability of cratonic roots by dehydration of olivine. The highest water contents in olivine were measured in mantle xenoliths from the thick and old Kaapvaal and Siberian cratons. They probably record hydration associated with the multiple metasomatic events that affected these mantle roots since their formation (Baptiste et al., 2012; Doucet et al., 2014; Peslier et al., 2010). Yet, although this hydration must have occurred before the extraction of the xenoliths by the kimberlitic magmatism in the Mesozoic, both cratonic roots are still stable.

Magmatic rejuvenation coupled to small-scale convection has been proposed as an alternative process to explain the rupture of the North American craton to form the Labrador Sea (Foley, 2008). This model involves a succession of reactive melt percolation events, which progressively modify the composition and density of the lithosphere until a continuous network of "impregnated or metasomatized" mantle rocks is formed. It requires multiple focused melt percolation events that may be spaced by several m.y. It also implies that the resulting change in physical properties suffices for destabilizing the mantle root. These two points require further testing.

On the other hand, magmatic refertilization by reactional percolation of basaltic melts, as observed in the Lherz and Ronda peridotite massifs (Le Roux et al., 2007; Soustelle et al., 2009), does facilitate melting at the base of the lithosphere. The presence of melt may locally weaken the base of the lithospheric mantle. Experimental data show that a few percent of melt results in reduction by up to a factor 10 in the strength of the peridotites (Kohlstedt and Zimmerman, 1996). Melt-induced weakening is also suggested by the localization of shear zones within dunites in peridotite massifs (Kelemen and Dick, 1995; Kruckenberg et al., 2013). Upwelling of the lithosphere-asthenosphere boundary may thus occur through a progression of melt percolation fronts, followed by deformation and partial melting fronts.

\subsection{Variations in grain size}

If grain-size sensitive processes play a role in the deformation, variations in grain size may result in marked strength gradients (Poirier, 1980). Grain size reduction is indeed, together with shear heating, the most commonly invoked processes to explain strain localization in the ductile regime (e.g., De Bresser et al., 2001; Kirby, 1985; Platt and Behr, 2011; Poirier, 1980; White et al., 1980). Localized grain size reduction is, for instance, at the core of the damage model proposed by Bercovici and Ricard (2014) to explain the existence of plate tectonics on Earth. Essential assumptions in this model are that small grain sizes may be preserved for very long time spans ( $\gg$ tens of m.y.) and that the volumes of "damaged", that is, fine-grained rocks are large enough to produce effective strain localization at the plates scale.

Many models investigated the conditions under which strain localization by grain size reduction may be effective in the Earth mantle (e.g., Bercovici and Ricard, 2012; Braun et al., 1999; Kameyama et al., 1997; Rozel et al., 2011). These models studied the interplay between grain size reduction by dynamic recrystallization and grain growth both during and after deformation. They analyzed the dependence of these processes on the strain rate, the temperature, the mean grain size, the grain size distribution, and the effect of second (pinning) phases. A first conclusion was that, in absence of second phases, strain localization by grain size reduction is restricted to deformation coeval with cooling (Braun et al., 1999). This prediction is consistent with the usual association of grain size reduction with strain localization in retrograde shear zones. These numerical models also showed that, in an olivine-only system, preservation of very fine grain sizes for geological time spans ( $\gg$ m.y.) is limited to cold domains of the lithospheric mantle, where the grain growth kinetics is slow (Rozel et al., 2011).

Zener-pinning by second phases (pyroxenes and Al-rich phases in the lithospheric mantle) may, however, block grain growth even at high temperatures, favoring the preservation of fine-grained domains (Bercovici and Ricard, 2012). The efficiency of this process depends nevertheless on the grain size and distribution of the second phase; it is maximized for homogeneously distributed fine-grained pyroxenes, as in the synthetic aggregates used in experiments (cf. review by Herwegh et al., 2011). However, as reviewed in Section 3.3, such microstructures are only observed in nature within mm-scale ultramylonite bands in which synkinematic reactions trigger crystallization of finegrained phases. In most peridotites, pyroxene grains or pyroxene-rich domains show mm-scale spacing (cf. EBSD phase maps in Fig. 6). Even in mylonitic peridotites, where both phases are largely recrystallized, shearing results in phase-segregation and the spacing between pyroxene-rich domains is on average $\gg 100 \mu \mathrm{m}$ (Fig. 9). These observations suggest that pinning is not an effective process to preserve small grain sizes for geological times in large volumes of mantle rocks.

In addition, natural observations point to effective grain size reduction in small volumes of the lithospheric mantle. Peridotite mylonites, i.e., partially recrystallized rocks with average grain sizes $<200 \mu \mathrm{m}$ and microstructural evidence for dominant dislocation creep, occur essentially within shear zones with a maximum width of a km (usually $\leq 100-$ $200 \mathrm{~m}$ ). These microstructures may be preserved for long time spans only in the colder, shallowest parts of the lithospheric mantle. The volumes of ultramylonites are even smaller. They are limited to $\mathrm{mm}$ to $\mathrm{cm}$ scale bands spaced by a few $\mathrm{cm}$ in mylonitic domains a few meters to hundred meters wide. Yet reactional ultramylonites are the sole rocks displaying clear evidence for phase mixing and, hence, in which pinning may inhibit grain growth over very long time spans. Strain localization may be associated with the reactivation of these fine-grained domains. These mylonitic and ultramylonitic zones may also accommodate significant amounts of shear, consistent with plate tectonic slip rates. The open question is whether their volume and/or spatial distribution (do they form networks continuous over long enough distances?) suffice to produce effective strain localization at the plates scale as proposed by Bercovici and Ricard (2014). In other words, do hundred of meters wide and a few $\mathrm{km}$ long rheological heterogeneities confined to the shallow part of the lithospheric mantle represent large enough perturbations to trigger plate scale strain localization? New models considering explicitly the thermal gradient across a plate, its effect on grain growth, and in which the effect of grain size pinning is not overestimated are needed to answer this question. 


\subsection{Thermo-mechanical anisotropy}

Anisotropy associated with coherent preferred orientation of olivine crystals directly modifies the thermo-mechanical behavior of the mantle, since it induces a directional dependence for both elastic and viscoplastic deformations and for the thermal conduction. Viscoplastic anisotropy modifies the flow pattern, because deformation in some directions will be easier. Numerical models of the deformation of a homogenous, but anisotropic plate composed of $100 \%$ olivine (Knoll et al., 2009) show that, depending on the deformation regime and on how the CPO evolves with strain, viscoplastic anisotropy may produce hardening (in compression or extension) or softening (in simple shear). Hardening (increase in yield stress by a factor 2) has also been documented experimentally by deforming in axial extension olivine polycrystals previously deformed in simple shear to different strains (Hansen et al., 2012).

Yet, the lithospheric mantle is not a homogeneous anisotropic medium. As reviewed in Section 2.2, seismic anisotropy data reveal that anisotropy is ubiquitous, but the orientation of fast seismic directions and hence the orientation of the olivine CPO change laterally both at plate boundaries and within plates (Figs. 2, 3, 12,13). Lateral variations in upper mantle viscoplastic anisotropy may control the strain distribution, because deformation will tend to be focused in domains where the preexisting olivine $\mathrm{CPO}$ (inherited from previous deformation events) is well oriented to accommodate the present tectonic solicitation. Numerical models of the extensional deformation of a plate containing a planar domain with a moderate olivine CPO oriented as to simulate a preexisting continental scale strike-slip shear zone embedded in an initially isotropic plate show that such structures are reactivated (i.e., they localize the deformation) when submitted to compression or extension oblique to their trend (maximum resolved shear stresses on the preexisting fabric are obtained for compression or extension at $45^{\circ}$; Fig. 14), but display a stiff behavior for both compression and extension normal or parallel to the preexisting foliation (Tommasi et al., 2009). A characteristic feature of the reactivation of these 'fossil shear zones' is that it implies, in its initial stages, a strong component of shearing parallel to the foliation in the fossil shear zone (Fig. 14e-g).

The predictions of these models are consistent with observations suggesting transtension followed by normal extension in many active or fossil rift systems that formed parallel to ancient collisional belts, such as the East African rift (Bosworth and Strecker, 1997), the Rhine graben (Homuth et al., 2014; Schumacher, 2002), and the rifts leading to the break-up of eastern Gondwana (Jacob and Dyment, 2014; Powell et al., 1988) and the opening of the North Atlantic (Geoffroy et al., 1994). These models also explain the common reactivation of large-scale wrench faults during successive collisional and extensional episodes. For instance, the Newfoundland-Azores-Gibraltar fault zone, which acted as a dextral strike-slip boundary during the Hercynian orogeny (Keppie, 1989), was reactivated as a major transform fault accommodating the differential motion between Africa and Europe during the opening of the Central Atlantic (Fig. 15). A similar process may explain the formation of transtensional rifts along the Paleozoic Atlas belt in Morocco in the same period and their reactivation in compression during the Neogene to produce the High and Middle Atlas mountains (Beauchamp et al., 1996; Schettino and Scotese, 2002; Schettino and Turco, 2009).

The evolution of the olivine CPO with increasing strain both within and outside the 'inherited shear zone' may, however, result in inversion of the rheological contrast between the 'inherited shear zone' and its surroundings, leading to strain delocalization (Tommasi et al., 2009). Comparison of the evolution of the strain rate in three models that only differ by the initial olivine CPO outside the inherited shear zone illustrates this effect (Fig. 14b-g). Delocalization does not occur in the model where the initial olivine CPO outside the 'inherited shear zone' is oriented with the maximum concentration of [100] parallel to the imposed extension, because this initial hard orientation is strengthened by the extension (Fig. 14c and f). In the model with an initially random olivine $\mathrm{CPO}$, the CPO evolution in both domains result in hardening, but this evolution is faster in the 'inherited shear zone' producing strain delocalization for extensional strains of 25\% (Fig. 14b and e). Delocalization is even faster in the model where the initial olivine CPO outside the 'inherited shear zone' is oriented with the maximum concentration of [100] normal to the imposed extension, because this initially hard orientation is unstable (Fig. 14d and g). The CPO reorientation outside the inherited shear zone results in weakening, whereas the evolution of the olivine CPO inside the inherited shear zone produces hardening.

Failed rifts are common in nature, among which many are parallel to the preexisting fabric of the plate, such as the Mesozoic Tucano-Jatoba basins in Brazil, which closely follow the $\mathrm{N}-\mathrm{S}$ archean structures in the São Francisco craton and the Neoproterozoic East Pernambuco shear zone north of it (Milani and Davison, 1988). However, many rifts evolved into successful oceanic basins. This suggests that, in these systems, either the CPO evolution during extension did not result in an inversion of the rheological contrasts or other softening processes, such as shear heating, changes in microstructure, and/or focusing of melts or fluids into the deformed zones, have been activated to keep the deformation localized into the nascent rift.

Based on these model results and on geological observations, Tommasi et al. (2009) proposed that lateral variations in mechanical behavior due to changes in the inherited olivine crystal preferred orientations within a plate represent a major 'seed' process for strain localization. In contrast to lateral variations of the geotherm, crustal thickness, or damage zones associated with brittle faults that may also seed localization, the persistence of viscoplastic anisotropy is not limited by heat diffusion, isostatic re-equilibration, or erosion. As discussed in the previous sections, olivine CPOs are the rule, not the exception in the lithospheric mantle. Once formed, CPO is not destroyed, but only modified by new deformation episodes. The coherence between seismic anisotropy data and the orientation of crustal structures in geological terranes of different ages, including cratons (e.g., Mareschal et al., 1995; Silver and Chan, 1991; Silver et al., 2001), corroborates that CPO-induced mechanical anisotropy may be preserved for billions of years. Viscoplastic anisotropy due to preexisting crystallographic fabric may therefore be reactivated long time after the cessation of the deformation event that produced it. It may thus be the main cause of repeated opening and closure of oceanic basins along the same suture zones - the Wilson cycles (Wilson, 1966).

However, the models discussed above considered a highly simplified situation, in which the olivine deformation and the resulting CPO evolution do not depend on temperature. The conditions implemented in the models are appropriated to simulate the high-temperature deformation in the lower part of the lithospheric mantle, but their applicability to model the deformation in the cold sub-Moho lithospheric mantle is disputable. Experimental data suggest that at temperatures $<1000^{\circ} \mathrm{C}$, deformation of olivine activates both [100] and [001] glide in multiple planes (Demouchy et al., 2013, 2014; Phakey et al., 1972). This should result in weaker olivine $\mathrm{CPO}$ and reduce the anisotropy. In addition, the observations reviewed in Section 3.3 suggest that, at low temperature, deformation in the lithospheric mantle is localized in very small volumes. These two points are at odds with the seismic anisotropy detected by refraction and Pn studies in most continental domains and, in particular, beneath major fossil and active strike slip shear zones, such as the San Andreas and Alpine transform boundaries or the hercynian South Armorican shear zone (e.g., Bamford, 1977; Buehler and Shearer, 2014; Calvert et al., 2000; Fuchs, 1977; Hearn, 1996; Hirn, 1977; Judenherc et al., 2003). Do the seismic anisotropy data imply that the deformation in these strike-slip zones produced 'hightemperature'-type olivine $\mathrm{CPO}$ in the shallow lithospheric mantle at scales of tens of $\mathrm{km}$ ? Or do they record an older higher temperature lithospheric deformation, the present-day deformation been localized in volumes too small to be sampled by seismic methods, as suggested by Behr and Hirth (2014) for the southern California? In the latter case, 

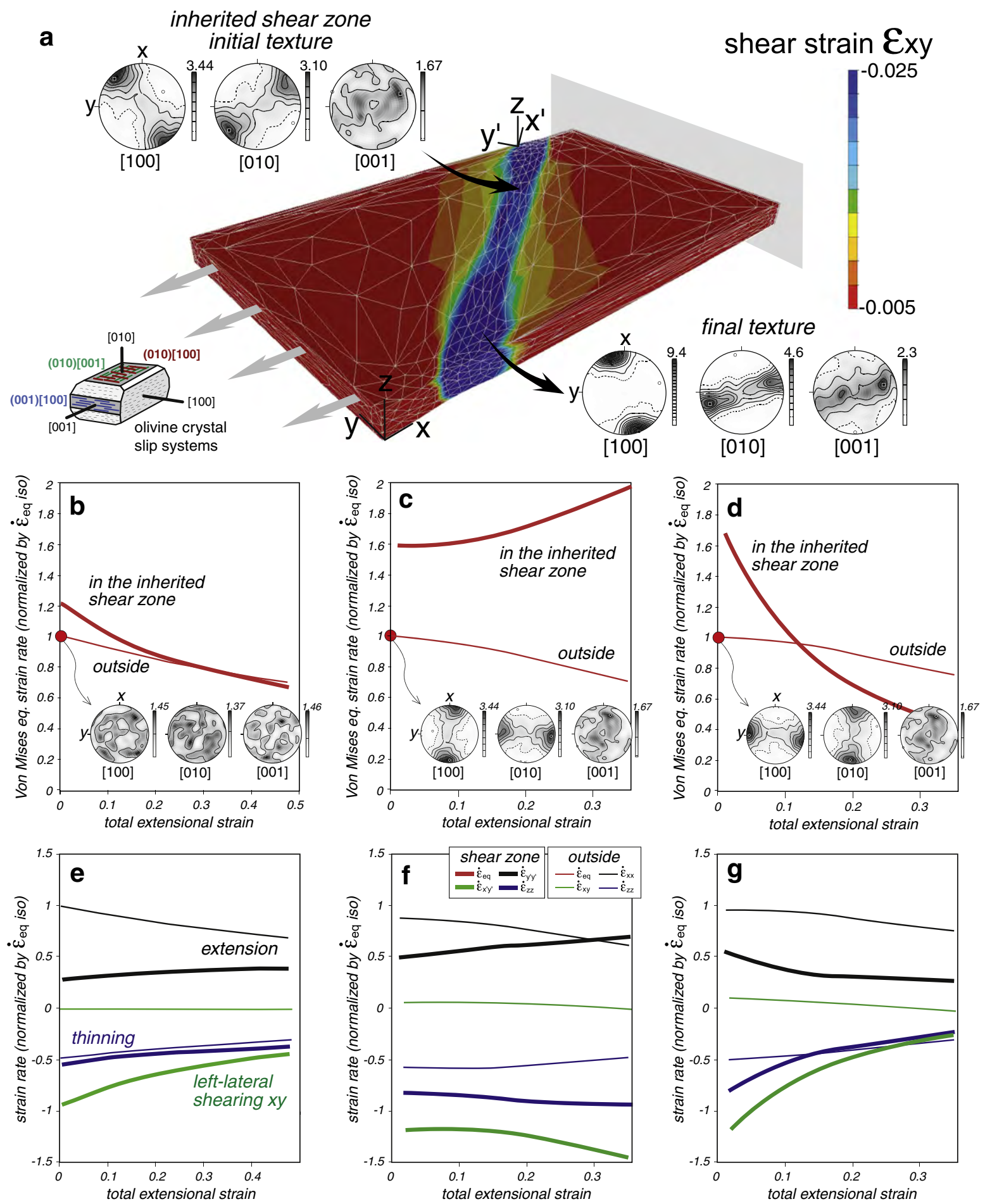

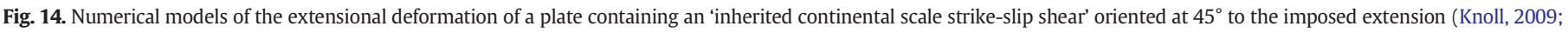

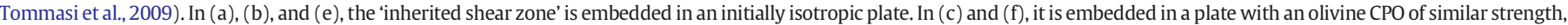

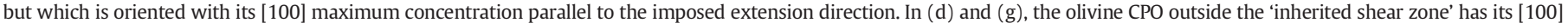

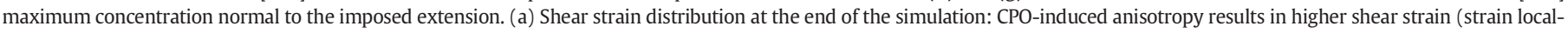

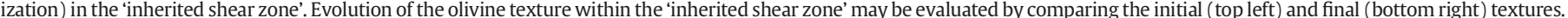

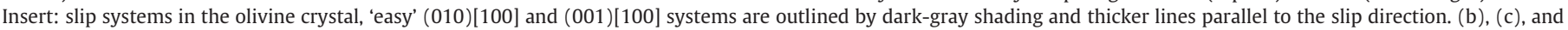

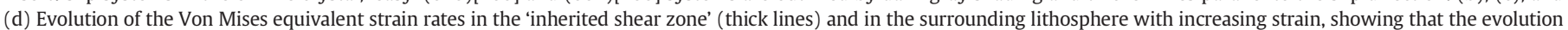

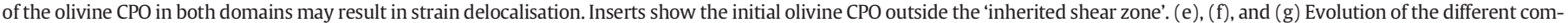
ponents of the strain rate tensor with increasing strain. Note the transtensional deformation within the inherited shear zone.

why are the seismic and tectonic observations coherent? These inconsistencies highlight our poor knowledge of the deformation in the uppermost lithospheric mantle, which hinders a proper representation of this key layer in models.
Heat conduction in mantle rocks also is anisotropic; experimental data show that conduction parallel to the lineation is up to $30 \%$ faster than normal to the foliation (Gibert et al., 2003; Tommasi et al., 2001). However, heat diffusion is a slow process and this anisotropy does not 


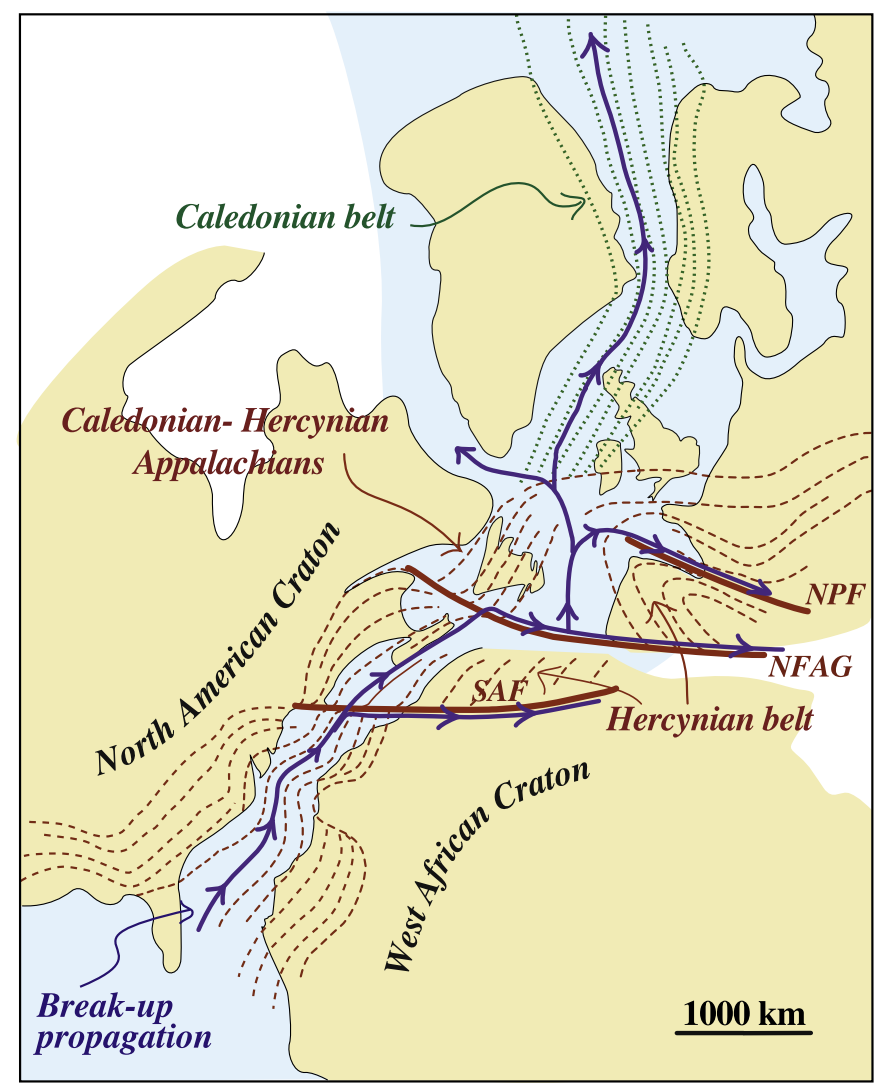

Fig. 15. Structural reactivation during the opening of the Central and North Atlantic ocean. Note the reactivation of major Hercynian shear zones, like the Newfoundland-AzoresGibraltar (NFAG), the South Atlas Fault (SAF), and the North Pyrenean Fault (NPF), as transform faults.

result in highly anisometric thermal anomalies. This process alone cannot therefore explain the reactivation of the preexisting fabric of the lithospheric mantle. However, it may assist strain localization due to viscoplastic anisotropy. A similar effect may be expected from an anisotropic arrangement of melt rich lenses. Since the presence of even small melt fractions results in weakening of mantle rocks (Kohlstedt and Zimmerman, 1996; Takei and Holtzman, 2009), a preferred orientation of melt lenses should result in mechanical anisotropy, leading to a reduced shear viscosity parallel to the orientation of the melt lenses (Holtzman et al., 2012). As discussed in Section 3.4, oriented melt lenses are produced by either ongoing deformation or anisotropic percolation along a preexisting foliation. If present, mechanical anisotropy due to melt alignment will therefore add up to the viscoplastic anisotropy produced by olivine CPO.

\section{Concluding remarks}

Joint analysis of geophysical observations and of meso- to micrometric scale structures on peridotite massifs and xenoliths indicates that heterogeneity and anisotropy are ubiquitous in the lithospheric mantle. Significant effects of heterogeneities and anisotropies on the physical properties and behavior of the lithospheric mantle are therefore expected. Several types and scales of heterogeneity have been evidenced:

1- Large-scale variations in the geothermal gradient, which may be accompanied by a variation in composition, as in the cratons. These heterogeneities are produced by major geodynamic processes (subduction, rifting, collisions, plume impacts) and are active over protracted time durations. Some of these thermal heterogeneities, like the cratons, may remain stable for several G.y., while others, like aborted rifts, are transient and may be re-equilibrated after a few tens of m.y. These stiff (cold) or soft (hot) domains, which are hundreds to thousands of $\mathrm{km}$ wide, form a first order mechanical heterogeneity pattern that controls the strain distribution within plates.

2- Strong heterogeneity in both major-element and modal compositions occurs at all scales in the lithospheric mantle, starting at the $\mathrm{mm}$ - to m-scale (e.g., the compositional layering observed in most peridotite massifs). This compositional heterogeneity, which is essentially produced by reactive melt migration in the lithospheric mantle, is a very long-lived feature. Solely melting produces homogenization; deformation only decreases the scale of heterogeneity. Heterogeneity in the mineralogical composition has nevertheless a minor effect on the mechanical behavior of the lithospheric mantle, as indicated by the absence of evidence for rheological contrasts between dunites, harzburgites, and lherzolites in peridotite massifs. However, it has a strong effect on the melting behavior and might indirectly (via localized melting) affect the strain repartition.

3- Presence of small fractions of melt may result in strong local weakening and in marked seismic and mechanical anisotropy if the melt is contained in oriented lenses or pockets. However, this meltrelated weakening and anisotropy are transient effects, which disappear with melt crystallization or extraction.

4- Variations on the hydration state of the lithospheric mantle, in particular $\mathrm{H}^{+}$incorporation in olivine, might also result on rheological heterogeneity, but the actual effect of hydration on the olivine deformation is presently unclear. Moreover, the hydration state of the lithospheric mantle seems to be not exclusively controlled by partial melting, but also by exchanges with fluids and melts percolating the lithosphere, which are still poorly understood.

5- Rheological heterogeneity may arise from grain size reduction. Inherited grain size heterogeneity may thus favor tectonic reactivation. The key question is whether the volumes of fine-grained peridotites present in the lithospheric mantle suffice to modify the rheology of the plates. Observations in peridotite massifs indicate that fine-grained (mylonitic) peridotites are restricted to shear zones $<1 \mathrm{~km}$ wide. Further grain size reduction up to a few microns is reached in still smaller volumes: $\mathrm{cm}$ - to $\mathrm{mm}$-wide ultramylonite bands heterogeneously distributed in the coldest parts $(\leq 100 \mathrm{~m}$ wide) of these shear zones. Grain size heterogeneity is destroyed by grain growth, which depends on temperature, time, and on the size and distribution of second phases (pinning). Grains sizes $<50 \mu \mathrm{m}$ may only be preserved for several hundreds of m.y. in the shallow and coldest parts of the lithospheric mantle or within $\mathrm{cm}$-scale ultramylonite bands in which reactional processes have produced effective phase mixing allowing for grain boundaries pinning.

6- Last but not least, another major source of rheological contrast and hence of strain localization within plates is the variation in the viscoplastic anisotropy due to lateral changes in the orientation of the olivine CPO. This anisotropy results in easier shearing parallel to dominant orientation of the olivine easy slip system, leading to reactivation of preexisting structures when the resolved shear stress on their foliation planes is high.

Olivine CPOs are formed and modified by deformation. Since the mantle has been solid and deforming (either by convection or, at lithospheric depths, in response to plate tectonics) for $>4$ G.y., crystallographic preferred orientation of olivine and other mantle minerals is the rule. Thus CPO-induced elastic and viscoplastic anisotropy exists everywhere. Though CPOs are produced at the rock (polycrystalline aggregate) scale, the length scale at which anisotropy is effective depends on the scales at which deformation with a similar kinematics occurs. In other words, it depends on the volumes of lithospheric mantle deformed in a consistent way during a tectonic event. The consistency of 
shear wave splitting measurements in continental domains suggests that olivine CPO may have coherent orientations at scales ranging from tens to hundreds of $\mathrm{km}$. However, seismic anisotropy measurements also record sharp changes in the orientation of anisotropy, which are associated to superimposed tectonics events or to strain partitioning at the scale of the tectonic system.

Numerical models, which explicitly consider an evolving mechanical anisotropy due to olivine $\mathrm{CPO}$ in the lithospheric mantle show that: (i) this anisotropy changes the mechanical response of the plates, leading to non-parallelism between applied stresses and deformation and to development of shearing parallel to the preexisting structures trend and (ii) lateral variations in the orientation and strength of olivine $\mathrm{CPO}$ result in mechanical contrasts, which may seed strain localization. Different evolution of the olivine CPO with increasing strain in the various domains of the models may, however, result in inversion of the rheological contrast, leading to strain delocalization. In nature, however, activation of other strain localization mechanisms may impede delocalization.

An open question in predicting mechanical anisotropy in the lithospheric mantle is our poor knowledge on how the lithospheric mantle deforms in convergent or extensional plate boundaries (actual deformation regime, strain repartition, presence or not of shear zones, and, if yes, their orientation and kinematics). Using seismic anisotropy data, we may infer the volumetrically dominant olivine $\mathrm{CPO}$, but not the strain distribution. Higher strain localization, producing thinner deformed and, hence, anisotropic domains, is expected in cold parts of the lithospheric mantle. In these domains, olivine CPO patterns might therefore vary over shorter length scales ( $\leq 1 \mathrm{~km})$. In addition, mylonitic and ultramylonitic peridotites have dominantly weak olivine $\mathrm{CPO}$ and hence a weak anisotropy, but they may preserve small grain sizes if temperatures are low. Thus, in cold domains of the shallow lithospheric mantle, grain size variations might add up to the $\mathrm{CPO}$-induced thermomechanical anisotropy (formed by high-temperature deformation at deeper levels or frozen in the host-rocks of the low-temperature shear zones) to produce strain localization.

\section{Acknowledgments}

We thank T. Horscroft for inviting us to write this review. W. Behr and an anonymous reviewer are thanked for their constructive reviews. David Mainprice is sincerely thanked for continuously sharing his expertise on the vast subjects of anisotropy and deformation on Earth in the last 25 years. The section on compositional heterogeneity benefited from countless discussions with Jean-Louis Bodinier, Sylvie Demouchy, and many other colleagues from Geosciences Montpellier. The mechanical anisotropy models would not exist without the collaboration of Javier Signorelli. Fatna Kourim is warmly acknowledged for providing the EBSD map shown on Fig. 9. Last but not least, we thank our past Ph.D. students and postdoctoral fellows, whose research projects constituted the foundation of many of the ideas developed in this article: Roberto Agrusta, Virginie Baptiste, Mickael Bonnin, Guilhem Coromina, Mathieu Duclos, Hicham El Messbahi, Gyorgy Falus, Erwin Frets, Alexander Gatzemeier, Benoit Gibert, Maggy Heintz, Karoly Hidas, Katherine Higgie, Mary-Alix Kaczmarek, Mickael Knoll, Fatna Kourim, Véronique Le Roux, Luis Morales, Vincent Soustelle, and Claudia Zaffarana.

\section{References}

Abers, G., Fischer, K., Hirth, G., Wiens, D., Plank, T., Holtzman, B., McCarthy, C., Gazel, E. 2014. Reconciling mantle attenuation-temperature relationships from seismology, petrology, and laboratory measurements. Geochem. Geophys. Geosyst. 15, 3521-3542.

Abramson, E.H., Brown, M., Slutsky, L.J., Zaug, J., 1997. The elastic constants of San Carlos olivine up to 17 GPa. J. Geophys. Res. 102 (12) $(12,252-212,263)$.

Abt, D.L., Fischer, K.M., French, S.W., Ford, H.A., Yuan, H., Romanowicz, B., 2010. North American lithospheric discontinuity structure imaged by Ps and Sp receiver functions. J. Geophys. Res. 115, B09301. http://dx.doi.org/10.1029/2009JB006914.
Adetunji, A.Q., Ferguson, I.J., Jones, A.G., 2015. Reexamination of magnetotelluric responses and electrical anisotropy of the lithospheric mantle in the Grenville Province, Canada. J. Geophys. Res. 120, 1890-1908.

Afonso, J.C., Fernández, M., Ranalli, G., Griffin, W., Connolly, J., 2008. Integrated geophysical-petrological modeling of the lithosphere and sublithospheric upper mantle: methodology and applications. Geochem. Geophys. Geosyst. 9, Q05008.

Agrusta, R., Arcay, D., Tommasi, A., Davaille, A., Ribe, N., Gerya, T., 2013. Small-scale convection in a plume-fed low viscosity layer beneath a moving plate. Geophys. J. Int. 194, 591-610.

Aizawa, Y., Barnhoorn, A., Faul, U.H., Gerald, J.D.F., Jackson, I., Kovács, I., 2008. Seismic properties of Anita Bay dunite: an exploratory study of the influence of water. J. Petrol. 49, 841-855.

Alsina, D., Snieder, R., 1995. Small-scale sublithospheric continental mantle deformation: constraints from SKS splitting informations. Geophys. J. Int. 123, 431-448.

Arcay, D. Tric, E. Doin, M.P. 2005. Numerical simulations of subduction zones: effect of slab dehydration on the mantle wedge dynamics. Phys. Earth Planet. Inter. 149, 133-153.

Assumpção, M., Schimmel, M., Escalante, C., Roberto Barbosa, J., Rocha, M., Barros, L.V., 2004. Intraplate seismicity in SE Brazil: stress concentration in lithospheric thin spots. Geophys. J. Int. 159, 390-399.

Assumpção, M., Heintz, M., Vauchez, A., Silva, M.E., 2006. Upper mantle anisotropy in SE and Central Brazil from SKS splitting: evidence of asthenospheric flow around a cratonic keel. Earth Planet. Sci. Lett. 250, 224-240.

Assumpção, M., Guarido, M., van der Lee, S., Dourado, J.C., 2011. Upper-mantle seismic anisotropy from SKS splitting in the South American stable platform: a test of asthenospheric flow models beneath the lithosphere. Lithosphere 3, 173-180.

Auer, L., Boschi, L., Becker, T., Nissen-Meyer, T., Giardini, D., 2014. Savani: a variable resolution whole-mantle model of anisotropic shear velocity variations based on multiple data sets. J. Geophys. Res. 119, 3006-3034.

Aulbach, S., 2012. Craton nucleation and formation of thick lithospheric roots. Lithos 149, $16-30$.

Austin, N.J., Evans, B., 2007. Paleowattmeters: a scaling relation for dynamically recrystallized grain size. Geology 35, 343-346.

Babuska, V., Plomerova, J., Sileny, J., 1984. Large scale oriented structures in the subcrustal lithosphere of Central Europe. Ann. Geophys. Gauthier-Villars, pp. 649-662.

Bagley, B., Nyblade, A.A., 2013. Seismic anisotropy in eastern Africa, mantle flow, and the African superplume. Geophys. Res. Lett. 40, 1500-1505.

Bai, Q., Mackwell, S.J., Kohlstedt, D.L., 1991. High-temperature creep of olivine single crystals. 1. Mechanical results for buffered samples. J. Geophys. Res. 96, 2441-2463.

Bamford, D., 1977. Pn velocity anisotropy in a continental upper mantle. Geophys. J. R. Astron. Soc. 47, 397-529.

Baptiste, V., Tommasi, A., 2014. Petrophysical constraints on the seismic properties of the Kaapvaal mantle root. Solid Earth 5, 1-19. http://dx.doi.org/10.5194/se-5195-51912014.

Baptiste, V., Tommasi, A., Demouchy, S., 2012. Deformation and hydration of the lithospheric mantle beneath the Kaapvaal craton, South Africa. Lithos 149, 31-50.

Baptiste, V., Vauchez, A., Tommasi, A., Demouchy, S., Rudnick, R., 2015. Deformation, hydration, and anisotropy of the lithospheric mantle beneath an active rift: constraints from mantle xenoliths from the North Tanzanian Divergence. Tectonophysics 639, 34-55.

Bascou, J., Delpech, G., Vauchez, A., Moine, B.N., Cottin, J.Y., Barruol, G., 2008. An integrated study of microstructural, geochemical, and seismic properties of the lithospheric mantle above the Kerguelen plume (Indian Ocean). Geochem. Geophys. Geosyst. 9, Q04036.

Bascou, J., Doucet, L.S., Saumet, S., Ionov, D.A., Ashchepkov, I.V., Golovin, A.V., 2011. Seismic velocities, anisotropy and deformation in Siberian cratonic mantle: EBSD data on xenoliths from the Udachnaya kimberlite. Earth Planet. Sci. Lett. 304, 71-84.

Bastow, I., Nyblade, A., Stuart, G., Rooney, T., Benoit, M., 2008. Upper mantle seismic structure beneath the Ethiopian hot spot: rifting at the edge of the African low-velocity anomaly. Geochem. Geophys. Geosyst. 9, Q12022.

Basu, A.R., 1977. Textures, microstructures and deformation of ultramafic xenoliths from San Quintin, Baja California. Tectonophysics 43, 213-245.

Beauchamp, W., Barazangi, M., Demnati, A., El Alji, M., 1996. Intracontinental rifting and inversion: Missour basin and Atlas mountains, Morocco. AAPG Bull. 80, 1459-1481.

Becker, T., Lebedev, S., Long, M., 2012. On the relationship between azimuthal anisotropy from shear wave splitting and surface wave tomography. J. Geophys. Res. 117, B01306.

Bedini, R.M., Bodinier, J.-L., Dautria, J.-M., Morten, L., 1997. Evolution of LILE-enriched small melt fractions in the lithospheric mantle: a case study from the East African rift. Earth Planet. Sci. Lett. 153, 67-83.

Behr, W.M., Hirth, G., 2014. Rheological properties of the mantle lid beneath the Mojave region in southern California. Earth Planet. Sci. Lett. 393, 60-72.

Ben Ismail, W., Mainprice, D., 1998. An olivine fabric database: an overview of upper mantle fabrics and seismic anisotropy. Tectonophysics 296, 145-158.

Bercovici, D., Ricard, Y., 2012. Mechanisms for the generation of plate tectonics by twophase grain-damage and pinning. Phys. Earth Planet. Inter. 202, 27-55.

Bercovici, D., Ricard, Y., 2014. Plate tectonics, damage and inheritance. Nature 508, 513-516.

Berger, E.T., Vannier, M., 1984. Les dunites en enclaves dans les basaltes alcalins des îles océaniques: approche pétrologique. Bull. Mineral. 107, 649-663.

Bezacier, L., Reynard, B., Bass, J.D., Sanchez-Valle, C., Van de Moortèle, B., 2010. Elasticity of antigorite, seismic detection of serpentinites, and anisotropy in subduction zones. Earth Planet. Sci. Lett. 289, 198-208.

Bielinski, R.A., Park, S.K., Rybin, A., Batalev, V., Jun, S., Sears, C., 2003. Lithospheric heterogeneity in the Kyrgyz Tien Shan imaged by magnetotelluric studies. Geophys. Res. Lett. 30, 1806. http://dx.doi.org/10.1029/2003GL017455. 
Blackman, D.K., Kendall, J.-M., 1997. Sensitivity of teleseismic body waves to mineral texture and melt in the mantle beneath a mid-ocean ridge. Philos. Trans. R. Soc. Lond. A355, 217-231.

Bodinier, J., 1988. Geochemistry and petrogenesis of the Lanzo peridotite body, western Alps. Tectonophysics 149, 67-88.

Bodinier, J.L., Godard, M., 2007. Orogenic, ophiolitic, and abyssal peridotites. In: Turekian, K., Holland, H. (Eds.), Treatise on Geochemistry. The Mantle and Core vol. 2, pp. 1-73. http://dx.doi.org/10.1016/B0-08-043751-6/02004-1.

Bodinier, J., Guiraud, M., Fabries, J., Dostal, J., Dupuy, C., 1987. Petrogenesis of layered pyroxenites from the Lherz, Freychinede and Prades ultramafic bodies (Ariege, French Pyrenees). Geochim. Cosmochim. Acta 51, 279-290.

Bodinier, J.L., Vasseur, G., Vernieres, J., Dupuy, C., Fabries, J., 1990. Mechanisms of mantle metasomatism; geochemical evidence from the Lherz orogenic peridotite. J. Petrol. 31, 597-628.

Bonnin, M., Barruol, G., Bokelmann, G.H., 2010. Upper mantle deformation beneath the North American-Pacific plate boundary in California from SKS splitting. J. Geophys. Res. 115, B04306. http://dx.doi.org/10.1029/2009JB006438.

Bostock, M.E., 1997. Anisotropic upper-mantle stratigraphy and architecture of the Slave Craton. Nature 390, 392-395.

Bostock, M., 1998. Mantle stratigraphy and evolution of the Slave province. J. Geophys. Res. 103, 21183-21200.

Bosworth, W., Strecker, M.R., 1997. Stress field changes in the Afro-Arabian rift system during the Miocene to Recent period. Tectonophysics 278, 47-62.

Boudier, F., 1978. Structure and petrology of the Lanzo massif (Piedmont Alps). Geol. Soc. Am. Bull. 89, 1574-1591.

Boudier, F., Coleman, R.G., 1981. Cross section through the peridotites in the Samail ophiolite, southeastern Oman. J. Geophys. Res. 86, 2573-2592.

Boudier, F., Nicolas, A., 1985. Harzburgite and lherzolite subtypes in ophiolitic and oceanic environments. Earth Planet. Sci. Lett. 76, 84-92.

Boudier, F., Nicolas, A., 1995. Nature of the Moho transition zone in the Oman ophiolite. J. Petrol. 36, 777-796.

Boudier, F., Ceuleneer, G., Nicolas, A., 1988. Shear zones, thrusts and related magmatism in the Oman ophiolite: initiation of thrusting on an oceanic ridge. Tectonophysics 151 275-296.

Boudier, F., Baronnet, A., Mainprice, D., 2010. Serpentine mineral replacements of natural olivine and their seismic implications: oceanic lizardite versus subduction-related antigorite. J. Petrol. 51, 495-512.

Boullier, A.M., Gueguen, Y., 1975. S-P mylonites. Origin of some mylonites by superplastic flow. Contrib. Mineral. Petrol. 50, 121-134.

Boullier, A.M., Nicolas, A., 1973. Fabric analysis of the ultrabasic nodules from Thaba Putsoa and Mothae. Kimberlites of the Nothern Lesotho Province. Cape and Transvaal Printers Ltd., pp. 57-66.

Boyd, F.R., Gurney, J.J., 1986. Diamonds and the African lithosphere. Science 232, 472-477.

Boyd, F.R., Pokhilenko, N.P., Pearson, D.G., Mertzman, S.A., Sobolev, N.V., Finger, L.W. 1997. Composition of the Siberian cratonic mantle: evidence from Udachnaya peridotite xenoliths. Contrib. Mineral. Petrol. 128, 228-246.

Bradley, R., Jamil, A., Munro, D., 1964. The electrical conductivity of olivine at high temperatures and pressures. Geochim. Cosmochim. Acta 28, 1669-1678.

Braun, M.G., Kelemen, P.B., 2002. Dunite distribution in the Oman Ophiolite: implications for melt flux through porous dunite conduits. Geochem. Geophys. Geosyst. 3, 1-21. http://dx.doi.org/10.1029/2001GC000289.

Braun, J., Chéry, J., Poliakov, A., Mainprice, D., Vauchez, A., Tommasi, A., Daignières, M., 1999. A simple parameterization of strain localization in the ductile regime. J. Geophys. Res. 104 (25,167-25,182).

Buehler, J., Shearer, P., 2014. Anisotropy and Vp/Vs in the uppermost mantle beneath the western United States from joint analysis of Pn and Sn phases. J. Geophys. Res. 119, 1200-1219.

Buiskol Toxopeus, J.M.A., 1977. Fabric development of olivine in a peridotite mylonite. Tectonophysics 39, 55-71.

Buontempo, L., Bokelmann, G., Barruol, G., Morales, J., 2008. Seismic anisotropy beneath southern Iberia from SKS splitting. Earth Planet. Sci. Lett. 273, 237-250.

Bystricky, M., Kunze, K., Burlini, L., Burg, J.P., 2000. High shear strain of olivine aggregates: rheological and seismic consequences. Science 290, 1564-1567.

Cabanes, N., Briqueu, L., 1987. Hydration of an active shear zone: interaction between deformation, metasomatism and metamorphism - the spinellherzolites from the Montferrier (Southern France) Oligocene basalts. Earth Planet. Sci. Lett. 81, 233-244.

Cabanes, N., Mercier, J.-C., 1988. Insight into the upper mantle beneath an active extensional zone: the spinel-peridotite xenoliths from San Quintin (Baja California, Mexico). Contrib. Mineral. Petrol. 100, 374-382.

Calvert, A., Sandvol, E., Seber, D., Barazangi, M., Vidal, F., Alguacil, G., Jabour, N., 2000. Propagation of regional seismic phases ( $\mathrm{Lg}$ and $\mathrm{Sn}$ ) and Pn velocity structure along the Africa-Iberia plate boundary zone: tectonic implications. Geophys. J. Int. 142, 384-408.

Chai, M., Brown, J.M., Slutsky, L.J., 1996. Thermal diffusivity of mantle minerals. Phys. Chem. Miner. 23, 470-475.

Chen, C., Zhao, D., Wu, S., 2014. Crust and upper mantle structure of the New Madrid Seismic Zone: insight into intraplate earthquakes. Phys. Earth Planet. Inter. 230, 1-14.

Chesley, J.T., Rudnick, R.L., Lee, C.-T., 1999. Re-Os systematics of mantle xenoliths from the East African Rift: age, structure, and history of the Tanzanian craton. Geochim. Cosmochim. Acta 63, 1203-1217.

Chopra, P.N., Paterson, M.S., 1984. The role of water in the deformation of dunite. J. Geophys. Res. 86, 7861-7876.

Chorowicz, J., 2005. The East African rift system. J. Afr. Earth Sci. 43, 379-410.

Christensen, N.I., 2004. Serpentinites, peridotites, and seismology. International Book Series 8 pp. $503-524$
Constable, S., Shankland, T.J., Duba, A., 1992. The electrical conductivity of an isotropic olivine mantle. J. Geophys. Res. 97, 3397-3404.

Courtillot, V., Jaupart, C., Manighetti, I., Tapponnier, P., Besse, J., 1999. On causal links between flood basalts and continental breakup. Earth Planet. Sci. Lett. 166, 177-195.

Crampin, S., Chesnokov, E.M., Hipkins, R.G., 1984. Seismic anisotropy - the state of art: II Geophys. J. R. Astron. Soc. 76, 1-16.

Dabrowski, M., Schmid, D.W., Podladchikov, Y.Y., 2012. A two-phase composite in simple shear: effective mechanical anisotropy development and localization potential. J. Geophys. Res. 117, B08406. http://dx.doi.org/10.1029/2012JB009183.

Dai, L., Karato, S.I., 2014. High and highly anisotropic electrical conductivity of the asthenosphere due to hydrogen diffusion in olivine. Earth Planet. Sci. Lett. 408, 79-86.

Davaille, A., Jaupart, C., 1993. Transient high Rayleigh number thermal convection with large viscosity variations. J. Fluid Mech. 253, 141-166.

Davies, J.H., 2013. Global map of solid earth surface heat flow. Geochem. Geophys. Geosyst. 14, 4608-4622.

Dawson, J.B., Smith, J.V., 1977. The MARID (mica-amphibole-rutile-ilmenite-diopside) suite of xenoliths in kimberlite. Geochim. Cosmochim. Acta 41, 309-323.

De Bresser, J., Ter Heege, J., Spiers, C., 2001. Grain size reduction by dynamic recrystallization: can it result in major rheological weakening? Int. J. Earth Sci. 90, 28-45.

Debayle, E., Kennett, B., 2000. Anisotropy in the Australasian upper mantle from Love and Rayleigh waveform inversion. Earth Planet. Sci. Lett. 184, 339-351.

Debayle, E., Ricard, Y., 2012. A global shear velocity model of the upper mantle from fundamental and higher Rayleigh mode measurements. J. Geophys. Res. 117, B10308.

Debayle, E., Ricard, Y., 2013. Seismic observations of large-scale deformation at the bottom of fast-moving plates. Earth Planet. Sci. Lett. 376, 165-177.

Demouchy, S., Tommasi, A., Barou, F., Mainprice, D., Cordier, P., 2012. Deformation of olivine in torsion under hydrous conditions. Phys. Earth Planet. Inter. 202, 56-70.

Demouchy, S., Tommasi, A., Boffa Ballaran, T., Cordier, P., 2013. Low strength of Earth's uppermost mantle inferred from tri-axial deformation experiments on dry olivine crystals. Phys. Earth Planet. Inter. 220, 37-49.

Demouchy, S., Mussi, A., Barou, F., Tommasi, A., Cordier, P., 2014. Viscoplasticity of polycrystalline olivine experimentally deformed at high pressure and $900{ }^{\circ} \mathrm{C}$. Tectonophysics 623, 123-135.

Demouchy, S., Ishikawa, A., Tommasi, A., Alard, O., Keshav, S., 2015. Characterization of hydration in the lithospheric mantle: peridotite xenoliths from the Ontong Java Plateau as an example. Lithos 212, 189-201.

Deschamps, F., Lebedev, S., Meier, T., Trampert, J., 2008. Stratified seismic anisotropy reveals past and present deformation beneath the East-central United States. Earth Planet. Sci. Lett. 274, 489-498.

Diaz, J., Gallart, J., Villaseñor, A., Mancilla, F., Pazos, A., Córdoba, D., Pulgar, J., Ibarra, P. Harnafi, M., 2010. Mantle dynamics beneath the Gibraltar Arc (western Mediterranean) from shear-wave splitting measurements on a dense seismic array. Geophys. Res. Lett. 37, L18304. http://dx.doi.org/10.1029/2010GL044201.

Dijkstra, A.H., Drury, M.R., Vissers, R.L., 2001. Structural petrology of plagioclase peridotites in the West Othris Mountains (Greece): melt impregnation in lithospheric mantle. J. Petrol. 42, 5-24.

Dijkstra, A.H., Drury, M.R., Frijhoff, R.M., 2002. Microstructures and lattice fabrics in the Hilti mantle section (Oman Ophiolite): evidence for shear localization and melt weakening in the crust-mantle transition zone? J. Geophys. Res. 107 (ETG 2-1-ETG 2-18).

Dijkstra, A.H., Barth, M.G., Drury, M.R., Mason, P.R.D., Vissers, R.L.M., 2003. Diffuse porous melt flow and melt-rock reaction in the lithospheric mantle at a slow-spreading ridge: a structural petrology and LA-ICP-MS study of the Othris Peridotite Massif (Greece). Geochem. Geophys. Geosyst. 4, 1-24.

Dijkstra, A.H., Drury, M.R., Vissers, R.L., Newman, J., Van Roermund, H.L., 2004. Shear zones in the upper mantle: evidence from alpine- and ophiolite-type peridotite massifs. Geol. Soc. Lond., Spec. Publ. 224, 11-24.

Doin, M.-P., Fleitout, L., McKenzie, D., 1996. Geoid anomalies and the structure of continental and oceanic lithospheres. J. Geophys. Res. 101 (16,119-116,135).

Doin, M.-P., Fleitout, L., Christensen, U., 1997. Mantle convection and stability of depleted and undepleted continental lithosphere. J. Geophys. Res. 102, 2771-2787.

Dong, H., Wei, W., Ye, G., Jin, S., Jones, A.G., Jing, J., Zhang, L., Xie, C., Zhang, F., Wang, H., 2014. Three dimensional electrical structure of the crust and upper mantle in Ordos block and adjacent area: evidence of regional lithospheric modification. Geochem. Geophys. Geosyst. 15, 2414-2425.

Doucet, L.S., Peslier, A.H., Ionov, D.A., Brandon, A.D., Golovin, A.V., Goncharov, A.G. Ashchepkov, I.V., 2014. High water contents in the Siberian cratonic mantle linked to metasomatism: an FTIR study of Udachnaya peridotite xenoliths. Geochim. Cosmochim. Acta 137, 159-187.

Downes, H., Macdonald, R., Upton, B.G. Cox, K.G., Bodinier, J.-L, Mason, P.R., James, D., Hill, P.G., Hearn, B.C., 2004. Ultramafic xenoliths from the Bearpaw Mountains, Montana, USA: evidence for multiple metasomatic events in the lithospheric mantle beneath the Wyoming craton. J. Petrol. 45, 1631-1662.

Drury, M.R., Vissers, R.L.M., Van der Wal, D., Strating, E.H.H., 1991. Shear localisation in upper mantle peridotites. Pure Appl. Geophys. 137, 439-460.

Duba, A., Heard, H., Schock, R., 1974. Electrical conductivity of olivine at high pressure and under controlled oxygen fugacity. J. Geophys. Res. 79, 1667-1673.

Ducea, M.N., Park, S.K., 2000. Enhanced mantle conductivity from sulfide miinerals, southern Sierra Nevada, California. Geophys. Res. Lett. 27, 2405-2408.

Dunbar, J.A., Sawyer, D.S., 1988. Continental rifting at pre-existing lithospheric weaknesses. Nature 333, 450-452.

Durham, W.B., Goetze, G., 1977. Plastic flow of oriented single crystals of olivine. 1 Mechanical data. J. Geophys. Res. 82, 5737-5753.

Eaton, D.W., Jones, A.G., Fergunson, I.J., 2004. Lithospheric anisotropy structure inferred form collocated teleseismic and magnetotelluric observations: Great Slave Lake 
shear zone, northern Canada. Geophys. Res. Lett. 31, L19614. http://dx.doi.org/10. 1029/2004GL020939.

El Messbahi, H., Bodinier, J.-L., Vauchez, A., Dautria, J.-M., Ouali, H., Garrido, C.J., 2015 Short wavelength lateral variability of lithospheric mantle beneath the Middle Atlas (Morocco) as recorded by mantle xenoliths. Tectonophysics 650, 34-52. http://dx.doi.org/10.1016/j.tecto.2014.1011.1020.

Endrun, B., Lebedev, S., Meier, T., Tirel, C., Friederich, W., 2011. Complex layered deformation within the Aegean crust and mantle revealed by seismic anisotropy. Nat. Geosci. 4, 203-207.

England, P., Houseman, G., 1985. Role of lithospheric strength heterogeneities in the tectonics of Tibet and neighbouring regions. Nature 315, 297-301.

Evans, B., Renner, J., Hirth, G., 2001. A few remarks on the kinetics of static grain growth in rocks. Int. J. Earth Sci. 90, 88-103.

Evans, R.L., Jones, A.G., Garcia, X., Muller, M., Hamilton, M., Evans, S., Fourie, C., Spratt, J., Webb, S., Jelsma, H., 2011. Electrical lithosphere beneath the Kaapvaal craton, southern Africa. J. Geophys. Res. 116, B04105. http://dx.doi.org/10.1029/2010JB007883.

Falus, G., Tommasi, A., Ingrin, J., Csaba, S., 2008. Deformation and seismic anisotropy of the lithospheric mantle in the southeastern Carpathians as inferred from the study of mantle xenoliths. Earth Planet. Sci. Lett. 272, 50-64. http://dx.doi.org/10.1016/j.epsl. 2008.1004.1035.

Falus, G., Tommasi, A., Soustelle, V., 2011. The effect of dynamic recrystallization on olivine crystal preferred orientations in mantle xenoliths deformed under varied stress conditions. J. Struct. Geol. 33, 1528-1540.

Farra, V., Vinnik, L., 2000. Upper mantle stratification by P and S receiver functions. Geophys. J. Int. 141, 699-712.

Fei, H., Wiedenbeck, M., Yamazaki, D., Katsura, T., 2013. Small effect of water on uppermantle rheology based on silicon self-diffusion coefficients. Nature 498, 213-215.

Fishwick, S., Kennett, B., Reading, A., 2005. Contrasts in lithospheric structure within the Australian craton-insights from surface wave tomography. Earth Planet. Sci. Lett. $231,163-176$

Foley, S.F., 2008. Rejuvenation and erosion of the cratonic lithosphere. Nat. Geosci. 1, 503-510.

Ford, H.A., Fischer, K.M., Abt, D.L., Rychert, C.A., Elkins-Tanton, L.T., 2010. The lithosphereasthenosphere boundary and cratonic lithospheric layering beneath Australia from Sp wave imaging. Earth Planet. Sci. Lett. 300, 299-310.

Forsyth, D.W., 1975. The early structural evolution and anisotropy of the oceanic mantle. Geophys. J. R. Astron. Soc. 43, 103-162.

Fouch, M.J., James, D.E., VanDecar, J.C., van der Lee, S., 2004. Mantle seismic structure beneath the Kaapvaal and Zimbabwe Cratons. Afr. J. Geol. 107, 33-44.

Fournier, M., Chamot-Rooke, N., Petit, C., Huchon, P., Al-Kathiri, A., Audin, L., Beslier, M.O., d'Acremont, E., Fabbri, O., Fleury, J.M., 2010. Arabia-Somalia plate kinematics, evolution of the Aden-Owen-Carlsberg triple junction, and opening of the Gulf of Aden. J. Geophys. Res. 115, B04102. http://dx.doi.org/10.1029/ 2008JB006257.

Frese, K., Trommsdorff, V., Kunze, K., 2003. Olivine [100] normal to foliation: lattice preferred orientation in prograde garnet peridotite formed at high $\mathrm{H} 2 \mathrm{O}$ activity, Cima di Gagnone (Central Alps). Contrib. Mineral. Petrol. 145, 75-86.

Frets, E., Tommasi, A., Garrido, C.J., Padrón-Navarta, J.A., Amri, I., Targuisti, K., 2012. Deformation processes and rheology of pyroxenites under lithospheric mantle conditions. J. Struct. Geol. 39, 138-157.

Frets, E.C., Tommasi, A., Garrido, C.J., Vauchez, A., Mainprice, D., Targuisti, K., Amri, I., 2014 The Beni Bousera Peridotite (Rif Belt, Morocco): an oblique-slip low-angle shear zone thinning the subcontinental lithospheric mantle. J. Petrol. 55, 283-313.

Fuchs, K., 1977. Seismic anisotropy of the subcrustal lithosphere as evidence for dynamical processes in the upper mantle. Geophys. J. R. Astron. Soc. 49, 167-179.

Furumura, T., Kennett, B., 2005. Subduction zone guided waves and the heterogeneity structure of the subducted plate: intensity anomalies in northern Japan. J. Geophys. Res. 110, B10302. http://dx.doi.org/10.1029/2004JB003486.

Furusho, M., Kanagawa, K., 1999. Transformation induced strain localization in a lherzolite mylonite from the Hidaka metamorphic belt of central Hokkaido, Japan. Tectonophysics 313, 411-432.

Garrido, C.J., Bodinier, J.-L., 1999. Diversity of mafic rocks in the Ronda peridotite: evidence for pervasive melt-rock reaction during heating of subcontinental lithosphere by upwelling asthenosphere. J. Petrol. 40, 729-754.

Garrido, C.J., Gueydan, F., Booth-Rea, G., Precigout, J., Hidas, K., Padrón-Navarta, J.A Marchesi, C., 2011. Garnet lherzolite and garnet-spinel mylonite in the Ronda peridotite: vestiges of Oligocene backarc mantle lithospheric extension in the western Mediterranean Geology 39, 927-930.

Gatzemeier, A., Moorkamp, M., 2005. 3D modelling of electrical anisotropy from electromagnetic array data: hypothesis testing for different upper mantle conduction mechanisms. Phys. Earth Planet. Inter. 149, 225-242.

Gatzemeier, A., Tommasi, A., 2006. Flow and electrical anisotropy in the upper mantle: finite-element models constraints on the effects of olivine crystal preferred orientation and microstructure. Phys. Earth Planet. Inter. 158, 92-106.

Geoffroy, L., Bergerat, F., Angelier, J., 1994. Tectonic evolution of the Greenland-Scotland Ridge during the Paleogene; new constraints. Geology 22, 653-656.

Gibert, B., Seipold, U., Tommasi, A., Mainprice, D., 2003. Upper mantle thermal diffusivity: pressure- and temperature dependences and anisotropy. J. Geophys. Res. 108, 2359. http://dx.doi.org/10.1029/2002JB002108.

Gibert, B., Schilling, F.R., Gratz, K., Tommasi, A., 2005. Radiative heat transfer in olivine crystals and upper mantle rocks. Phys. Earth Planet. Inter. 151, 129-141.

Girard, J., Chen, J., Raterron, P., Holyoke, C.W., 2013. Hydrolytic weakening of olivine at mantle pressure: evidence of [100](010) slip system softening from single-crystal deformation experiments. Phys. Earth Planet. Inter. 216, 12-20.

Goetze, C., 1975. Sheared iherzolites: from the point of view of rock mechanics. Geology 3 , $172-173$.
Griffin, W., Andi, Z., O'reilly, S., Ryan, C., 1998. Phanerozoic evolution of the lithosphere beneath the Sino-Korean craton. In: Flower, M.F.J., Chung, S.-L., Lo, C.-H., Lee, T.-Y. (Eds.), Mantle Dynamics and Plate Interactions in East Asia. American Geophysical Union, Washington, D. C., pp. 107-126 http://dx.doi.org/10.1029/GD027p0107107-126.

Guillope, M., Poirier, J., 1979. Dynamic recrystallization during creep of single-crystalline halite: an experimental study. J. Geophys. Res. 84, 5557-5567.

Gung, Y., Panning, M., Romanowicz, B., 2003. Global anisotropy and the thickness of continents. Nature 422, 707-711.

Hamilton, M.P., Jones, A.G., Evans, R.L., Evans, S., Fourie, C.J.S., Garcia, X., Mountford, A., Spratt, J.E., Team, S.M., 2006. Electrical anisotropy of South African lithosphere compared with seismic anisotropy from shear-wave splitting analyses. Phys. Earth Planet. Inter. 158, 226-239.

Hammond, J., Kendall, J.M., Wookey, J., Stuart, G., Keir, D., Ayele, A., 2014. Differentiating flow, melt, or fossil seismic anisotropy beneath Ethiopia. Geochem. Geophys. Geosyst. $15,1878-1894$

Hanmer, S., Bowring, S., van Breemen, O., Parrish, R., 1992. Great Slave Lake shear zone, NW Canada: mylonitic record of Early Proterozoic continental convergence, collision and indentation. J. Struct. Geol. 14, 757-773.

Hansen, L., Zimmerman, M., Kohlstedt, D., 2012. Laboratory measurements of the viscous anisotropy of olivine aggregates. Nature 492, 415-418.

Hansen, L.N., Zhao, Y.H., Zimmerman, M.E., Kohlstedt, D.L., 2014. Protracted fabric evolution in olivine: implications for the relationship among strain, crystallographic fabric, and seismic anisotropy. Earth Planet. Sci. Lett. 387, 157-168.

Hearn, T.M., 1996. Anisotropic Pn tomography in the western United States. J. Geophys. Res. 101, 8403-8414.

Heintz, M., Vauchez, A., Assumpção, M., Barruol, G., Egydio-Silva, M., 2003. Shear wave splitting in SE Brazil: an effect of active or fossil upper mantle flow, or both? Earth Planet. Sci. Lett. 211, 79-95.

Herwegh, M. Linckens, J., Ebert, A., Berger, A., Brodhag S., 2011. The role of second phases for controlling microstructural evolution in polymineralic rocks: a review. J. Struct. Geol. 33, 1728-1750.

Hess, H.H., 1964. Seismic anisotropy of the uppermost mantle under oceans. Nature 203, 629-631.

Hidas, K., Garrido, C.J., Tommasi, A., Padrón-Navarta, J.A., Thielmann, M., Konc, Z., Frets, E., Marchesi, C., 2013. Strain localization in pyroxenite by reaction-enhanced softening in the shallow subcontinental lithospheric mantle. J. Petrol. 54, 1997-2031.

Hidas, K., Tommasi, A., Garrido, C.J., Padron-Navarta, J.A., Mainprice, D., Vauchez, A., Marchesi, C., F.B., 2015. Fluid-assisted strain localization in the shallow lithospheric mantle. Earth Planet. Sci. Lett. (submitted for publication).

Hielscher, R., Schaeben, H., 2008. A novel pole figure inversion method: specification of the MTEX algorithm. J. Appl. Crystallogr. 41, 1024-1037.

Higgie, K., Tommasi, A., 2012. Feedbacks between deformation and melt distribution in the crust-mantle transition zone of the Oman ophiolite. Earth Planet. Sci. Lett. 359, 61-72.

Higgie, K., Tommasi, A., 2014. Deformation in a partially molten mantle: constraints from plagioclase-lherzolites from Lanzo, western Alps. Tectonophysics 615-616, 167-181.

Hiraga, T., Tachibana, C., Ohashi, N., Sano, S., 2010. Grain growth systematics for forsterite \pm enstatite aggregates: effect of lithology on grain size in the upper mantle. Earth Planet. Sci. Lett. 291, 10-20.

Hiraga, T., Miyazaki, T., Yoshida, H., Zimmerman, M.E., 2013. Comparison of microstructures in superplastically deformed synthetic materials and natural mylonites: mineral aggregation via grain boundary sliding. Geology 41, 959-962.

Hirn, A., 1977. Anisotropy in the continental upper mantle: possible evidence from explosion seismology. Geophys. J. R. Astron. Soc. 49, 49-58.

Hirth, G., Kohlstedt, D., 2003. Rheology of the upper mantle and the mantle wedge: a view from the experimentalists. Inside the Subduction Factorypp. 83-105.

Hoffman, P.F., 1987. Continental transform tectonics: Great Slave Lake shear zone (ca. 1.9 Ga), northwest Canada. Geology 15, 785-788.

Holtzman, B.K., Kendall, J., 2010. Organized melt, seismic anisotropy, and plate boundary lubrication. Geochem. Geophys. Geosyst. 11, Q0AB06. http://dx.doi.org/10.1029/ 2010GC003296.

Holtzman, B.K., Kohlstedt, D.L., Zimmerman, M.E., Heidelbach, F., Hiraga, T., Hustoft, J., 2003. Melt segregation and strain partitioning; implications for seismic anisotropy and mantle flow. Science 301, 1227-1230.

Holtzman, B.K., King, D.S., Kohlstedt, D.L., 2012. Effects of stress-driven melt segregation on the viscosity of rocks. Earth Planet. Sci. Lett. 359, 184-193.

Homuth, B., Rümpker, G., Deckert, H., Kracht, M., 2014. Seismicity of the northern Upper Rhine Graben-constraints on the present-day stress field from focal mechanisms. Tectonophysics 632, 8-20.

Huang, Z., Zhao, D., 2013. Mapping P-wave azimuthal anisotropy in the crust and upper mantle beneath the United States. Phys. Earth Planet. Inter. 225, 28-40.

Jackson, I., FitzGerald, J.D., Faul, U.H., Tan, B.H., 2002. Grain-size sensitive seismic wave attenuation in polycrystalline olivine. J. Geophys. Res. 107. http://dx.doi.org/10.1029/ 2001JB001225 (2360-2075).

Jacob, J., Dyment, J., 2014. Early opening of Australia and Antarctica: new inferences and regional consequences. Tectonophysics 636, 244-256.

James, D., Fouch, M., VanDecar, J., van der Lee, S., 2001. Tectospheric structure beneath southern Africa. Geophys. Res. Lett. 28, 2485-2488.

James, D.E., Boyd, F.R., Schutt, D., Bell, D.R., Carlson, R.W., 2004. Xenolith constraints on seismic velocities in the upper mantle beneath southern Africa. Geochem. Geophys. Geosyst. 5, Q01002. http://dx.doi.org/10.1029/2003GC000551.

Jaroslow, G.E., Hirth, G., Dick, H.J.B., 1996. Abyssal peridotite mylonites: implications for grain-size sensitive flow and strain localization in the oceanic lithosphere. Tectonophysics 256, 17-37.

Ji, S., Rondenay, S., Mareschal, M., Senechal, G., 1996. Obliquity between seismic and electrical anisotropies as a potential indicator of movement sense for ductile shear zones in the upper mantle. Geology 24, 1033-1036. 
Ji, S., Wang, Z., Wirth, R., 2001. Bulk flow strength of forsterite-enstatite composites as a function of forsterite content. Tectonophysics 341, 69-93.

Jones, A.G., 1999. Imaging the continental upper mantle using electromagnetic methods. Dev. Geotectonics 24, 57-80.

Jones, A.G., Ferguson, I.J., Chave, A.D., Evans, R.L., McNeice, G.W., 2001. Electric lithosphere of the Slave craton. Geology 29, 423-426.

Jones, A.G., Snyder, D., Hanmer, S., Asudeh, I., White, D., Eaton, D., Clarke, G., 2002. Magnetotelluric and teleseismic study across the Snowbird Tectonic Zone, Canadian Shield: a Neoarchean mantle suture? Geophys. Res. Lett. 29, 1829. http://dx.doi.org/ 10.1029/2002GL015359.

Jordan, T.H., 1975. The continental tectosphere. Rev. Geophys. Space Phys. 13, 1-12.

Jordan, T.H., 1979. Mineralogies, densities and seismic velocities of garnet lherzolites and their geophysical implications. In: Boyd, F.R., Meyer, H.O.A. (Eds.), The Mantle Sample: Inclusion in Kimberlites and Other Volcanics. American Geophysical Union, Washington, D.C., pp. 1-14.

Jousselin, D., Morales, L.F.G., Nicolle, M., Stephant, A., 2012. Gabbro layering induced by simple shear in the Oman ophiolite Moho transition zone. Earth Planet. Sci. Lett. 331-332, 55-66

Judenherc, S., Granet, M., Brun, J.-P., Poupinet, G., 2003. The Hercynian collision in the Armorican Massif; evidence of different lithospheric domains inferred from seismic tomography and anisotropy. Bull. Soc. Geol. Fr. 174, 45-57.

Jung, H., Lee, J., Ko, B., Jung, S., Park, M., Cao, Y., Song, S., 2013. Natural type-C olivine fabrics in garnet peridotites in North Qaidam UHP collision belt, NW China. Tectonophysics 594, 91-102.

Kaczmarek, M.-A., Müntener, O., 2008. Juxtaposition of melt impregnation and hightemperature shear zones in the upper mantle; field and petrological constraints from the Lanzo Peridotite (Northern Italy). J. Petrol. 49, 2187-2220.

Kaczmarek, M.-A., Tommasi, A., 2011. Anatomy of an extensional shear zone in the mantle (Lanzo massif, Italy). Geochem. Geophys. Geosyst. 12, Q0AG06. http://dx.doi.org/ 10.1029/2011GC003627.

Kaeser, B., Kalt, A., Pettke, T., 2006. Evolution of the lithospheric mantle beneath the Marsabit volcanic field (northern Kenya): constraints from textural, P-T and geochemical studies on xenoliths. J. Petrol. 47, 2149-2184.

Kameyama, M., Yuen, D.A., Fujimoto, H., 1997. The interaction of viscous heating with grain-size dependent rheology in the formation of localized slip zones. Geophys. Res. Lett. 24, 2523-2526.

Karato, S., 1989. Grain growth kinetics in olivine aggregates. Tectonophysics 168, 255-273.

Karato, S.-I., Paterson, M.S., Fitzgerald, J.D., 1986. Rheology of synthetic olivine aggregates: influence of water and grain size. J. Geophys. Res. 91, 8151-8176.

Karato, S.I., Jung, H., Katayama, I., Skemer, P., 2008. Geodynamic significance of seismic anisotropy of the upper mantle: new insights from laboratory studies. Annu. Rev. Earth Planet. Sci. 36, 59-95.

Kawakatsu, H., Kumar, P., Takei, Y., Shinohara, M., Kanazawa, T., Araki, E., Suyehiro, K., 2009. Seismic evidence for sharp lithosphere-asthenosphere boundaries of oceanic plates. Science $324,499-502$.

Kaya, T., Kasaya, T., Tank, S.B., Ogawa, Y., Tunçer, M.K., Oshiman, N., Honkura, Y., Matsushima, M., 2013. Electrical characterization of the North Anatolian Fault Zone underneath the Marmara Sea, Turkey by ocean bottom magnetotellurics. Geophys. J. Int. 193, 664-677.

Kelemen, P.B., Dick, H.J.B., 1995. Focused melt flow and localized deformation in the upper mantle; juxtaposition of replacive dunite and ductile shear zones in the Josephine Peridotite, SW Oregon. J. Geophys. Res. 100, 423-438.

Kelemen, P.B., Joyce, D.B., Webster, J.D., Holloway, J.R., 1990. Reaction between ultramafic rock and fractionating basaltic magma; II, experimental investigation of reaction between olivine tholeiite and harzburgite at $1150-1050{ }^{\circ} \mathrm{C}$ and $5 \mathrm{~kb}$. J. Petrol. 31, 99-134.

Kelemen, P.B., Whitehead, J., Aharonov, E., Jordahl, K.A., 1995. Experiments on flow focusing in soluble porous media, with applications to melt extraction from the mantle. J. Geophys. Res. 100, 475-496.

Keppie, J.D., 1989. Northern Appalachian terranes and their accretionary history. In: Dallmeyer, R.D. (Ed.), Terranes in the Circum-Atlantic Paleozoic orogens, pp. 159-192.

Kern, H., Liu, B., Popp, T., 1997. Relationship between anisotropy of $\mathrm{P}$ and $\mathrm{S}$ wave velocities and anisotropy of attenuation in serpentinite and amphibolite. J. Geophys. Res. 102 3051-3065.

King, S.D., 2005. Archean cratons and mantle dynamics. Earth Planet. Sci. Lett. 234, 1-14.

Kirby, S.H., 1985. Rock mechanics observations pertinent to the rheology of the continental lithosphere and the localization of strain along shear zones. Tectonophysics 119, 1-27.

Knoll, M., 2009. Modélisation multi-échelles de l'effet de la structure héritée sur la déformation des plaques continentales. Ph.D. thesis, Université de Montpellier 182 p.

Knoll, M., Tommasi, A., Logé, R., Signorelli, J., 2009. A multi-scale approach to model the anisotropic deformation of lithospheric plates. Geochem. Geophys. Geosyst. 10, Q08009. http://dx.doi.org/10.1029/2009GC002423.

Kobayashi, Y., 1974. Anisotropy of thermal diffusivity in olivine, pyroxene, and dunite. J. Phys. Earth 22, 359-373.

Kohlstedt, D.L., Zimmerman, M.E., 1996. Rheology of partially molten mantle rocks. Annu. Rev. Earth Planet. Sci. 24, 41-62.

Kopylova, M., Russell, J., Cookenboo, H., 1999. Petrology of peridotite and pyroxenite xenoliths from the Jericho kimberlite: implications for the thermal state of the mantle beneath the Slave craton, northern Canada. J. Petrol. 40, 79-104.

Kornprobst, J., 1969. Le massif ultrabasique des Beni Bouchera (Rif Interne, Maroc): Etude des péridotites de haute température et de haute pression, et des pyroxénolites, à grenat ou sans grenat, qui leur sont associées. Contrib. Mineral. Petrol. 23, 283-322.

Kosarev, G.L., Makeyeva, L.I., Vinnik, L.P., 1984. Anisotropy of the mantle inferred from observations of P to S converted waves. Geophys. J. R. Astron. Soc. 76, 209-220.
Kourim, F., Bodinier, J.-L., Alard, O., Bendaoud, A., Vauchez, A., Dautria, J.-M., 2014. Nature and evolution of the lithospheric mantle beneath the Hoggar swell (Algeria): a record from mantle xenoliths. J. Petrol. 55, 2249-2280.

Kourim, F., Vauchez, A., Bodinier, J.-L., Alard, O., Bendaoud, A., 2015. Subcontinental lithosphere reactivation beneath the Hoggar swell (Algeria): localized deformation, melt channeling and heat advection. Tectonophysics 650, 18-33. http://dx.doi.org/10. 1016/j.tecto.2014.1011.1012.

Kruckenberg, S.C., Tikoff, B., Toy, V.G., Newman, J., Young, L.I., 2013. Strain localization associated with channelized melt migration in upper lithospheric mantle: insights from the Twin Sisters ultramafic complex, Washington, USA. J. Struct. Geol. 50 $133-147$.

Kukkonen, I., Lauri, L., 2009. Modelling the thermal evolution of a collisional Precambrian orogen: high heat production migmatitic granites of southern Finland. Precambrian Res. 168, 233-246.

Kumazawa, M., Anderson, O.L., 1969. Elastic moduli, pressure derivatives, and temperature derivatives of single-crystal olivine and single-crystal forsterite. J. Geophys. Res. 74, 5961-5972.

Lawyer, L.A., Sclater, J.G., Meine, L., 1985. Mesozoic and Cenozoic reconstructions of the South Atlantic. Tectonophysics 114, 233-254

Le Roux, V., Bodinier, J.L., Tommasi, A., Alard, O., Dautria, J.M., Vauchez, A., Riches, A., 2007 The Lherz spinel-lherzolite: refertilized rather than pristine mantle. Earth Planet. Sci. Lett. 259, 599-612. http://dx.doi.org/10.1016/j.epsl.2007.05.026.

Le Roux, V., Tommasi, A., Vauchez, A., 2008. Feedback between melt percolation and deformation in an exhumed lithosphere-asthenosphere boundary. Earth Planet. Sci. Lett. 274, 401-413. http://dx.doi.org/10.1016/j.epsl.2008.07.053.

Lee, C.T.A., 2005. Trace element evidence for hydrous metasomatism at the base of the North American lithosphere and possible association with Laramide low-angle subduction. J. Geol. 113, 673-685.

Lee, C.T., Rudnick, R.L., 1999. Compositionally stratified cratonic lithosphere: petrology and geochemistry of peridotite xenoliths from the Labait Volcano, Tanzania. Proceedings of the 7th International Kimberlite Conference, pp. 503-552.

Lee, K.-H., Jian, Z., Karato, S.-I., 2002. A scanning electron microscope study of the effects of dynamic recrystallization on lattice preferred orientation in olivine. Tectonophysics 351, 331-341

Lenardic, A., Moresi, L.-N., Mühlhaus, H., 2003. Longevity and stability of cratonic lithosphere: insights from numerical simulations of coupled mantle convection and continental tectonics. J. Geophys. Res. 108, 2303. http://dx.doi.org/10.1029/ 2002JB001859.

Lenoir, X., Garrido, C., Bodinier, J.-L., Dautria, J.-M., Gervilla, F., 2001. The recrystallization front of the Ronda peridotite: evidence for melting and thermal erosion of lithospheric mantle beneath the Alboran basin. J. Petrol. 42, 141-158.

Leseane, K., Atekwana, E.A., Mickus, K.L., Abdelsalam, M.G., Shemang, E.M., Atekwana, E.A. 2015. Thermal perturbations beneath the incipient Okavango Rift Zone, northwest Botswana. J. Geophys. Res. 120. http://dx.doi.org/10.1002/2014JB011029.

Lesne, O., Calais, E., Déverchère, J., 1997. Finite-element modeling of crustal deformation in the Baikal rift zone: new insights into the passive-active rifting debate. Tectonophysics 289, 327-340.

Levin, V., Park, J., 1997. Crustal anisotropy in the Urals mountains foredeep from teleseismic receiver functions. Geophys. Res. Lett. 24, 1283-1286.

Linckens, J., Bruijn, R.H., Skemer, P., 2014. Dynamic recrystallization and phase mixing in experimentally deformed peridotite. Earth Planet. Sci. Lett. 388, 134-142.

Liu, L., Zoback, M.D., 1997. Lithospheric strength and intraplate seismicity in the New Madrid seismic zone. Tectonics 16, 585-595.

Mackwell, S.J., Kohlstedt, D.L., Paterson, M.S., 1985. Role of water in the deformation of olivine single-crystals. J. Geophys. Res. 90, 11,319-11,333.

Mainprice, D., 1997. Modelling anisotropic seismic properties of partially molten rocks found at mid-ocean ridges. Tectonophysics 279, 161-179.

Mainprice, D., 2007. Seismic anisotropy of the deep Earth from a mineral and rock physics perspective. In: Schubert, G. (Ed.), Treatise in GeophysicsMineral Physics vol. 2. Elsevier, pp. 437-491.

Mainprice, D., Ildefonse, B., 2009. Seismic anisotropy of subduction zone mineralscontribution of hydrous phases. Subduction Zone Geodynamics. Springer, pp. 63-84.

Mainprice, D., Hielscher, R., Schaeben, H., 2011. Calculating anisotropic physical properties from texture data using the MTEX open source package. In: Prior, D.J., Rutter E.H., Tatham, D.J. (Eds.), Deformation Mechanisms, Rheology and Tectonics: Microstructures. Special Publications, Mechanics and Anisotropy. Geol. Soc., London, pp. $175-192$.

Mareschal, M., Kellet, R.L., Kurtz, R.D., Ludden, J.N., Ji, S., Bailey, R.C., 1995. Archean cratonic roots, mantle shear zones and deep electrical anisotropy. Nature 375 134-137.

Medaris Jr., L., 1980. Petrogenesis of the Lien peridotite and associated eclogites, Almklovdalen, western Norway. Lithos 13, 339-353.

Mehl, L., Hacker, B.R., Hirth, G., Kelemen, P.B., 2003. Arc-parallel flow within the mantle wedge: evidence from the accreted Talkeetna arc, south central Alaska. J. Geophys. Res. 108, 2375. http://dx.doi.org/10.1029/2002JB002233.

Mei, S., Kohlstedt, D., 2000. Influence of water on plastic deformation of olivine aggregates: 2. Dislocation creep regime. J. Geophys. Res. 105, 21471-21481.

Menzies, M.A., Xu, Y., 1998. Geodynamics of the North China craton. Mantle Dynamics and Plate Interactions in East Asiapp. 155-165

Meqbel, N.M., Egbert, G.D., Wannamaker, P.E., Kelbert, A., Schultz, A., 2014. Deep electrical resistivity structure of the northwestern US derived from 3-D inversion of USArray magnetotelluric data. Earth Planet. Sci. Lett. 402, 290-304.

Michibayashi, K., Mainprice, D., 2004. The role of pre-existing mechanical anisotropy on shear zone development within oceanic lithospheric mantle: an example from the Oman pphiolite. J. Petrol. 45, 405-414. 
Michibayashi, K., Oohara, T., 2013. Olivine fabric evolution in a hydrated ductile shear zone at the Moho Transition Zone, Oman Ophiolite. Earth Planet. Sci. Lett. 377, 299-310.

Milani, E.J., Davison, I., 1988. Basement control and transfer tectonics in the RecôncavoTucano-Jatobá rift, Northeast Brazil. Tectonophysics 154, 41-70.

Mizukami, T., Wallis, S.R., Yamamoto, J., 2004. Natural examples of olivine lattice preferred orientation patterns with a flow-normal a-axis maximum. Nature 427, 432-436.

Mockel, J.R., 1969. The structural petrology of the garnet peridotite of Alpe Arami (Ticino, Switzerland). Leidse. Geol. Meded. 42, 61-130.

Molnar, P., Tapponnier, P., 1981. A possible dependence of tectonic strength on the age of the crust in Asia. Earth Planet. Sci. Lett. 52, 107-114.

Montagner, J.-P., 1998. Where can seismic anisotropy be detected in the Earth's mantle? In boundary layers.... Pure Appl. Geophys. 151, 233-256.

Montagner, J.-P., Kennett, B., 1996. How to reconcile body-wave and normal-mode reference Earth models. Geophys. J. Int. 125, 229-248.

Mookherjee, M., Mainprice, D., 2014. Unusually large shear wave anisotropy for chlorite in subduction zone settings. Geophys. Res. Lett. 41, 1506-1513.

Morency, C., Doin, M.-P., Dumoulin, C., 2002. Convective destabilization of a thickened continental lithosphere. Earth Planet. Sci. Lett. 202, 303-320.

Morgan, Z., Liang, Y., 2003. An experimental and numerical study of the kinetics of harzburgite reactive dissolution with applications to dunite dike formation. Earth Planet. Sci. Lett. 214, 59-74.

Nataf, H.C., Nakanishi, I., Anderson, D.L., 1984. Anisotropy and shear velocity heterogeneities in the upper mantle. Geophys. Res. Lett. 11, 109-112.

Neves, S.P., Tommasi, A., Vauchez, A., Hassani, R., 2008. Intraplate continental deformation: influence of a heat-producing layer in the lithospheric mantle. Earth Planet. Sci. Lett. 274, 392-400. http://dx.doi.org/10.1016/j.epsl.2008.07.040.

Newman, J., Lamb, W.M., Drury, M.R., Vissers, R.L.M., 1999. Deformation processes in a peridotite shear zone: reaction-softening by an $\mathrm{H} 2 \mathrm{O}$-deficient, continuous net transfe reaction. Tectonophysics 303, 193-222.

Nicolas, A., 1986. A melt extraction model based on structural studies in mantle peridotites. J. Petrol. 27, 999-1022.

Nicolas, A., Christensen, N.I., 1987. Formation of anisotropy in upper mantle peridotites a review. In: Fuchs, K., Froidevaux, C. (Eds.), Composition, Structure and Dynamics of the Lithosphere-Asthenosphere System. Am. Geophys. Un., Washington, D.C. pp. 111-123.

Nicolas, A., Boudier, F., Boullier, A.M., 1973. Mechanism of flow in naturally and experimentally deformed peridotites. Am. J. Sci. 273, 853-876.

Nicolas, A., Boudier, F., Montigny, R., 1987. Structure of Zabargad island and early rifting of the Red Sea. J. Geophys. Res. 92, 461-474.

Niida, K., 1984. Petrology of the Horoman ultramafic rocks in the Hidaka metamorphic belt, Hokkaido, Japan. 北海道大学理学部紀要 = Journal of the Faculty of Science, Hokkaido University. Series 4. Geol. Mineral. 21, 197-250.

Nyblade, A.A., Pollack, H.N., 1993. A global analysis of heat flow from Precambrian terrains: implications for the thermal structure of Archean and Proterozoic lithosphere. J. Geophys. Res. 98, 12207-12218.

O'Reilly, S.Y., Griffin, W., 2013. Mantle metasomatism. In: Harlov, D.E., Austrheim, H. (Eds.), Metasomatism and the Chemical Transformation of Rock. Springer pp. 471-533.

Obata, M., 1980. The Ronda peridotite: garnet-, spinel-, and plagioclase-lherzolite facies and the pt trajectories of a high-temperature mantle intrusion. J. Petrol. 21, 533-572.

Obata, M., Nagahara, N., 1987. Layering of alpine-type peridotite and the segregation of partial melt in the upper mantle. J. Geophys. Res. 92, 3467-3474.

Obayashi, M., Yoshimitsu, J., Nolet, G., Fukao, Y., Shiobara, H., Sugioka, H., Miyamachi, H. Gao, Y., 2013. Finite frequency whole mantle P wave tomography: improvement of subducted slab images. Geophys. Res. Lett. 40, 5652-5657.

Ohuchi, T., Nakamura, M., 2007. Grain growth in the forsterite-diopside system. Phys. Earth Planet. Inter. 160, 1-21

O'Reilly, S.Y., Griffin, W., 2000. Apatite in the mantle: implications for metasomatic processes and high heat production in Phanerozoic mantle. Lithos 53, 217-232.

Ozawa, K., 1988. Ultramafic tectonite of the Miyamori ophiolitic complex in the Kitakami Mountains, Northeast Japan: hydrous upper mantle in an island arc. Contrib. Mineral. Petrol. 99, 159-175.

Padilha, A.L., Vitorello, I., Pádua, M.B., Bologna, M.S., 2006. Lithospheric and sublithospheric anisotropy beneath central-southeastern Brazil constrained by long period magnetotelluric data. Phys. Earth Planet. Inter. 158, 190-209.

Padilha, A.L., Vitorello, I., Pádua, M.B., Bologna, M.S., 2014. Electromagnetic constraints for subduction zones beneath the northwest Borborema province: evidence for Neoproterozoic island arc-continent collision in northeast Brazil. Geology 42, 91-94.

Pearson, D. 1999. The age of continental roots. Dev. Geotectonics 24, 171-194.

Pearson, D., Canil, D., Shirey, S., 2007. Mantle samples included in volcanic rocks: xenoliths and diamonds. In: Turekian, K., Holland, H. (Eds.), Treatise of Geochemistry. The Mantle and Core vol. 2, pp. 171-275.

Pedersen, H., Debayle, E., Maupin, V., Group, P.L.W., 2013. Strong lateral variations of lithospheric mantle beneath cratons-example from the Baltic Shield. Earth Planet. Sci. Lett. 383, 164-172.

Peslier, A.H., Woodland, A.B., Bell, D.R., Lazarov, M., 2010. Olivine water contents in the continental lithosphere and the longevity of cratons. Nature 467, 78-81.

Peslier, A., Woodland, A., Bell, D., Lazarov, M., Lapen, T., 2012. Metasomatic control of water contents in the Kaapvaal cratonic mantle. Geochim. Cosmochim. Acta 97, 213-246.

Petit, C., Deverchere, J., 2006. Structure and evolution of the Baikal rift: a synthesis Geochem. Geophys. Geosyst. 7, Q11016. http://dx.doi.org/10.1029/2006GC001265.

Phakey, P., Dollinger, G., Christie, J., 1972. Transmission electron microscopy of experimentally deformed olivine crystals. In: Heard, H.C., Borg, I.Y., Carter, N.L., Rayleigh,
C. (Eds.). Flow and Fracture of Rocks. American Geophysical Union, Washington, DC, pp. 117-138.

Pham, V.N., Boyer, D., Nguyen, V.G., Nguyen, T.K.T., 1995. Proprietes electriques et structure profonde de la zone de faille du Fleuve Rouge au Nord Viet-Nam d'apres les resultats de sondage magnetotellurique. C. R. Acad. Sci. II Sci. Terre Planetes 320, $181-188$.

Piccardo, G., Zanetti, A., Müntener, O., 2007. Melt/peridotite interaction in the Southern Lanzo peridotite: field, textural and geochemical evidence. Lithos 94, 181-209.

Platt, J., Behr, W., 2011. Lithospheric shear zones as constant stress experiments. Geology 39, 127-130

Poe, B.T., Romano, C., Nestola, F., Smyth, J.R., 2010. Electrical conductivity anisotropy of dry and hydrous olivine at 8 GPa. Phys. Earth Planet. Inter. 181, 103-111.

Poirier, J.P., 1980. Shear localisation and shear instability in materials in the ductile field. J. Struct. Geol. 2, 135-142.

Poirier, J.P., Nicolas, A., 1975. Deformation-induced recrystallization due to progressive misorientation of subgrains, with special reference to mantle peridotites. J. Geol. 83, $707-720$.

Pommier, A., Garnero, E., 2014. Petrology-based modeling of mantle melt electrical conductivity and joint interpretation of electromagnetic and seismic results. J. Geophys. Res. 119, 4001-4016.

Pommier, A., Leinenweber, K., Kohlstedt, D.L., Qi, C., Garnero, E.J., Mackwell, S.J., Tyburczy, J.A., 2015. Experimental constraints on the electrical anisotropy of the lithosphereasthenosphere system. Nature 522, 202-206.

Pous, J., Munoz, G., Heise, W., Melgarejo, J.C., Quesada, C., 2004. Electromagnetic imaging of Variscan crustal structures in SW Iberia: the role of interconnected graphite. Earth Planet. Sci. Lett. 217, 435-450.

Powell, C.M.A., Roots, S.R., Veewers, J.J., 1988. Pre-breakup continental extension in East Gondwanaland and the early opening of the eastern Indian Ocean. Tectonophysics $155,261-283$.

Précigout, J., Hirth, G., 2014. B-type olivine fabric induced by grain boundary sliding. Earth Planet. Sci. Lett. 395, 231-240.

Prinzhofer, A., Nicolas, A., 1980. The Bogota Peninsula, New Caledonia: a possible oceanic transform fault. J. Geol. 88, 387-398.

Prinzhofer, A., Nicolas, A., Cassard, D., Moutte, J., Leblanc, M., Paris, J., Rabinovitch, M., 1980. Structures in the New Caledonia peridotites-gabbros: implications for oceanic mantle and crust. Tectonophysics 69, 85-112.

Quick, J.E., 1982. The origin and significance of large, tabular dunite bodies in the Trinity Peridotite, northern California. Contrib. Mineral. Petrol. 78, 413-422.

Raffone, N., Chazot, G., Pin, C., Vannucci, R., Zanetti, A., 2009. Metasomatism in the lithospheric mantle beneath Middle Atlas (Morocco) and the origin of Fe- and Mg-rich wehrlites. J. Petrol. 50, 197-249.

Rampone, E., Morten, L., 2001. Records of crustal metasomatism in the garnet peridotites of the Ulten Zone (Upper Austroalpine, Eastern Alps). J. Petrol. 42, 207-219.

Reston, T.J., 1993. Evidence for extensional shear zones in the mantle, offshore Britain, and their implications for the extension of the continental lithosphere. Tectonics 12 , 492-506.

Reston, T.J., 1990. Mantle shear zones and the evolution of the North Sea basin. Geology $18,272-275$

Ritsema, J., Deuss, A., van Heijst, H.J., Woodhouse, J.H., 2011. S40RTS: a degree-40 shearvelocity model for the mantle from new Rayleigh wave dispersion, teleseismic traveltime and normal-mode splitting function measurements. Geophys. J. Int. 184, $1223-1236$

Rollett, A., Humphreys, F., Rohrer, G.S., Hatherly, M., 2004. Recrystallization and Related Annealing Phenomena. Elsevier.

Rozel, A., Ricard, Y., Bercovici, D., 2011. A thermodynamically self-consistent damage equation for grain size evolution during dynamic recrystallization. Geophys. J. Int. $184,719-728$.

Rümpker, G., Ryberg, T., 2000. New "Fresnel-Zone" estimates for shear-wave splitting observations from finite-difference modeling. Geophys. Res. Lett. 27, 2005-2008.

Rümpker, G., Tommasi, A., Kendall, J.-M., 1999. Numerical simulations of depthdependent anisotropy and frequency-dependent wave propagation effects. J. Geophys. Res. 104, 23,141-23,153.

Rychert, C.A., Shearer, P.M., 2009. A global view of the lithosphere-asthenosphere boundary. Science $324,495-498$.

Santos, A.C., Padilha, A.L., Fuck, R.A., Pires, A.C., Vitorello, I., Pádua, M.B., 2014. Deep structure of a stretched lithosphere: magnetotelluric imaging of the southeastern Borborema province, NE Brazil. Tectonophysics 610, 39-50.

Savage, M.K., 1999. Seismic anisotropy and mantle deformation: what have we learned from shear wave splitting? Rev. Geophys. 37, 65-106.

Scherwath, M., Melhuish, A., Stern, T., Molnar, P., 2002. Pn anisotropy and distributed upper mantle deformation associated with a continental transform fault. Geophys. Res. Lett. 29, 1175. http://dx.doi.org/10.1029/2001GL014179.

Schettino, A., Scotese, C., 2002. Global kinematic constraints to the tectonic history of the Mediterranean region and surrounding areas during the Jurassic and Cretaceous. J. Virtual Explor. 8, 145-160.

Schettino, A., Turco, E., 2009. Breakup of Pangaea and plate kinematics of the central Atlantic and Atlas regions. Geophys. J. Int. 178, 1078-1097.

Schumacher, M.E., 2002. Upper Rhine Graben: role of preexisting structures during rift evolution. Tectonics 21, 1-17.

Sen, G., 1988. Petrogenesis of spinel lherzolite and pyroxenite suite xenoliths from the Koolau Shield, Oahu, Hawaii; implications for petrology of the post-eruptive lithosphere beneath Oahu. Contrib. Mineral. Petrol. 100, 61-91.

Sénéchal, G., Rondenay, S., Mareschal, M., Guilbert, J., Poupinet, G., 1996. Seismic and electrical anisotropies in the lithosphere across the Grenville Front, Canada. Geophys. Res. Lett. $23,2255-2258$. 
Sheehan, A.F., Torre, T.L., Monsalve, G., Abers, G.A., Hacker, B.R., 2014. Physical state of Himalayan crust and uppermost mantle: constraints from seismic attenuation and velocity tomography. J. Geophys. Res. 119, 567-580.

Shervais, J., 1978. Ultramafics and mafics layers in the alpine-type lherzolite massif at Balmuccia, NW Italy. Memorie di scienze geologiche. Università di Padova, Padova, pp. $135-145$

Shito, A., Suetsugu, D., Furumura, T., Sugioka, H., Ito, A., 2013. Small-scale heterogeneities in the oceanic lithosphere inferred from guided waves. Geophys. Res. Lett. 40, $1708-1712$.

Sifré, D., Gardés, E., Massuyeau, M., Hashim, L., Hier-Majumder, S., Gaillard, F., 2014. Electrical conductivity during incipient melting in the oceanic low-velocity zone. Nature 509, 81-85.

Silver, P.G., Chan, W., 1988. Implications for continental structure and evolution from seismic anisotropy. Nature 335, 34-39.

Silver, P.G., Chan, W.W., 1991. Shear wave splitting and subcontinental mantle deformation. J. Geophys. Res. 96, 16429-16454.

Silver, P.G., Savage, M.K., 1994. The interpretation of shear wave splitting parameters in the presence of two anisotropic layers. Geophys. J. Int. 119, 949-963.

Silver, P.G., Mainprice, D., Ben Ismail, W., Tommasi, A., Barruol, G., 1999. Mantle structural geology from seismic anisotropy. In: Fei, Y., Bertka, C.M., Mysen, B.O. (Eds.), Mantle Petrology: Field Observations and High Pressure Experimentation: A Tribute to Francis R. (Joe) Boyd. The Geochemical Society, Washington, pp. 79-103.

Silver, P.G., Gao, S.S., Liu, K.H., 2001. Mantle deformation beneath Southern Africa. Geophys. Res. Lett. 28, 2493-2496.

Simmons, N.A., Myers, S.C., Johannesson, G., Matzel, E., 2012. LLNL-G3Dv3: global P wave tomography model for improved regional and teleseismic travel time prediction. J. Geophys. Res. 117, B10302. http://dx.doi.org/10.1029/2012JB009525.

Skemer, P., Karato, S.I., 2008. Sheared lherzolite xenoliths revisited. J. Geophys. Res. 113, B07205. http://dx.doi.org/10.1029/2007JB005286.

Skemer, P., Katayama, I., Karato, S.-i., 2006. Deformation fabrics of the Cima di Gagnone peridotite massif, Central Alps, Switzerland: evidence of deformation at low temperatures in the presence of water. Contrib. Mineral. Petrol. 152, 43-51.

Smith, G.P., Ekström, G., 1999. A global study of Pn anisotropy beneath continents. J. Geophys. Res. 104, 963-980.

Snyder, D., Berman, R., Kendall, J.-M., Sanborn-Barrie, M., 2013. Seismic anisotropy and mantle structure of the Rae craton, central Canada, from joint interpretation of SKS splitting and receiver functions. Precambrian Res. 232, 189-208.

Sodoudi, F., Yuan, X., Kind, R., Lebedev, S., Adam, J.M.C., Kästle, E., Tilmann, F., 2013. Seismic evidence for stratification in composition and anisotropic fabric within the thick lithosphere of Kalahari Craton. Geochem. Geophys. Geosyst. 14, 5393-5412.

Soustelle, V., Tommasi, A., 2010. Seismic properties of the supra-subduction mantle: constraints from peridotite xenoliths from the Avacha volcano, southern Kamchatka. Geophys. Res. Lett. 37, L13307. http://dx.doi.org/10.1029/2010GL043450.

Soustelle, V., Tommasi, A., Bodinier, J.L., Vauchez, A., Garrido, C.J.M., 2009. Deformation and reactive melt transport in the lithospheric mantle above a partial melting domain (Ronda peridotite massif, Spain). J. Petrol. 50, 1235-1266. http://dx.doi.org/10.1093/ petrology/egp1032.

Soustelle, V., Tommasi, A., Demouchy, S., Franz, L., 2013. Melt-rock interactions, deformation, hydration and seismic properties in the sub-arc lithospheric mantle inferred from xenoliths from seamounts near Lihir, Papua New Guinea. Tectonophysics 608 , 330-345.

Štípská, P., Schulmann, K., Thompson, A., Ježek, J., Kröner, A., 2001. Thermo-mechanical role of a Cambro-Ordovician paleorift during the Variscan collision: the NE margin of the Bohemian Massif. Tectonophysics 332, 239-253.

Strating, E.H., Rampone, E., Piccardo, G., Drury, M., Vissers, R., 1993. Subsolidus emplacement of mantle peridotites during incipient oceanic rifting and opening of the Mesozoic Tethys (Voltri Massif, NW Italy). J. Petrol. 34, 901-927.

Suhr, G., 1993. Evaluation of upper mantle microstructures in the Table Mountain massif (Bay of Islands Ophiolite). J. Struct. Geol. 15, 1273-1292.

Suhr, G., Hellebrand, E., Snow, J.E., Seck, H.A., Hofmann, A.W., 2003. Significance of large, refractory dunite bodies in the upper mantle of the Bay of Islands Ophiolite. Geochem. Geophys. Geosyst. 4, 8605. http://dx.doi.org/10.1029/2001GC000277.

Sundberg, M., Cooper, R.F., 2008. Crystallographic preferred orientation produced by diffusional creep of harzburgite: effects of chemical interactions among phases during plastic flow. J. Geophys. Res. 113, B12208. http://dx.doi.org/10.1029/2008JB005618.

Takei, Y., Holtzman, B.K., 2009. Viscous constitutive relations of solid-liquid composites in terms of grain boundary contiguity: 3. Causes and consequences of viscous anisotropy. J. Geophys. Res. 114, B06207. http://dx.doi.org/10.1029/2008JB005852.

Tasaka, M., Hiraga, T., Zimmerman, M.E., 2013. Influence of mineral fraction on the rheological properties of forsterite + enstatite during grain-size-sensitive creep: 2. Deformation experiments. J. Geophys. Res. 118, 3991-4012.

Teanby, N.A., Kenda, N.A., Kendall, J.M., van der Baan, M., 2004. Automation of shear-wave splitting measurements using cluster analysis. Bull. Seismol. Soc. Am. 94, 453-463.

Tesauro, M., Kaban, M.K., Mooney, W.D., Cloetingh, S.A.P.L., 2014. Density, temperature, and composition of the North American lithosphere: new insights from a joint analysis of seismic, gravity, and mineral physics data. 2: Thermal and compositional model of the upper mantle. Geochem. Geophys. Geosyst. 15, 4808-4830. http://dx. doi.org/10.1002/2014GC005484.

Thybo, H., Perchuc, E., 1997. The seismic 8 degrees discontinuity and partial melting in continental mantle. Science 275, 1626-1629.

Tikoff, B., Larson, C.E., Newman, J., Little, T., 2010. Field-based constraints on finite strain and rheology of the lithospheric mantle, Twin Sisters, Washington. Lithosphere 2 , 418-422.

Titus, S.J., Medaris, J.L.G., Wang, H.F., Tikoff, B., 2007. Continuation of the San Andreas fault system into the upper mantle: evidence from spinel peridotite xenoliths in the Coyote Lake basalt, central California. Tectonophysics 429, 1-20.
Titus, S.J., Maes, S.M., Benford, B., Ferré, E.C., Tikoff, B., 2011. Fabric development in the mantle section of a paleotransform fault and its effect on ophiolite obduction, New Caledonia. Lithosphere 3, 221-244.

Tommasi, A., Ishikawa, A., 2014. Microstructures, composition, and seismic properties of the Ontong Java Plateau mantle root. Geochem. Geophys. Geosyst. 15, 4547-4569. http://dx.doi.org/10.1002/2014GC005452.

Tommasi, A., Vauchez, A., 1997. Complex tectono-metamorphic patterns in continental collision zones: the role of intraplate rheological heterogeneities. Tectonophysics 279, 323-350.

Tommasi, A., Vauchez, A., 2001. Continental rifting parallel to ancient collisional belts: an effect of the mechanical anisotropy of the lithospheric mantle. Earth Planet. Sci. Lett. $185,199-210$.

Tommasi, A., Vauchez, A., Daudré, B., 1995. Initiation and propagation of shear zones in a heterogeneous continental lithosphere. J. Geophys. Res. 100, 22,083-22,101.

Tommasi, A., Tikoff, B., Vauchez, A., 1999. Upper mantle tectonics: three-dimensional deformation, olivine crystallographic fabrics and seismic properties. Earth Planet. Sci. Lett. 168, 173-186.

Tommasi, A., Mainprice, D., Canova, G., Chastel, Y., 2000. Viscoplastic self-consistent and equilibrium-based modeling of olivine lattice preferred orientations. Implications for upper mantle seismic anisotropy. J. Geophys. Res. 105, 7893-7908.

Tommasi, A., Gibert, B., Seipold, U., Mainprice, D., 2001. Anisotropy of thermal diffusivity in the upper mantle. Nature 411, 783-787.

Tommasi, A., Godard, M., Coromina, G., Dautria, J.-M., Barsczus, H., 2004. Seismic anisotropy and compositionally induced velocity anomalies in the lithosphere above mantle plumes: a petrological and microstructural study of mantle xenoliths from French Polynesia. Earth Planet. Sci. Lett. 227, 539-556.

Tommasi, A., Vauchez, A., Godard, M., Belley, F., 2006. Deformation and melt transport in a highly depleted peridotite massif from the Canadian Cordillera: implications to seismic anisotropy above subduction zones. Earth Planet. Sci. Lett. 252, 245-259. http://dx.doi.org/10.1016/j.epsl.2006.09.042.

Tommasi, A., Vauchez, A., Ionov, D.A., 2008. Deformation, static recrystallization, and reactive melt transport in shallow subcontinental mantle xenoliths (Tok Cenozoic volcanic field, SE Siberia). Earth Planet. Sci. Lett. 272, 65-77. http://dx.doi.org/10.1016/j. epsl.2008.04.020.

Tommasi, A., Knoll, M., Vauchez, A., Signorelli, J., Thoraval, C., Logé, R., 2009. Structural reactivation in plate tectonics controlled by olivine crystal anisotropy. Nat. Geosci. 2 423-427. http://dx.doi.org/10.1038/NGEO528.

Toramaru, A., Takazawa, E., Morishita, T., Matsukage, K., 2001. Model of layering formation in a mantle peridotite (Horoman, Hokkaido, Japan). Earth Planet. Sci. Lett. 185, 299-313.

Toriumi, M., 1982. Grain boundary migration in olivine at atmospheric pressure. Phys Earth Planet. Inter. 30, 26-35.

Toriumi, M., Karato, S., 1985. Preferred orientation development of dynamically recrystallized olivine during high-temperature deformation. J. Geol. 93, 407-417.

Toy, V.G., Newman, J., Lamb, W., Tikoff, B., 2010. The role of pyroxenites in formation of shear instabilities in the mantle: evidence from an ultramafic ultramylonite, Twin Sisters Massif, Washington. J. Petrol. 51, 55-80.

Trampert, J., Van Der Hilst, R.D., 2005. Towards a quantitative interpretation of global seismic tomography. Earth's Deep Mantle: Structure, Composition, and Evolution. Geophysical Monograph Series 160, pp. 47-62.

Van der Wal, D., Vissers, R.L.M., 1996. Structural petrology of the Ronda peridotite, SW Spain: deformation history. J. Petrol. 37, 23-43.

Vauchez, A., Tommasi, A., Egydio da Silva, M., 1994. Self-indentation of a heterogeneous continental lithosphere. Geology 22, 967-970.

Vauchez, A., Garrido, C., 2001. Seismic properties of an asthenospherized lithospheric mantle: constraints from lattice preferred orientations in peridotite from the Rond massif. Earth Planet. Sci. Lett. 192, 235-249.

Vauchez, A., Nicolas, A., 1991. Mountain building: strike-parallel displacements and mantle anisotropy. Tectonophysics $185,183-201$

Vauchez, A., Pacheco-Neves, S., Caby, R., Corsini, M., Egydio-Silva, M., Arthaud, M., Amaro, V., 1995. The Borborema shear zone system. J. S. Am. Earth Sci. 8, 247-266.

Vauchez, A., Tommasi, A., Barruol, G., 1998. Rheological heterogeneity, mechanical anisotropy, and tectonics of the continental lithosphere. Tectonophysics 296, 61-86.

Vauchez, A., Tommasi, A., Barruol, G., Maumus, J., 2000. Upper mantle deformation and seismic anisotropy in continental rifts. Phys. Chem. Earth A 25, 111-117.

Vauchez, A., Dineur, F., Rudnick, R., 2005. Microstructure, texture and seismic anisotropy of the lithospheric mantle above a mantle plume: insights from the Labait volcano xenoliths (Tanzania). Earth Planet. Sci. Lett. 232, 295-314.

Vauchez, A., Tommasi, A., Mainprice, D., 2012. Faults (shear zones) in the Earth's mantle Tectonophysics 558, 1-27.

Vilotte, J.-P., Madariaga, R., Daignières, M., Zienkiewicz, O., 1984. The role of a heterogeneous inclusion during continental collision. Phys. Earth Planet. Inter. 36, 236-259.

Vinnik, L.P., Kosarev, G.L., Makeyeva, L.I., 1984. Anisotropy of the lithosphere from the observations of SKS and SKKS. Proc. Acad. Sci. USSR 78, 1335-1339 (in Russian).

Vinnik, L., Aleshin, I., Kiselev, S., Kosarev, G., Makeyeva, L., 2007. Depth localized azimuthal anisotropy from SKS and P receiver functions: The Tien Shan. Geophys. J. Int. 169 1289-1299.

Vissers, R., Drury, M., Hoogerduijn, E., Spiers, C., Van der Wal, D., 1995. Mantle shear zones and their effect on lithosphere strength during continental breakup. Tectonophysics 249, 155-171.

Vissers, R.L.M., Drury, M.R., Newman, J., Vlirvoert, T.F., 1997. Mylonitic deformation in upper mantle peridotites of the North Pyrenean Zone (France): implications for strength and strain localization in the lithosphere. Tectonophysics 279, 303-325.

Vitorello, I., Pollack, H.N., 1980. On the variation of continental heat flow with age and the thermal evolution of continents. J. Geophys. Res. 85, 983-995. 
Walpole, J., Wookey, J., Masters, G., Kendall, J., 2014. A uniformly processed data set of SKS shear wave splitting measurements: a global investigation of upper mantle anisotropy beneath seismic stations. Geochem. Geophys. Geosyst. 15, 1991-2010. http://dx.doi.org/10.1002/2014GC005278.

Wang, D., Mookherjee, M., Xu, Y., Karato, S.-i., 2006. The effect of water on the electrical conductivity of olivine. Nature 443, 977-980.

Wang, D., Karato, S.i., Jiang, Z., 2013a. An experimental study of the influence of graphite on the electrical conductivity of olivine aggregates. Geophys. Res. Lett. 40, 2028-2032.

Wang, Y., Zhang, J., Shi, F., 2013b. The origin and geophysical implications of a weak C-type olivine fabric in the Xugou ultrahigh pressure garnet peridotite. Earth Planet. Sci. Lett. $376,63-73$.

Wannamaker, P.E., Chave, A.D., Booker, J.R., Jones, A.G., Filloux, J.H., Ogawa, Y., Unsworth, M., Tarits, P., Evans, R., 1996. Magnetotelluric experiment probes deep physical state of southeastern U.S. Eos 77, 329-333.

Warren, J.M., Hirth, G., 2006. Grain size sensitive deformation mechanisms in naturally deformed peridotites. Earth Planet. Sci. Lett. 248, 423-435.

Warren, J.M., Hirth, G., Kelemen, P.B., 2008. Evolution of olivine lattice preferred orientation during simple shear in the mantle. Earth Planet. Sci. Lett. 272, 501-512.

White, S., Burrows, S., Carreras, J., Shaw, N., Humphreys, F., 1980. On mylonites in ductile shear zones. J. Struct. Geol. 2, 175-187.

Whittington, A.G., Hofmeister, A.M., Nabelek, P.I, 2009. Temperature-dependent therma diffusivity of the Earth's crust and implications for magmatism. Nature 458, 319-321.

Wilson, J.T., 1966. Did the Atlantic close and then re-open? Nature 211, 676-681.

Wittlinger, G., Farra, V., 2007. Converted waves reveal a thick and layered tectosphere beneath the Kalahari super-craton. Earth Planet. Sci. Lett. 254, 404-415.

Wuestefeld, A., Barruol, G., Bokelmann, G., Montagner, J.-P., 2009. Identifying global seismic anisotropy patterns by correlating shear-wave splitting and surface waves data. Phys. Earth Planet. Inter. 176, 198-212. http://dx.doi.org/10.1016/j.pepi.2009.05.06 (database available online at http://splitting.gm.univ-montp1012.fr/DB).
Xu, Y.-G., Ross, J.V., Mercier, J.-C.C., 1993. The upper mantle beneath the continental rift of Tanlu, Eastern China: evidence for the intra-lithospheric shear zones. Tectonophysics 225, 337-360.

Xu, Z., Wang, Q., Ji, S., Chen, J., Zeng, L., Yang, J., Chen, F., Liang, F., Wenk, H.-R., 2006. Petrofabrics and seismic properties of garnet peridotite from the UHP Sulu terrane (China): implications for olivine deformation mechanism in a cold and dry subducting continental slab. Tectonophysics 421, 111-127.

Yin, Y, Unsworth, M., Liddell, M. Pana, D. Craven, J A 2014. Electrical resistivity structure of the Great Slave Lake shear zone, northwest Canada: implications for tectonic history. Geophys. J. Int. 199, 178-199.

Yoshino, T., Katsura, T., 2013. Electrical conductivity of mantle minerals: role of water in conductivity anomalies. Annu. Rev. Earth Planet. Sci. 41, 605-628.

Yoshino, T., Matsuzaki, T., Shatskiy, A., Katsura, T., 2009. The effect of water on the electrical conductivity of olivine aggregates and its implications for the electrical structure of the upper mantle. Earth Planet. Sci. Lett. 288, 291-300.

Yuan, H., Romanowicz, B., 2010. Lithospheric layering in the North American craton. Nature 466, 1063-1068.

Zaffarana, C., Tommasi, A., Vauchez, A., Grégoire, M., 2014. Microstructures and seismic properties of south Patagonian mantle xenoliths (Gobernador Gregores and Pali Aike). Tectonophysics 621, 175-197.

Zanetti, A., Mazzucchelli, M., Rivalenti, G., Vannucci, R., 1999. The Finero phlogopiteperidotite massif: an example of subduction-related metasomatism. Contrib. Mineral. Petrol. 134, 107-122.

Zerka, M., Cottin, J.-Y., Grégoire, M., Lorand, J.-P., Megartsie, M.H., Midounf, M., 2002. Les xénolites ultramafiques du volcanisme alcalin quaternaire d'Oranie (Tell, Algérie occidentale), témoins d'une lithosphère cisaillée et enrichie. C.R. Acad. Sci., Ser. IIa: Sci. Terre Planets 334, 387-394.

Zhang, S., Karato, S., 1995. Lattice preferred orientation of olivine aggregates in simple shear. Nature 375, 774-777. 